CARLOS ADALBERTO MARTINS

\title{
VIOLÊNCIA, EDUCAÇÃO, SUBCIDADANIA E DEMOCRACIA NA PERIFERIA DA GRANDE METRÓPOLE
}

UNIVERSIDADE DE SÃO PAULO

(USP) SÃO PAULO

ANO 2007 


\title{
CARLOS ADALBERTO MARTINS
}

\section{VIOLÊNCIA, EDUCAÇÃO, SUBCIDADANIA E DEMOCRACIA NA PERIFERIA DA GRANDE METRÓPOLE.}

\author{
Dissertação apresentada à Universidade de \\ São Paulo como requisito parcial para a obtenção \\ do título de mestre em Geografia Humana. \\ Orientador Professor Dr. José Willian Vesentini.
}

\section{SÃO PAULO}

2007 
“Alguns juízes são absolutamente incorruptíveis. Ninguém consegue induzi-los a fazer justiça," Bertold Brecht 
Está obra é dedicada a todos os moradores da periferia de São Paulo, pois foi pensando neles que realizei este trabalho. 


\section{AGRADECIMENTOS}

Ao meu Orientador, Professor Dr. José Willian Vesentini,

Professora Dr ${ }^{\mathrm{a}}$ Nidia Nacib Pontuschka,

Professora Dr ${ }^{\mathrm{a}}$ Amélia Luisa Damiani

e ao Professor Dr. Lucio Kowaric,

que tornaram possível a realização deste trabalho. 


\section{APRESENTAÇÃO}

No momento do golpe militar de 1964, eu cursava a então segunda série do ginásio, que seria hoje a sexta série do ensino fundamental. Naqueles idos tempos, a militância política começava cedo. No ginásio tomava-se partido e participava-se de discussões políticas.

Havia alguns professores que realizavam um discurso antiimperialista (o imperialismo norte americano era um termo muito em moda e também muito contestado na época) e um forte discurso nacionalista, que acabava por levar os alunos a terem uma postura engajada. O principal valor que se aprendia na época era o de que nada era mais importante do que a liberdade. A instituição escolar trabalhava continuamente dois valores, que eram introjectados como dois sentimentos fortes nas crianças e adolescentes: amor à pátria e à liberdade.

Alguns professores foram presos, entre eles um professor de História, que mais tarde veio a ser meu professor de História Econômica, no curso de Ciências Sociais. Estes fatos desde cedo fizeram com que eu acreditasse que a redemocratização ou, nos meus termos, a liberdade, passaria necessariamente pela educação e, querendo participar da História para dela não ser apenas um produto, optei por ser professor.

Aos 16 anos já era engajado em movimentos estudantis de resistência à ditadura e convivia com muitos militantes do Partido Comunista do Brasil, tendo uma postura marxista de análise do processo histórico. Independentemente de qualquer formação, a ditadura representava a supressão da liberdade e meu objetivo permanente, bem como dos meus colegas, era derrubar o regime. Muitos enveredaram pelo caminho da luta armada, coisa em que eu não acreditava, porque não havia chance alguma, sequer de que o país soubesse que estava havendo luta. 
Nos meados da década de 70 do século passado já havia concluído a minha licenciatura em Ribeirão Preto e vislumbrei a possibilidade de lecionar aqui na cidade de São Paulo. Acabei atuando na periferia, em um espaço onde pude constatar uma total ausência do Estado, enquanto ações efetivas de governo, no que tange à promoção do bem estar social e de garantia de direitos mínimos do cidadão trabalhador.

Para lecionar as disciplinas nas quais eu era habilitado (Educação Moral e Cívica e Organização Social e Política do Brasil, Geografia e História), era necessário Atestado de Antecedentes Políticos e Sociais, expedido pela Delegacia de Ordem Política e Social (DOPS). O regime autoritário não permitia nenhuma crítica ou contestação e muito menos formação de opinião, o professor deveria ser "orgânico", reproduzir a visão de mundo da ditadura e a simples formação ou graduação na área já bastava para ser rotulado como tendencioso. $\mathrm{O}$ atestado era um dos instrumentos utilizados para controlar o professor, mas havia outros, como o de colocar prepostos ou simpatizantes do regime em sala de aula, matriculados como alunos, para delatar professores que contestassem o regime, que eram presos e torturados.

Era neste contexto que eu atuava, em que a maior parte da população escolar era composta por migrantes nordestinos e seus descendentes, que não tinha noção do que realmente acontecia no Brasil. A periferia era um espaço carente de tudo e eu acreditava que com o fim do regime militar seria possível organizar a sociedade e atuar objetivamente na transformação da realidade.

Apesar do quadro de exclusão social facilmente constatado pelo conjunto de carência em todas as áreas que a região apresentava, o cotidiano das pessoas em consonância com a cultura da região estava voltado para assegurar condições materiais mínimas de sobrevivência, o que se fazia através de um emprego, que o Estado, cujo sinônimo para elas era governo, como o grande provedor de todos, segundo a maioria, estava fazendo. Ao 
longo do tempo aprendi que nesse quadro absolutamente adverso, falar em liberdade era uma abstração, pois a prioridade era a sobrevivência.

O regime militar acabou, a exclusão social continuou e as dificuldades agravaram-se. Apesar da fala oficial, o exercício da cidadania e a prática da democracia continuou algo distante, a democracia efetivamente participativa, parece não ter chegado à periferia e, apesar dos diplomas legais colocando a cidadania como um dos objetivos prioritários da educação, a minha vivência como professor demonstra que as instituições escolares ainda não colocaram tal objetivo em prática.

Como cidadão da periferia, por prática, por vivência, eu sei que é muito difícil e para muitos é impossível o exercício da cidadania e a prática da democracia nessas regiões, devido à ausência de ações efetivas do Estado ou do governo.

Assim, há anos me perguntava: é possível um projeto sistemático de educação para o difícil exercício da cidadania e prática da democracia na periferia de uma grande metrópole e se tal trabalho daria retorno objetivo? Como assistente de direção de um colégio particular na periferia, com liberdade para ação e coordenação pedagógica, procurei responder à minha pergunta e traçar diretrizes para uma educação sistemática dirigida para a construção da cidadania e prática democrática nesse ambiente social e procurei sempre ver como as instituições escolares tratam a questão na região, o que me levou a pesquisar outras instituições. No meu caso particular pude constatar que as barreiras são imensas e que transpô-las requerer além de políticas públicas bem definidas, um engajamento de todos os participantes do processo educacional, o que nem sempre ocorre. Mas para que a educação tenha repercussão como um todo na periferia, capaz de representar uma mudança significativa na organização do espaço periférico é necessário mais que uma ou outra simples instituição escolar trabalhando o tema proposto e foi este projeto que motivou a realização do mestrado em Geografia Humana, dirigida para a compreensão e organização 
do espaço uma vez que ela compõe o quadro de disciplinas básicas de formação de cidadania.

\subsection{AVALIAÇÃO DE EXPERIÊNCIA}

Para a consecução do objetivo proposto, cursei as seguintes disciplinas:

1. Espaço, Reprodução e Cotidiano, com a professora Amélia Luisa Damiani;

2. Ensino e Aprendizagem da Geografia e as Práticas Interdisciplinares, com a professora Nídia Nacib Pontuschka;

3. Movimentos Sociais, Sociedade Civil e (Sub)Cidadania: Teorias e Realidades, com o professor Lúcio Kowarick.

Avalio a experiência vivida na pos graduação da seguinte forma: com os estudos sobre o Espaço, Reprodução e Cotidiano, foi possível obter uma clara percepção da realidade cotidiana da metrópole que se pretendia estudar, facilitando a formulação de idéias sobre a realidade estudada.

Com o Ensino e Aprendizagem da Geografia, houve uma rica experiência de trabalho de campo com realização de um trabalho de Estudo do Meio com a professora Nídia, que propiciou uma ferramenta de extrema importância para o trabalho de pesquisa realizado e sobretudo na formulação das entrevistas. Finalmente, com a disciplina do professor Lúcio Kowarick, foi possível formular a contextualização teórica que possibilitou uma clara imagem da realidade periférica indo de encontro à temática do estudo, sobretudo, da questão da subcidadania enfocada no presente trabalho.

Para finalizar, contamos com a segura orientação do Professor Dr. José William Vesentini, que indicou o caminho a ser percorrido e como percorrê-lo, além de indicar obra e autor que acabaram sendo referências obrigatórias, pelo trabalho que já desenvolveram sobre o tema proposto. 


\section{SUMÁRIO}

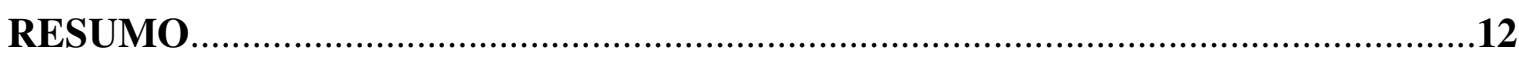

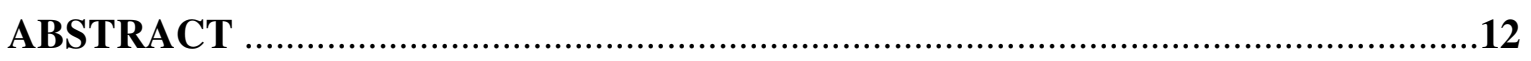

INTRODUÇÃ

1.CAPÍTULO - PERIFERIA, VIOLÊNCIA, EXCLUSÃO E DESEMPREGO..........25

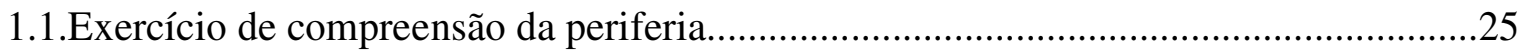

1.2. O cenário atualizado da periferia da maior metrópole do Brasil...................................30

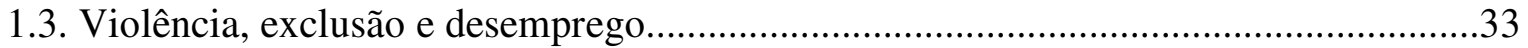

2.CAPÍTULO - CARACTERIZAÇÃO DAS ESCOLAS ............................................ 37

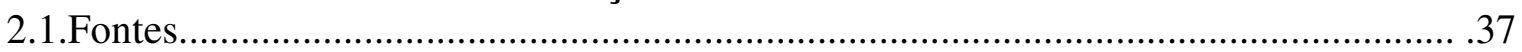

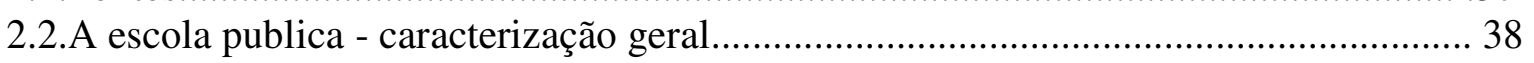

2.3.Diretrizes da proposta de educação para a cidadania da escola pública........................ 40

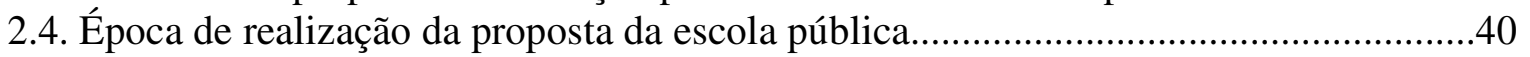

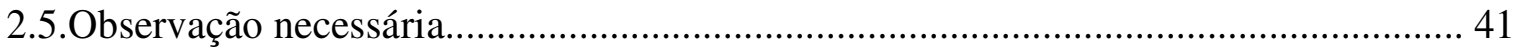

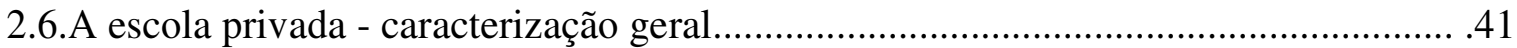

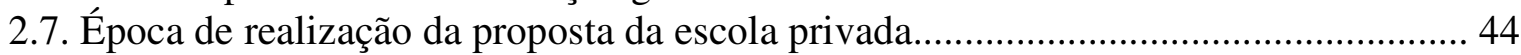

2.8. Diretrizes da proposta de educação para a cidadania da escola privada......................... 45

3.CAPÍTULO - OS ATORES FALAM DE SUA EXPERIÊNCIA .............................. 47

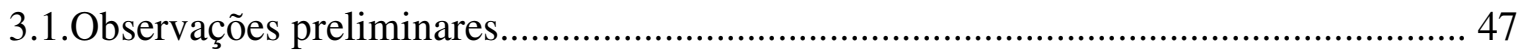

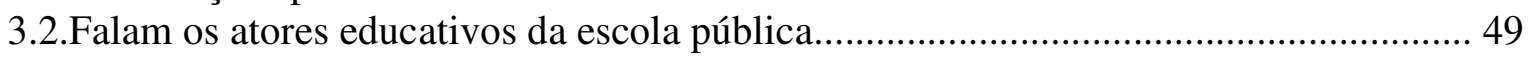

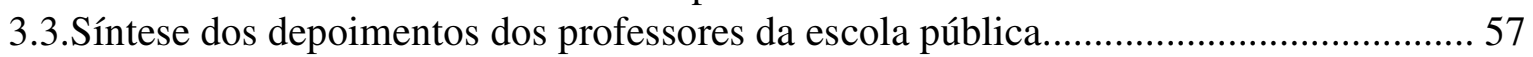

3.4.A educação para a cidadania na visão dos alunos da escola pública............................... 59

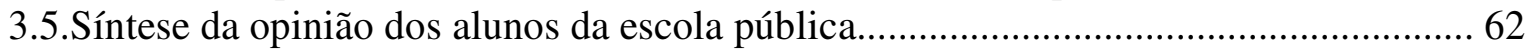

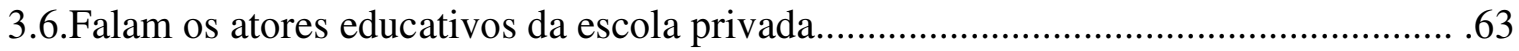

3.7. Síntese dos depoimentos dos professores da escola particular.................................... 75

3.8.A educação para a cidadania na visão dos alunos da escola particular......................... 77

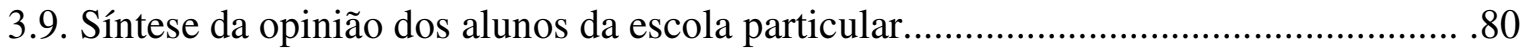

3.10. A cidadania e a pratica da democracia na visão dos membros da comunidade.............81

4. CAPÍTULO - CIDADANIA, DEMOCRACIA, SOCIEDADE PERIFÉRICA, SUBCIDADANIA E EDUCAÇÃ

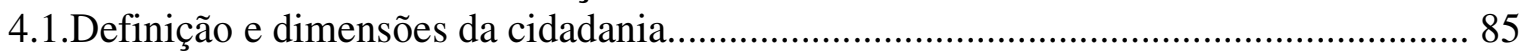

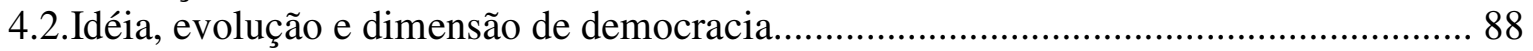

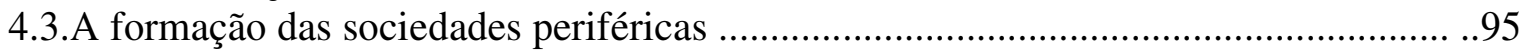

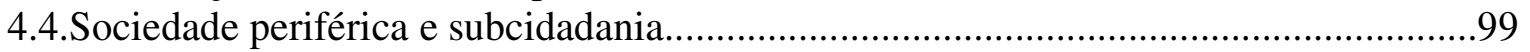

4.5.Status, papéis, dominação, má intenção e manipulação............................................ 104

4.5.Realidade da escola na periferia e a educ. para a cidadania nos documentos oficiais.. 108

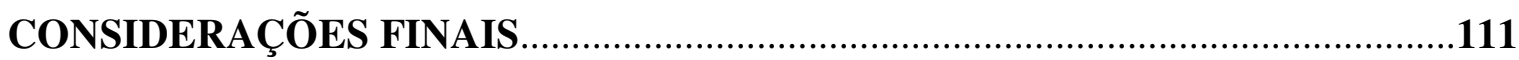

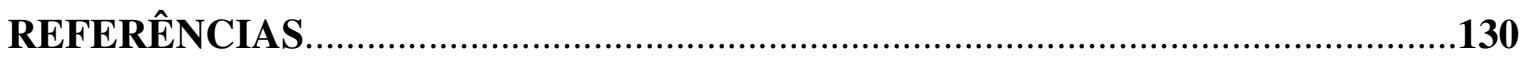

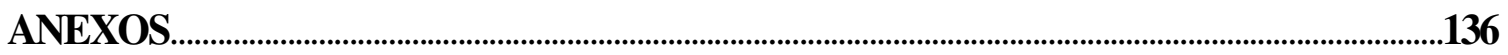




\title{
RESUMO
}

A temática da formação da cidadania, conforme nossa legislação de ensino, mantém-se como um dos eixos básicos da finalidade da educação. Mas se a educação para a cidadania parece ser um imperativo social, o dilema é saber se a educação desenvolvida em instituições de ensino pública e privada da periferia da grande metrópole tem atingido seus objetivos. $\mathrm{O}$ presente trabalho estuda os resultados do processo de educação para o exercício da cidadania e prática da democracia em instituições escolares públicas e privadas dentro do contexto de violência da periferia de São Paulo. Para tanto, foi delimitada e caracterizada a região de Itaquera-Guaianases-Cidade Tiradentes, onde se buscou demonstrar o processo de exclusão social e carências históricas, bem como ausência de ação efetiva de determinados agentes do governo, no exercício de suas funções em prol da comunidade, com o seu descrédito junto à população. Neste quadro foram analisados e comparados o resultado de uma proposta escolar de educação com ênfase na preparação para o exercício da cidadania e a prática da democracia de uma instituição privada de ensino, com os resultados obtidos por uma escola pública, que desenvolve seu programa de educação para a cidadania dentro do contexto geral do Estado. As instituições que serviram de base para a realização do trabalho foram a Escola Estadual Aquilino Ribeiro e o Colégio Professor Augusto Alves Maia. A instituição pública atende o ensino fundamental, com ciclos I ( $1^{\mathrm{a}}$ a $4^{\mathrm{a}}$ séries) e II ( $5^{\mathrm{a}}$ à $8^{\mathrm{a}}$ séries); o ensino médio e além do ensino regular conta também com a modalidade Educação de Jovens e Adultos (EJA). Possui aproximadamente 1.100 alunos freqüentando regularmente seus cursos, que funcionam em três turnos: manhã, tarde e noite. A instituição particular de ensino mantém os cursos de educação infantil, fundamental, médio e técnico, tendo aproximadamente 1200 alunos, funcionando também em três turnos, manhã, tarde e noite. As fontes para a realização do presente trabalho foram as entrevistas com professores, alunos, coordenadores, diretores, pais de alunos e membros das escolas envolvidas. O trabalho abrangeu a ação desenvolvida no período de 1999 a 2006. O objetivo geral do trabalho foi a verificação da compreensão por parte dos alunos e dos membros da comunidade daquilo que foi trabalhado nas escolas sobre os direitos políticos, civis, sociais, econômicos e culturais que procuram assegurar ao indivíduo uma vida digna, com acesso a bens essenciais como moradia, educação, saúde, trabalho, lazer, previdência social, alimentação decente, acesso aos bens culturais e ao conjunto de bens de consumo que são oferecidos às sociedades modernas, identificando as dificuldades dentro de um quadro que sabe ser extremamente adverso.

Palavras chaves: Periferia, educação, cidadania, Estado, direitos, civis, sociais, culturais, violência, desemprego, dificuldades.

\begin{abstract}
The subject of the formation of citizenship, according to our legislation on education, remains one of the basic axes of the purpose of education. However, if education for citizenship seems to be a social imperative, the dilemma is to know if the education in public and private learning institutions in suburbs of the great metropolis has attained its objectives. This work studies the results of the education process for practice of citizenship and democracy in public and private learning institutions in the context of violence of the São Paulo suburbs. To this effect, the region of -Guaianases-Cidade Tiradentes was
\end{abstract}


outlined and characterized, where it was sought to demonstrate the process of social exclusion and historical deficiency, as well as lack of effective action by certain government agents in carrying out their duties on behalf of the community, with their discredit by the population. In this setting, the result of an education proposal was analyzed and compared, with emphasis on preparing one for the practice of citizenship and democracy of a private learning institution, with results obtained by a public school, which developed its education program for citizenship in the general context of the State. The institutions that served as basis to conduct the work were Escola Estadual Aquilino Ribeiro and Colégio Professor Augusto Alves Maia. The public institution includes elementary education, with cycles I ( $2^{\text {nd }}$ to $5^{\text {th }}$ grades $)$ and II $\left(6^{\text {th }}\right.$ to $9^{\text {th }}$ grades $)$; high education and, besides regular education, it also has the modality Youth and Adult Education (EJA). It has approximately 1,100 students regularly attending its courses, which work in three shifts: morning, afternoon and night. The private learning institution maintains kindergarten, elementary school, high school and technical school, with approximately 1,200 students, also working in three shifts - morning, afternoon and night. The sources for this work were interviews with teachers, students, coordinators, directors, parents of students and members of the schools involved. The work covered activities in the period from 1999 to 2006. The overall goal of the work was to verify the understanding by the students and members of the community of what was taught in the schools on political, civil, social, economic and cultural rights that seek to assure the individual of a decent life, with access to essential assets like housing, education, health, work, leisure, social security, decent feeding, access to cultural assets and the set of consumer goods offered to modern society, identifying the difficulties within a setting one knows to be extremely adverse.

Keywords: Suburbs, education, citizenship, State, civil, social, cultural rights, violence, unemployment, difficulties. 


\section{INTRODUÇÃO}

Dado ao quadro de violência no qual a periferia está emoldurada, no contexto em que pode ser identificado como aquele que Jessé Souza (2003) chamou de "um padrão especificamente periférico de cidadania e subcidadania", o presente trabalho procura estudar as condições de prática da cidadania e da democracia, bem como os resultados do processo de educação para o exercício da cidadania e da democracia no espaço periférico, em uma instituição escolar pública e em outra privada de uma grande metrópole ${ }^{2}$, São Paulo. Para tanto foi delimitada e caracterizada uma determinada região da periferia, a região de Itaquera-Guaianases-Cidade Tiradentes, onde se buscou demonstrar o processo de exclusão social e as carências históricas, bem como a ausência de medidas eficazes de governo, em favor da população; o que a leva a sentir-se abandonada e a desacreditar no poder público e em todas suas ações e em seus agentes, desenvolvendo um sentimento de subcidadania. Neste contexto foram analisados o resultado de uma proposta escolar de educação com ênfase na preparação para o exercício da cidadania e conseqüentemente da prática democrática de uma instituição de direito privado; e os resultados obtidos por uma escola pública, que desenvolve seu programa de educação para a cidadania e prática democrática dentro do contexto geral da educação, como forma de contrapor-se à violência. Utilizou-se, para análise, entrevistas com professores, alunos, pais de alunos e equipe escolar envolvida no processo, uma vez que todos são membros da comunidade periférica.

\footnotetext{
${ }^{1}$ SOUZA, Jessé. A CONSTRUÇÃO SOCIAL DA SUBCIDADANIA: Para uma sociologia política da modernidade Periférica. Belo Horizonte UFMG e Rio de Janeiro, IUPERJ, 2003, parte 3-153

${ }^{2}$ Conforme observa Robira (2005. In: ROBIRA, Rosa Tello. Urbanização e Mundialização - estudos sobre a metrópole - São Paulo: Contexto, 2005) uma coisa é a área metropolitana de São Paulo com dezoito milhões de habitantes e um diâmetro urbano compacto de 80 quilômetros e outra coisa é área metropolitana de Barcelona com quatro milhões de habitantes e um diâmetro urbano de 10 quilômetros, dimensões com enormes desproporções, no entanto ambos os contextos territoriais recebem o adjetivo de metropolitanos em seus respectivos países, por isto a referência "grande metrópole".
} 
Foram realizadas vinte e uma entrevistas semi-estruturadas, sendo nove entrevistados na escola pública, a saber, o coordenador Pedagógico do período diurno, três professores e três alunos do ensino médio e dois pais de alunos (membros da comunidade local); na escola particular foram entrevistados a Coordenadora Pedagógica, três professores quatro alunos do ensino médio, três pais de alunos e um profissional liberal (que também fazem parte da comunidade estudada).

\section{Justificativa}

O trabalho justifica-se pela relevância social do tema havendo necessidade de oferecer um retrato da realidade da educação e como ela prepara o aluno para o exercício da cidadania e da democracia dentro do contexto de violência da periferia, onde se identificam dificuldades para educar e para se exercer a cidadania, elemento essencial da democracia e busca-se fornecer subsídios para se formular uma proposta que possa contribuir para a resolução do problema. Para a geografia o trabalho é de grande importância, uma vez que procura retratar como ocorre a organização e as relações sociais dentro do espaço urbano periférico, que acabam gerando um sentimento de inferioridade, de subordinação, de permanente sensação de discriminação que fomenta e desenvolve o sentimento de subcidadania.

Dentro de um processo de educação é necessário que os educandos saibam que os ideais de democracia dentro da conceituação hegemônica, ou da participativa, que devem ser desenvolvidos pelo processo escolar, são essenciais na medida que colocam como ponto central a autodeterminação do povo, enfatizando a visão pedagógica da política. Para Pateman $(1992)^{3}$ a participação é educativa e promove o desenvolvimento da cidadania, a partir de um processo de capacitação e conscientização individual e coletiva - o que, por

\footnotetext{
${ }^{3}$ PATEMAN, Carole. Participação e teoria democrática (Participation and democratie theory). Trad. Luiz Paulo Rouanet. Rio de Janeiro: Paz e Terra, 1992, 161 p.
} 
sua vez, leva a um rompimento de padrões de subordinação e injustiças sociais, o que é extremamente necessário na periferia. É preciso deixar claro aos alunos que a participação, portanto, "promove um ciclo de consciência política e diminuição de desigualdades, conferindo à sociedade, poder legítimo da formação de opinião e de vontade comum" $(\text { HABERMAS, 1995) })^{4}$.

O problema básico sobre o qual levantou-se a hipótese a ser investigada é a dificuldade que existe no exercício da prática da cidadania e da democracia, dado ao conhecido cenário de violência destas áreas urbanas, e, como o processo educacional na periferia trabalha a educação para a cidadania e quais são os resultados efetivos desta ação, porque a sociedade como um todo deposita na educação a esperança de mudanças e parece haver uma ausência de ações efetivas de governo que não investe adequadamente e ou não consegue entender corretamente a periferia, deixando a população exposta à criminalidade e levando-a a desacreditar nas instituições políticas e sociais e a crer na impunidade como regra ${ }^{5}$. Embora muitos autores atribuam este estado de coisas à prática do neoliberalismo, parece ser evidente que antes da alardeada volta à prática dos princípios liberais a partir dos anos de 1970, esta situação evidente de ausência de ações efetivas em função do bem estar da população, por parte dos agentes do Estado, sempre existiram na região periférica e que instituições governamentais, começando pela instituição escolar e pela instituição policial sempre estiveram presentes na região e o que se pode analisar é se elas funcionavam satisfatoriamente, ou não. Certamente hoje ficou mais fácil perceber que existem pontos

\footnotetext{
${ }^{4}$ HABERMAS, Jürgen 'Três Modelos Normativos de Democracia'. Cadernos da Escola do Legislativo, Belo Horizonte, n. 3., p. 107-121, jan./jun., 1995 'Soberania Popular como Procedimento'. Revista Novos Estudos, São Paulo: CEBRAP, n. 26, p. 100-113, março, 1990.

___.. 'Mudança Estrutural da Esfera Pública'. Rio de Janeiro: Tempo Brasileiro: 1984.

5 Em 1996, no Rio de Janeiro, uma pesquisa demonstrou que apenas $8 \%$ dos homicídios resultavam em processo criminal, um ano depois de terem sido cometidos. A maioria acabava arquivada por falta de elementos suficientes. Sem dúvida o caminho mais eficaz para diminuir a criminalidade no Brasil não é o aumento das penas, mas a redução da impunidade. Criminalidade: Sete Teses Equivocadas (Jornal O Globo, SOARES, CANO e LEMGRUBER, 25 de janeiro de 2001). Observe-se que textos jornalísticos, não constituem fontes rigorosas de informação, mas considere-se a importância do trabalho como contribuição na área de direitos humanos.
} 
nos quais o Estado através de seus agentes, que existem e estão presentes na periferia, não cumpre suas funções, o que faz com que haja está transferência da responsabilidade para as organizações não governamentais da sociedade civil, que embora tenham uma atuação positiva, não podem, não devem e não têm como substituir o Estado. Com os últimos acontecimentos de maio de 2006, em que o crime organizado enfrentou abertamente o poder de polícia do Estado, é possível supor que acabou havendo em algum momento um vácuo de poder e que na periferia ele acabou sendo ocupado pelo crime organizado, uma vez que é visível também que as ações criminosas contam com a certeza da impunidade.

Recentemente o Coronel Melo ${ }^{6}$ (quando ainda era o comandante da PM de São Paulo), em entrevista concedida à Revista Isto É, às repórteres Costa e Carelli, ao ser perguntado sobre a fragilização da polícia em virtude da impunidade dos criminosos, respondeu: "a falta de punição prejudica a polícia e a Justiça. Nossa Justiça é extremamente ritualista, protelatória. De tão lenta, ela quase se transforma numa injustiça. A lei atual instrumentaliza o mal”. Ressalve-se que não se recorre à imprensa como uma fonte científica de pesquisa, mas não se pode ignorá-la, uma vez que ela é uma fonte de reprodução de dados do cotidiano.

\section{Objetivo do trabalho}

O objetivo geral do trabalho é a verificação da compreensão por parte do aluno e demais membros da comunidade daquilo que vendo sendo trabalhado acerca dos direitos políticos, civis, sociais, econômicos e culturais que visam a assegurar ao indivíduo uma vida digna, com acesso a bens essenciais como moradia, educação, saúde, trabalho, lazer, previdência social, alimentação decente, acesso aos bens culturais e ao conjunto de bens de

\footnotetext{
${ }^{6}$ A entrevista do Coronel Rui César Melo, comandante da polícia militar de São Paulo, à Isto É, às repórteres Florência Costa e Gabriela Carelli, está disponível na Internet, no site www.terra.com.br/istoe/1601/1601vermelhas. Na prática confirma o que o morador da periferia já sabe de sobejo, que o nosso maior problema é a impunidade, o que toma muito difícil o exercício da cidadania e da própria democracia.
} 
consumo que são oferecidos às sociedades modernas ${ }^{7}$, de forma a demonstrar ou apurar se a intervenção da educação tem sido um fator eficaz de contribuição para o desenvolvimento da cidadania.

Ora, é importante que também o cidadão da periferia possa compreender o que ensinou Bresser-Pereira $^{8}$, que foi de encontro a outros pensadores, de que podemos pensar a história como um processo civilizatório através do qual a humanidade aprende a viver em sociedade, a resolver seus conflitos, e a definir os direitos e obrigações de seus membros.

Ou então como um processo de desenvolvimento econômico através do qual esta mesma humanidade aprende a trabalhar em conjunto, a dividir o trabalho e alocar recursos, a cooperar na produção e competir pelo produto social. No primeiro caso a resolução dos problemas de ação coletiva passa pela institucionalização do Estado e a criação do Direito; no segundo, pela institucionalização dos mercados. Nos dois casos, por um processo de distribuição de poder, de riqueza e de renda entre participantes que satisfaça minimamente os objetivos políticos maiores de ordem, bem-estar, liberdade e a justiça social. Uma sociedade será tanto mais civilizada quanto mais equilibrada, podendo atingir esses objetivos.

A educação não pode e não deve ser o único veículo através do qual os valores da cidadania devem chegar até à população periférica, mas certamente é o mais importante, até porque a instituição escolar é um equipamento social presente em toda periferia e assim sendo deve irradiar estes conceitos e práticas.

\footnotetext{
7“"Depois de cinco décadas dedicadas quase que exclusivamente aos direitos humanos civis e políticos, começamos agora a priorizar a dimensão econômica, social e cultural dos Direitos Humanos”, define Nilmário Miranda membro da Comissão de Direitos Humanos da Câmara dos Deputados. Isto significa que, dentro da evolução dos instrumentos de direito, o mais importante deles, sem dúvida a Declaração Universal dos direitos Humanos, teve como prioridade os direitos civis e políticos, que quase se tomaram sinônimos de Direitos humanos (MIRANDA, N. Relançamento da Declaração Universal: Os Direitos de Segunda Geração Revista Mais Humana -Nº2- Maio 2001, São Paulo, p. 8-11. Por Jacques Sochaczewski - Editor).

${ }^{8}$ (Revista de Filosofia Política - Nova Série, vol.1, 1997: 99-144 (Porto Alegre: Universidade Federal do Rio Grande do Sul, Departamento de Filosofia).
} 
Bresser-Pereira concentra-se no processo civilizatório mais geral, de natureza política, através do qual os homens e mulheres vêm buscando a ordem, a liberdade e a justiça social. Para isto, partindo da proposta básica de Marshall, examina o desenvolvimento da idéia de cidadania a partir da afirmação, primeiro, dos direitos civis, segundo, dos direitos políticos, e terceiro, dos direitos sociais, dando-nos importantes instrumentos de reflexão que devem e precisam ser ensinados na periferia. Na medida, entretanto, em que esses direitos, ainda que não tenham sido efetivamente assegurados, já foram razoavelmente bem definidos e incorporados nas constituições e nas leis dos países civilizados, argumentou o referido autor, que no último quartel do século vinte, um quarto direito de cidadania - os direitos públicos ou, mais precisamente, os direitos republicanos que estão sendo definidos e precisam ser melhor positivados e efetivamente garantidos - e ele definiu estes direitos republicanos "como os direitos que todo cidadão tem que o patrimônio público — seja ele o patrimônio histórico-cultural, seja o patrimônio ambiental, seja o patrimônio econômico ou "res publica" estrito senso — seja efetivamente público, ou seja, de todos e para todos".(Revista de Filosofia Política - Nova Série, vol.1, 1997: 99-144 - Porto Alegre: Universidade Federal do Rio Grande do Sul, Departamento de Filosofia). O público em alguns casos pode ser definido como algo de acesso comum a todos e certamente o cidadão da periferia deve fazer parte deste todos.

Por outro lado o jurista Hélio Bicudo, em 2001, então como presidente da Comissão Interamericana de Direitos Humanos da OEA, destacou em artigo publicado originalmente no Correio Brasiliense que,

Se os chamados direitos civis e políticos asseguram bens da vida (liberdade, igualdade, propriedade) outros direitos, por iguais relevantes (...) encontram-se enunciados no Pacto de San Salvador, adicional à Convenção Americana sobre Direitos Humanos subscrito em 1988 e em vigor a partir de novembro de 1999, o qual impôs aos Estados-partes a obrigação de adotar medidas legislativas ou de outro tipo que sejam necessárias para efetivar os direitos sociais, econômicos e culturais essenciais ao desenvolvimento do ser humano", (apud Revista Mais Humana $b-N^{\circ} 2$ Maio 2001).

Analisando suas colocações parece que o caminho mais óbvio a ser adotado pelos 
Estados, dentro do conjunto de medidas legislativas e ou outras é o da educação, agora é preciso saber se a educação sistematizada, propiciada pela instituição escolar, tem cumprido sua missão de educar para o exercício da cidadania e da prática democrática, satisfazendo a legislação existente.

Considerando o contexto de exclusão social da área estudada ${ }^{9}$ e tendo como foco as investigações sobre as possibilidades, conforme hipótese inicialmente formulada, de averiguar para aquilo que chega a ser quase que uma abstração na periferia - a cidadania e a democracia - bem como ver qual é e qual pode ser o papel da educação, ao final do trabalho, foram reunidos e apresentados dados que possam propor subsídios para os envolvidos no processo educativo da periferia no sentido de contribuir, na medida em que se conhecer a realidade do espaço periférico, a partir do ponto de vista do sujeito da própria história, uma vez que recorrendo ao princípio da história oral (Thompson, 2002), deu-se voz a quem não tem voz, o que pode tornar possível a elaboração de um ou diversos projetos de intervenção que possam tornar possível a educação voltada para o exercício da cidadania e prática da democracia e evidentemente o combate ao sentimento de discriminação e subcidadania de que a periferia parece ser vítima.

\section{Metodologia}

Segundo Minayo (1998), todo processo de conhecimento na investigação social acaba permeado pelas diferentes visões de mundo, tanto dos atores sociais como do pesquisador que, por sua vez, também acaba nessa interação social, sendo parte da observação.

Acrescente-se que a base teórico-metodológica que deu suporte à pesquisa contou também com o recurso da História Oral, como um apoio necessário para alcançar os objetivos propostos nesta coleta, investigação e analise de material.

\footnotetext{
${ }^{9}$ Em conformidade com conceito de exclusão social de Castells (2000) "como uma expressão que inclui todas as modalidades de miséria, que vai do desempregado recorrente ou de longa duração, passando pelo jovem da periferia ao sem domicílio fixo".
} 
O principal instrumento para a coleta de dados foi a entrevista semi-estruturada, lembrando que cada uma delas foi transcrita literalmente e foi preservado o tom oral, de modo a garantir a fidedignidade do uso das informações. A linguagem utilizada no questionário foi simples e direta para que o respondente compreendesse com clareza o que estava sendo perguntado, sem perder a perspectiva de que "a evidência oral, transformando os "objetos" de estudo em "sujeitos", contribui para uma história que não só é mais rica, mais viva e mais comovente, mas também mais verdadeira” (THOMPSON, 2002, p.137) ou ainda "que as entrevistas, como todo testemunho, contêm informações que podem ser avaliadas (...) e podem fornecer-nos informações tão válidas quanto as que podemos obter de qualquer outra fonte humana" (THOMPSON, 2002, p.315). A coleta de dados de forma sistematizada foi realizada de 2005 a 2007.

Os textos resultantes encontram-se em anexo, ficando à disposição na biblioteca da Universidade de São Paulo para a consulta de outros pesquisadores.

Portanto dentro desta abordagem quer se deixar claro que não se buscou a verdade única, explicações causais ou generalizações e os fenômenos são únicos do mesmo modo como são apreendidos e interpretados.

\section{Educação, democracia e cidadania questão de Ideologia ou de representação?}

Considerando que nos documentos e discursos oficiais, o poder público parece querer efetivar uma educação que leve à prática da democracia e cidadania, cabe a pergunta: então por que tal vontade não se concretiza?

Em busca de uma resposta é preciso analisar alguns fatos tais como a Ideologia, que é um termo que nasceu no século XVIII, no transcurso da Revolução Francesa, proposta por Destut de Tracy, um dos líderes dos enciclopedistas franceses e foi generalizado por 
Napoleão, que para acusar de fictícias e falsas, as idéias defendidas pelos enciclopedistas, chamou-os, pejorativamente, de ideólogos. Desde então ela passou a significar um conjunto aparentemente racional de idéias que procura ocultar a sua origem nos interesses sociais de um grupo particular da sociedade. Para Marx, passou a ter uma conotação de ilusão, falsa consciência, "um sistema de crenças ilusórias relacionadas a uma classe social determinada" e posteriormente a Marx, mas dentro do próprio marxismo, sobretudo na obra de Lênin, passou a significar "qualquer concepção da realidade social ou política, vinculada aos interesses de certas classes sociais particulares". (LOWY, 1985, p. 12).

E por sua vez, representação, etimologicamente, provém da forma latina "repraesentare" - fazer presente ou apresentar de novo. Fazer presente alguém ou alguma coisa ausente, inclusive uma idéia, por intermédio da presença de um objeto. Ou ainda pode-se entender que "a representação, por sua vez, é o processo pela qual a mente torna presente diante de si a imagem, a idéia ou o conceito de algum objeto" (COTRIM, 2000, P.58). O conhecimento desta forma exige sempre a relação entre dois elementos, ou seja, um sujeito conhecedor e um objeto conhecido, então o sujeito conhecedor apreende o objeto e o representa mentalmente. Como o Estado apreende a periferia e como a representa?

A pergunta é: a cidadania é uma questão ideológica para os que exercem o poder? As elites dominantes são tão poderosas que se impõem ao Estado impedindo que o poder público atenda a periferia propiciando-lhe condições adequadas de vida? Ou realmente os que exercem o poder de governo concebem a cidadania de uma maneira diferente para o pobre, porque o representa como alguém incapaz de entender as dimensões de seus direitos? Qual a representação que as elites dominantes faz do cidadão pobre da periferia? O pobre ainda se constitui em uma ameaça ao domínio das elites e por isto precisa ser mantido em condições subalternas e sob as tenazes do poder repressivo? Difícil apresentar 
alguma conclusão, porque existe um discurso oficial que prega reformas e uma realidade objetiva que desmente o discurso. Talvez haja a intenção de realmente mudar, mas não se consiga fazer a representação adequada do que realmente o cidadão da periferia precisa, então se evidencia aquele déficit de articulação entre práticas e idéias.

\section{Estrutura do trabalho}

O trabalho foi elaborado contendo além da Introdução, na qual identifica-se a região estudada, a justificativa, o objetivo, a metodologia e a estrutura do trabalho, onde se busca caracterizar a periferia e seus problemas típicos; mais quatro capítulos e uma parte de Considerações Finais.

No capítulo um - Periferia, violência, exclusão e desemprego - procurou caracterizarse a região estudada e seu quadro de violência, desemprego, carências e exclusões, históricas.

No capítulo dois - Caracterização das Escolas - buscou-se caracterizar as escolas que serviram de fontes para a realização deste trabalho e suas diretrizes de educação para a cidadania e democracia.

No terceiro capítulo - Os Atores Falam de Sua Experiência - identificou-se quem são os atores que protagonizaram o presente trabalho, com a devida fala de cada um, acerca de experiência de educação para a cidadania e democracia. Novamente recorrendo ao apoio da história oral, que segundo Thompson (2002) "devolve a história às pessoas em suas próprias palavras", uma vez que responde a questão que ele mesmo formula "de quem é a voz - ou de quem são as vozes - que se deve ouvir?”. Portanto, buscou-se dar voz a quem não a possuí.

No capítulo quarto - Cidadania, democracia, sociedades periféricas, subcidadania e educação - procurou-se explicar os conceitos e dimensões de Cidadania e democracia, a 
formação das sociedades periféricas, o desenvolvimento das desigualdades e a origem do conceito de subcidadania e o tratamento dado para o tema proposto nos documentos oficiais e como ela tem sido vista hoje na periferia .

Nas considerações finais apresentou-se a síntese do trabalho e elementos que possam contribuir com a educação para a cidadania e prática da democracia. 


\section{PERIFERIA, VIOLÊNCIA, EXCLUSÃO E DESEMPREGO.}

\subsection{Exercício de compreensão da periferia}

Para melhor compreender a idéia e a dificuldade de se exercer a cidadania e a democracia na periferia, será preciso entender também a dificuldade de se educar, por que esses valores passam necessariamente pela educação.

Para formularmos uma imagem do que seja a periferia e suas dificuldades vamos recorrer à lembrança da política agrária implementada logo após o golpe militar de 1964 e suas consequiências, quando o então regime autoritário recém instalado promoveu um verdadeiro êxodo rural, uma vez que para realizar sua política agrária optou por aquilo que se chamou de modernização conservadora dentro do conceito da chamada Revolução Verde $^{10}$. "Apoiadas num discurso de valorização e de ampla confiança do conhecimento científico formal, as propostas da Revolução Verde apresentavam-se como receitas impositivas. (ROSA, 1998, p.19)".

$\mathrm{Na}$ prática acontecia que as fundações norte americanas Ford, Rockefeller Kellog e a Agência Internacional para o desenvolvimento, bem como a FAO (Organização para a Alimentação de Agricultura da ONU), valendo-se da articulação entre as indústrias química e mecânica que propiciaram um rápido avanço tecnológico no setor agrícola na década de sessenta, realizaram a formulação de propostas voltadas aos países subdesenvolvidos. A essência era a agricultura voltada para a exportação e um intenso direcionamento de subsídios e créditos aos grandes proprietários, promovendo um processo de mecanização da agricultura. Observa Valim (1998, p. 15) "Essa mudança no modo de produzir, por sua vez trouxe várias conseqüências, como o aumento da produção e da produtividade, a concentração

\footnotetext{
${ }^{10}$ ROSA, Antonio Vitor. Agricultura e Meio Ambiente, Atual, São Paulo: 1998.
} 
das terras, a dissolução das antigas formas de trabalho".

Para ela, tal modelo levou a uma maior concentração da propriedade e do uso da terra, pois um grande número de pequenos agricultores, proprietários, posseiros, foreiros, parceiros, meeiros e arrendatários, foram expulsos do campo. A perda da terra levou a uma grande exclusão social, pois esta população acabou fixando-se na periferia das grandes cidades, em um quadro de carências absolutas. Valim (1998) explica que "o intenso fluxo migratório para as cidades provocou não apenas o crescimento das grandes metrópoles [...] mas também o inchamento dos municípios periféricos, ou das cidades dormitórios [...] a esse fenômeno dá-se o nome de "periferização". (VALIM, 1998, p. 16). Embora aqui seja preciso reconhecer que os problemas já existiam nas regiões, que funcionavam como dormitórios no entorno dos grandes centros e eram então sub-urbanizadas, houve uma aceleração e agravamento do processo.

Estes fatos propiciaram um inchaço das cidades, gerando graves problemas relativos ao transporte, moradia, abastecimento, energia elétrica, saneamento básico e um crescimento contínuo da pobreza, com a deterioração progressiva das condições de vida urbanas e foi neste contexto que houve a organização dos movimentos reivindicatórios das periferias a partir da década de 1970 que levaram a uma intensa mobilização das comunidades periféricas.

Temos também a idéia de Robira ${ }^{11}$ (2005), que vai de encontro ao que muitos autores pensam, que para explicar o conceito generalizante ou dominante de espaço metropolitano, bem como para explorar teoricamente alguns processos de expansão da organização urbana de território, lança mão da idéia de Harvey/Luxemburgo (HARVEY, 2004, p.112) da necessidade de "território não-capitalistas" ou "territórios adormecidos", que ela vai denominar "territórios-reserva". Essa autora qualifica o território metropolitano como

\footnotetext{
${ }^{11}$ CARLOS, Ana Fani Alessandri (Org.). CARRERAS, Caries (Org.). A geografia e a produção do espaço da metrópole: entre o público e o privado. In: ROBIRA, Rosa Tello. Urbanização e Mundialização - estudos sobre a metrópole - São Paulo: Contexto, 2005, p.09-19.
} 
aquele mais ou menos urbanizado que fica em torno de uma grande cidade e depende dela. Para tanto cita a "teoria mecânico-funcionalista de Le Corbusier (apud, ROBIRA, p.12) de que nas áreas metropolitanas não existem funções senão as de residir, trabalhar, descansar e circular". Segundo ela esta definição simplista do território metropolitano permite aos poderes públicos valorizar muito positivamente suas próprias políticas de investimento em infra-estruturas e espaços públicos frente aos cidadãos, porque as cifras procuram engalanar discursos políticos que mascaram práticas públicas mais orientadas a reforçar centralidades urbanas. Para ela os "territórios-reserva" - estão fora do sistema regular de produção e consumo. Seus habitantes constituem reserva de mão-de-obra metropolitana, portanto o subemprego e o desemprego são situações dominantes. E a necessidade de sobrevivência leva ao desenvolvimento de economias internas e irregulares, baseadas especialmente no comércio ilegal, tanto de bens legais como ilegais (drogas, armas, pirataria e falsificação de eletrônicos, mídias, etc). A manutenção de parte da população em condições de precariedade, criminalizada socialmente e guetizada urbanisticamente, permite a manutenção de cidadãos "normalizados" com medo e insegurança; sentimentos que acabam por se constituir em recursos econômicos e políticos para a produção e a gestão da segurança. Desta forma a miséria é um recurso de alimentação dos circuitos dos capitais nacionais e internacionais, relacionados com a produção da segurança, movimentando a indústria da construção, da eletrônica, do armamento, dos seguros, do setor de serviços, etc. Além disso, a insegurança alimenta também o discurso político: as promessas para melhorar as condições de vida. É o que ela chamou de a gestão pública do medo.

Na realidade tais colocações apenas constatam a existência de determinados quadros da realidade periférica, tais como a situação de desemprego e subemprego; assim como o desenvolvimento do comércio de bens legais e ilegais que acaba sendo uma estratégia de 
sobrevivência, mas certamente não correspondem objetivamente à realidade, não parece em momento algum que haja interesse dos poderes públicos em manter a insegurança para alimentar discursos políticos, bem como manter o quadro de carências, embora, a situação sempre seja explorada por políticos inescrupulosos, tal pensamento parece ir além da realidade.

Por sua vez Carlos (2005), ao discorrer sobre a centralidade da metrópole, coloca a idéia de desintegração e deterioração de outros espaços o que caracteriza a situação da periferia. E ao falar no processo de realização de reprodução do capital, cita a dominação de lugares pelo narcotráfico, como condição da realização do comércio de droga, em uma clara indicação de que a metrópole já incorporou e ou reconhece o comércio ilícito de droga, como um fator de acumulação e reprodução do capital fazendo parte da vida cotidiana dos cidadãos. Não há como negar a existência de lugares dominados pelo narcotráfico, mas sem dúvida o tráfico existe em qualquer tipo de sociedade, não pode ser caracterizado como uma atividade típica das sociedades capitalistas e nem o tráfico como algo exclusivo da periferia.

Damiani (2005) discute as relações entre a Geografia e a produção do espaço da metrópole a partir da questão do público e do privado e coloca a idéia de que de alguma forma a "periferia é provisória", ao considerar a reprodução histórica dessa formação social típica. Ela cita a presença de uma mobilização popular nas duas últimas décadas, mas segundo ela, realizados conforme institucionalidades postas, com uma nova abordagem do que ela chamou de "clientelismo institucional", uma vez que as representações políticas de “movimentos sociais de base”, são instrumentalizadas segundo os desígnios das estruturas do Estado. Refere-se à urbanização como negócio e faz referência à metrópole (São Paulo), envolta em um anel formado por milhões de habitantes, com um ordenamento típico que implica em casas construídas de toda espécie, tais como: grandes conjuntos habitacionais; 
comercialização coletiva e popular de lotes, comercialização clandestina de loteamentos, mutirões e outros. Ela conclui que isto forma manchas empobrecidas nos limites urbanos e que essa pobreza não vem estritamente da exploração do trabalho, mas da exclusão na produção, de uma massa que ela chamou de desempregados permanentes, passando também pelo desemprego temporário, o que acaba retirando a identidade das pessoas, gerando miséria e violência.

Ainda no sentido de uma melhor compreensão podemos recorrer aos dados da Comissão Municipal de Direitos Humanos, que divulgou recentemente os resultados de uma pesquisa inédita sobre as condições de vida em diferentes bairros da capital paulista. ${ }^{12}$

Na faixa de baixa garantia de cumprimento dos direitos humanos ficaram Tremembé, Campo
Limpo, Casa Verde, Freguesia do Ó, Jabaquara, Itaquera e Parelheiros. Ao passo que Itaim
Paulista, São Miguel Paulista, São Mateus, Capela do Socorro, M'boi Mirim, Cidade Ademar
e Guaianases terminaram como áreas de precária garantia de direitos humanos. (Plantão
Globo 01/ 2006-13h08m - página da Internet 9 de janeiro de 2006. Versão on line).

Isto evidencia a violência na periferia e demonstra que o Estado não consegue garantir os direitos humanos nas áreas periféricas, e eles são essenciais não só ao exercício da cidadania e à prática democrática, mas sim à própria sobrevivência física do indivíduo, desta forma parece realmente haver uma região onde os direitos e conseqüentemente a vida não precisam ser preservados em sua plenitude, o que indica a existência de uma subcidadania institucionalizada.

Segundo Paulo César Pinheiro ${ }^{13}$, em artigo disponível em site da Comissão Teotônio Vilela (artigo original de 22/09/1996 - As relações criminosas) essa violência na periferia é endêmica - num contexto de desigualdades econômicas e sociais brutais - "longe está de ser um fenômeno novo, aqui e na América Latina. A situação agravou-se nas duas últimas décadas em parte em conseqüência das políticas econômicas que aprofundaram a concentração da renda e condenaram milhões à pobreza e à exclusão social". Continua o

\footnotetext{
${ }^{12}$ PLANTÃo GLOBO 07/01/2006 - 13h08m - página da Internet 9 de janeiro de 2006, versão on line.

${ }^{13} \mathrm{As}$ relações criminosas - artigo disponível no site da fundação Teotônio Vilela. http://ctv.incubadora.fapesp.br/portal/V.artigos/relacoescriminosas em artigo original de 22/09/1996 -1
} 
raciocínio e conclui que "é também o resultado direto de longa tradição de práticas autoritárias das elites contra as "não-elites" - práticas rotineiramente reproduzidas nas relações sociais entre os próprios excluídos". Constata em seguida que "o retorno ao constitucionalismo democrático pouco fez para erradicar as práticas autoritárias presentes no Estado e na sociedade".

\subsection{0 cenário atualizado da periferia da maior metrópole do Brasil.}

A área ou região que serve ao presente estudo, situada dentro do eixo ItaqueraGuaianases, ainda é predominantemente um grande dormitório e distribui-se em uma base física de $87 \mathrm{~km} 2$, com uma população com mais de um milhão de habitantes ${ }^{14}$, cuja maioria é obrigada a fazer a migração pendular diária. Na periferia a rotina é de levantar-se de madrugada, passar entre uma hora ou mais horas dentro de um coletivo (ônibus, trem ou metrô) lotado, para se chegar ao trabalho e levar mais algumas horas para retornar para casa à noite, uma vez que os serviços de transportes coletivos são precários, para começar tudo de novo no outro dia. As poucas vias que fazem a ligação entre a periferia e as centralidades urbanas e a outras regiões da cidade, estão sempre congestionadas, o que faz com que o trânsito seja caótico e estressante.

O metrô foi implantado em Itaquera nos meados da década de oitenta do século passado, e não chegou a Guaianases, conforme foi anunciado pelo então governador (19871990) Orestes Quércia e cujas obras por ele foram iniciadas, mas no final da década de noventa do século passado, no governo Mario Covas, virou Trem Espanhol.

\footnotetext{
${ }^{14}$ A região é composta por Itaquera - Guaianases - Cidade Tiradentes. Itaquera se divide em quatro distritos: Itaquera, Parque do Carmo, Cidade Líder e José Bonifácio, com um total de 111.773 residências particulares e 12.198 moradores em favelas, com uma estimativa populacional no ano de 2000 de 451.421 (estima-se para 2010 uma população de 529.600) dos quais 112.821 concluíram o ensino fundamental, 64.010 o ensino médio e 10.005 o superior completo. Não tiveram a escolaridade determinada 7.188 pessoas, com escolaridade inferior a um ano contou-se 27.344 pessoas e declararam ter o ensino fundamental incompleto 189.065 moradores. Guaianases se divide em dois distritos: Lajeado e Guaianases. A cidade Tiradentes, área também estudada, hoje é um distrito independente. A estimativa é que os três distritos de Guaianases em 2010 terão 712.246 habitantes, sendo que as subprefeituras não forneceram dados sobre residências, favelas e escolaridade da população. Os dados colhidos nas subprefeituras são do IBGE, censo de 2000.
} 
Existe um hospital público em Itaquera e outro em Guaianases; uma universidade privada em Itaquera e um Instituto Isolado de Educação Superior em Guaianases, o que parece muito pouco para um universo populacional tão grande.

A rede de esgotos chegou na região no final da década de oitenta e as ruas e calçadas que um dia foram públicas, pois ao que consta eram de acesso comum a todos, hoje são privatizadas por flanelinhas e ambulantes (os demais membros da comunidade andam pelo meio da rua disputando espaço com os veículos automotores), que podem ter sido empurrados para a economia informal pelo desemprego e talvez tenham ficado por opção.

O cenário da periferia de São Paulo, na área estudada, é de carências, alguns quadros da realidade, permanecem em nossos dias, semelhantes ao que eram na década de setenta do século passado, segundo informações prestadas por membros da comunidade. Ainda hoje, é comum deparar-se com quiosques ou barracas que vendem bebidas, salgados, alimentos, roupas, mídias eletrônicas, todo e qualquer tipo de produto, inclusive drogas, em meio à sujeira e poluição do espaço público aberto; são verdadeiras lanchonetes, restaurantes, mercearias, bares, magazines, centro de criminalidade, etc. Certamente que em uma sociedade organizada tais estabelecimentos não funcionariam por absoluta falta de condições sanitárias e seriam tratados de acordo com o Código Penal, começando pelo atentado à saúde de outrem, passando pelo descaminho (venda de produtos contrabandeados), falsificação de produtos e terminando com o tráfico de drogas.

Ainda é comum a venda de gêneros alimentícios sem o menor cuidado sanitário, em que animais como caprinos, suínos e mesmo bovinos, são mortos e desossados em quintais e vendidos sobre pranchas de madeira em barracas permanentes ao lado de peixes, pastéis, etc. Não existe fiscalização, não adianta denunciar o que é visível para todos, o Estado como elemento de intervenção e com capacidade inclusive, para promover uma fiscalização e mesmo educação sanitária, é uma entidade ausente, no que tange a ações 
efetivas, embora tenha agentes designados para realizar esta função na região, mas com os quais a comunidade não se importa, pois confia no poder da propina. E esta situação não começou agora, pela fala das pessoas, ele nunca esteve presente ativamente nas três ou quatro últimas décadas, que é o período sobre o qual foi possível o trabalho abranger através da coleta de dados, conforme a experiência de vida das pessoas, tendo como base a história oral.

Os agentes do Estado aparecem quando se trata de assegurar o patrimônio dos pequenos poderosos locais, que são os empresários e que podem contratar e pagar diretamente os serviços, tais como o de segurança e outros que deveriam ser públicos, pelos quais a sociedade como um todo paga.

A pena de morte é algo que sempre existiu na periferia, onde a polícia parece ser uma instituição privatizada, podendo caçar e matar bandidos pobres, mas sempre prestando serviços particulares e ou conforme interesses próprios; não se importa ou não tem como se importar com ações como furtos, roubos, agressões, perturbação do sossego público, infrações do trânsito (como direção perigosa), que se constituem em ameaças à vida alheia e outros delitos que se cometem contra o cidadão comum, que é o trabalhador pobre.

Nos primeiros meses de ocupação do Iraque (realizada por forças ocidentais capitaneadas pelos EUA), em 2004, diversos órgãos da imprensa falada e escrita, gostavam de comparar o número de mortos por dia na cidade de São Paulo e na do Rio de Janeiro com o número de mortes que ocorriam em todo o Iraque ocupado e demonstravam os números nos primeiros dias que o número de mortos em cada uma de nossas cidades era maior, o que permitia falar-se em estado de guerra civil, o que se tornou muito claro a partir de 12 de maio de 2006, quando o crime organizado resolveu declarar guerra e atacar as instituições policiais em São Paulo.

Como forma de evidenciar o quadro de violência, pesquisa Data Folha, veiculada na 
Internet, em 16 de maio de 2004, apontava que 52\% da população de toda a cidade de São Paulo têm medo da polícia militar (os números provavelmente seriam diferentes se a mesma pesquisa fosse feita apenas na periferia, pois esta população é a grande vítima da polícia), isto talvez explique o ódio que o crime organizado, cujos membros, tudo indica, são oriundos da periferia, parece nutrir pela instituição policial.

O morador da periferia acredita na existência de um profundo preconceito (que é percebido ao longo do trabalho), contra a periferia. A população em sua maioria é composta de migrantes nordestinos e seus descendentes (o que se nota facilmente pelo biótipo, pelo sotaque, camelôs e inúmeras lojas que vendem produtos regionais), havendo por parte da minoria que não tem esta origem a recorrência à expressão pejorativa "baianada" para designá-la, atribuindo a ela a violência e a criminalidade que se disseminou na região, nas últimas décadas. Em relação a este tipo de atitude observou Magnoli (1997, p.124) "a atitude preconceituosa enxergou nos fluxos de nordestinos o espectro de invasão da pobreza, em vez de enxergar o papel desempenhado pela mão-deobra migrante". Vale aqui lembrar, que por razões histórico-sociológicas, a pobreza continua identificada com marginalidade e violência. Essa inclusive parece ser a fonte do preconceito contra os moradores da Zona Leste de São Paulo.

O cenário de carências da periferia, está interligado com as questões mundiais e com o destino econômico, político e social do Brasil, porque é resultado da formulação de políticas públicas de âmbito macroeconômico.

\subsection{Violência, exclusão e desemprego.}

Observou Tiriba $(2001)^{15}$, que "basta andar pelas ruas dos grandes centros urbanos para constatar o quanto o fim da "sociedade do emprego", vem desestruturando a vida de tantas

15 TIRIBA, Lia. Economia Popular e Cultura do Trabalho: Pedagogias de produção associada. Ijuí - RS, UNIJUI. 2001. 
pessoas", mas nos países desenvolvidos as taxas de desemprego hoje estão próximas de zero, o que limita a afirmação da autora às sociedades periféricas. Sustenta tal argumentação apontando dados da Organização Internacional do Trabalho (OIT), que indica que, em 1996, já existia um bilhão de desempregados e subempregados no planeta, algo que corresponde a quase $30 \%$ da força de trabalho. Em seguida demonstrou que no inicio do terceiro milênio o desemprego apresentava novas dimensões, identificando primeiro a perplexidade dos jovens diante da dificuldade de encontrar um primeiro emprego e inserir-se no mundo do trabalho; segundo, além das dificuldades iniciais do primeiro emprego, que também não são jogados no "olho da rua" apenas os trabalhadores com baixo nível de escolaridade, e, portanto, considerados semi ou "desqualificados", mas também parte significativa daqueles que adquiriram as mais variadas gamas de qualificação, o que parece ser discutível, uma vez que não apresenta dados para tal afirmativa. Considera que o desemprego aflige tanto as camadas mais empobrecidas como as camadas médias da sociedade, produzindo uma simbiose e, ao mesmo tempo enfrentamento, entre os tradicionais e os novos excluídos. Para ela as pessoas oriundas desses segmentos sociais encontram-se em um mesmo campo de luta; todavia, o desespero em busca de ocupar uma posição no mercado, faz com que, muitas vezes, elas passem a lutar em trincheiras diferentes. E finalmente aponta a terceira dimensão que é a duração prolongada do desemprego, levando, muito comumente, as pessoas ao trabalho por conta própria, ou seja, a buscar - individual ou coletivamente - alternativas para a satisfação dos seus meios de sobrevivência. Este último fato por ela descrito é facilmente percebido na periferia da área metropolitana estudada.

Outro dado polêmico é o que ela coloca como sendo que as políticas de globalização e internacionalização da economia, em detrimento de um desenvolvimento autônomo e autocentrado nas necessidades da população, têm contribuído para produzir meninos de rua 
no Brasil, “canalitas no Paraguai, polilas na Bolívia, gamines da Colômbia - todos eles pequenos trabalhadores, meninos famintos que povoam os países periféricos" (TIRIBA, 2001, p.25). Polêmico porque os meninos realmente existem, porém estes países são pouco globalizados e a situação parece existir muito antes da ênfase que se dá à globalização, o que demonstra que ela não pode ser responsabilizada por esta situação. A mesma autora afirma também que a violência nos grandes centros urbanos, tanto por parte da polícia, como dos chamados "bandidos", talvez seja a expressão maior da "sociedade dos três terços”, uma vez que para ela a sociedade está dividida em três terços: um terço composto pelas camadas sociais em ascensão e com grande poder de consumo; um terço precariamente incluído e satisfazendo suas necessidades básicas de forma parcial; e um terço de excluídos (desempregados, subempregados e aqueles que tentam sobreviver do trabalho por conta própria).

As pessoas inventam estratégias econômicas para defender-se das injustiças sociais. Como fato novo surge o fenômeno generalizado, sobretudo nos países em "via de desenvolvimento", como parte integrante da nova ordem internacional em que o trabalho assalariado vem perdendo sua centralidade nas relações entre capital e trabalho. Para uma imensa quantidade da população, o que resta é o sonho,

de montar uma barraquinha de cachorro-quente, numa esquina, de preferência longe da violência, da fiscalização, do controle do Estado, e, quem sabe - burlando ou não a lei dos mais fortes [...] uma minifábrica de pizza ou até mesmo uma fabriqueta de calcinhas, que possa um dia, concorrer ou ser terceirizada por uma De Millus",...(TIRIBA, 2001, p. 25).

Kabunda (1994) ${ }^{16}$, ao falar que as fontes de renda distintas daquelas que existem no setor formal assalariado são as mais variadas observou que o mais freqüente "é que o operário, sem recursos, procure desesperadamente sobreviver mediante o roubo de instrumentos de produção e de peças de reposição na empresa onde trabalha, para instalar-

16 KABUNDA, Badi M. Las estratégias de supervivência em África y el Tercer Mundo. In: Missiones Extranjeras. Madrid: EME, mayo-agosto de 1996. p. 210-234.

"Programas de ajuste estructural y alernativas populares em África. In: Alfoz, Madrid, no 108, 1994, p. 125-132 
se como pequeno produtor independente" (KABUNDA, 1994, p. 130).

No caso da periferia delimitada para o presente estudo, o engajamento de jovens no tráfico de drogas, como estratégia de sobrevivência, parece ser muito evidente, mas a questão transcende o tráfico, porque existe ainda a busca de forma de inclusão no processo de consumo, em evidente conflito com a lei, através do furto, do roubo e do latrocínio, etc., que gera um quadro de violência e insegurança permanente na periferia. 


\section{CARACTERIZAÇÃO DAS ESCOLAS}

\subsection{Fontes}

As fontes para a realização do presente estudo são entrevistas com professores, alunos, coordenadores e diretores das escolas envolvidas. Aqui se ressalta a lembrança de Thompson "nas transmissões de caráter histórico, o que torna os programas vivos é a introdução das pessoas, os atores originais". (THOMPSON, Paul. A voz do passado Historia Oral, 2002, p.35). A escolha das instituições ocorreu em função da região em que se situam e da natureza do trabalho que realizam, que em ambas envolve projetos de educação para a cidadania.

As instituições estudadas ficam a uma distância de aproximadamente $5 \mathrm{Km}$, entre si, a escola particular, denominada Colégio Professor Augusto Alves Maia situa-se na região limítrofe entre Itaquera e Guaianases, nas imediações do Conjunto Habitacional José Bonifácio que começa em Itaquera e termina em Guaianases e a escola pública chamada de Escola Estadual Aquilino Ribeiro, fica em Guaianases no Conjunto Habitacional Prestes Maia.

O ambiente das imediações das duas instituições, dentro do espaço geográfico que as separa é praticamente o mesmo, apresenta o mesmo perfil no que tange à violência e tráfico de drogas. Na citada região periférica, quanto maior a distância do centro em direção ao extremo leste da cidade, maior é o processo de desvalorização imobiliária. Entre os dois conjuntos, mesmo que os imóveis tenham um padrão de construção idênticos os que se situam em Itaquera são de maior valor e aparentam ter um melhor estado de conservação, e com maior infra-estrutura e equipamentos sociais, como área de lazer e bibliotecas, entre 
outros, que são fatores indicativos de que o bairro tem maior poder aquisitivo ou é menos pobre do que Guaianases ${ }^{17}$.

Dentro do distrito existem enormes diferenças, Itaquera não apresenta uma homogeneidade. Como em todo espaço urbano, existem áreas mais nobres e áreas menos nobres, existindo segmentos em Itaquera com uma renda muito superior à da área situada no espaço geográfico que separa as duas escolas; conseqüentemente com uma renda superior à dos conjuntos habitacionais.

A escola particular atrai uma clientela de áreas mais privilegiadas da região, como por exemplo, do Parque do Carmo e Vila Carmosina (distritos ou bairros de Itaquera), conforme documentos de matrícula analisados (o sistema é inteiramente, informatizado, o que facilita a coleta de dados) o que faz com que sua clientela apresente um melhor poder aquisitivo. Por exemplo, conforme informação prestada pela direção (que prestou total colaboração), a instituição realizou pesquisa junto aos seus alunos (em 2002) para implantar sistema de educação com material didático personalizado com suporte de atendimento e apoio na Internet e quase que $100 \%$ (93\%) disseram ter computador em casa. A escola pública, conforme seu coordenador, ainda não realizou este tipo de pesquisa, mas já procurou apurar este dado, junto aos seus alunos, através de conversa informal, por parte de professores, coordenadores e diretores, tendo chegado à conclusão de que os alunos que possuem computador constituem exceções.

\subsection{A escola pública - caracterização geral}

A escola pública que colaborou para a elaboração do presente trabalho, de forma geral

\footnotetext{
${ }^{17}$ A renda, da grande maioria, da população dos dois bairros, segundo o Núcleo de Pesquisa em Qualidade de Vida (NPQV), tendo como fonte dados do CENSO IBGE de 2000, (FCECA, P.8I), em 2000 a renda era de $\mathrm{R} \$ 566,475$ (aproximadamente 4 salários mínimos da época) em Itaquera e de $\mathrm{R} \$ 430,957$ (aproximadamente 3 salários mínimos da época) em Guaianases, sendo a diferença de R \$ 135,518, no momento em que o salário mínimo no Brasil era de $\mathrm{R} \$ 151,00$. A diferença de renda entre os dois distritos, portanto, era de quase um salário mínimo (chegava a 90\%) e do ponto de vista absoluto, não tem uma grande diferença, mas do ponto de vista relativo, na região, este diferencial é altamente significativo.
} 
é uma instituição que possui uma boa aparência, está instalada em um prédio que não apresenta sinais de depredação e nem o conjunto de grades de segurança, que são típicas em instituições escolares da periferia.

Atende o ensino fundamental, com ciclos I (1a à 4a séries) e II (5a à 8 a séries); o ensino médio e além do ensino regular atende também a modalidade Educação de Jovens e Adultos (EJA). Conta com aproximadamente 1.100 alunos freqüentando regularmente seus cursos, que funcionam em três turnos: manhã, tarde e noite.

Apresenta instalações amplas e aparentemente bem cuidadas, tem 14 salas de aulas e dependências administrativas que acomodam diretoria, vice-diretoria, secretaria, coordenadoria, sala de professores, biblioteca com sala de leitura e aproximadamente 3.500 volumes, incluindo os de conteúdo didáticos e laboratório, que eles também denominam de sala de informática, com 10 computadores e que se presta à atividade "preparatória" para o trabalho, com capacitação e realização de oficina pedagógica da Secretaria de Educação; tem também uma sala de vídeo.

Prestam serviços um diretor, um vice-diretor, dois coordenadores pedagógicos, um para o período diurno e outro para o período noturno, um quadro de aproximadamente 65 professores e 15 funcionários administrativos e de apoio escolar, com um total de aproximadamente 80 pessoas.

Segundo o Coordenador Pedagógico do período diurno a instituição possui uma proposta pedagógica que é revista todos os anos e tem como premissa básica à integração com a comunidade.

Houve acesso à Proposta Pedagógica, que caracteriza a clientela como "carente", define seu nível social como "classe c" (não explicando o critério da definição), reconhecendo-a como pobre (sem também explicar o critério de pobreza), mas não a inclui em um quadro de pobreza absoluta ou de miseráveis (que também não explica). 


\subsection{Diretrizes da proposta de educação para a cidadania da escola pública}

No que tange à educação para a cidadania, o coordenador cita como suporte o programa oficial da Secretaria da Educação, que é o programa Escola da Família ${ }^{18}$ (que também aparece na proposta), afirmando inclusive que o programa teve um retorno positivo, pois após sua implantação, em que equipamentos da escola, destacando-se a sua quadra de esportes, foram abertas à comunidade, suas instalações físicas não sofreram mais violências, invasões ou depredações; refere-se também ao outro programa da Secretaria da Educação, que é o jovem cidadão, que trouxe uma participação maior dos alunos em projetos de leitura e em eventos teatrais, mas cujo principal avanço foi um projeto de Meio Ambiente, chamado de "Água Fonte de Vida", que mobilizou e integrou coordenação, professores e alunos em sua realização, com visitas em loco a fontes, nascentes e mananciais hídricos da região. Além dos programas oficiais não aparecem informações operacionais de como se desenvolve as aulas para a realização do processo de educação para a construção da cidadania. Nada mais foi apresentado ou acrescentado, além do aqui exposto.

\section{4. Época de realização da proposta da escola pública}

Não aparece no documento apresentado e não informou o senhor coordenador o período em que a proposta foi realizada, consta apenas que ela é revista todo início de ano letivo.

\footnotetext{
${ }^{18}$ O Programa Escola da Família é uma iniciativa que une mais de 5 mil profissionais da educação, 30 mil estudantes universitários e milhares de voluntários para criar uma cultura da paz, despertar potencialidades e desenvolver hábitos saudáveis junto aos mais de 7 milhões de jovens que vivem no Estado de São Paulo. O objetivo do Programa é a abertura, aos finais de semana, de cerca de 6 mil escolas da Rede Estadual de Ensino, transformando-as em centro de convivência, com atividades voltadas às áreas esportiva, cultural, de saúde e de qualificação para o trabalho. "Na informalidade da vivência cultural e da prática esportiva, o programa aproxima ainda mais professores, trazendo igualmente a comunidade para dentro da escola". Geraldo ALCKMFN GOVERNADOR do Estado de São Paulo Secretaria da Educação do Estado de São Paulo - Pagina da Internet disponível no site http://www.educacao.sp.gov.br/
} 


\subsection{Observação necessária}

Comparando-se as duas escolas e de modo geral e do ponto de vista dos professores (ver entrevista Prof ${ }^{a}$ S.L) é preciso dizer que as escolas particulares da periferia não pagam salários aos professores muito diferentes do que se paga nas escolas públicas, os vencimentos quase não apresentam diferenças. Observe-se ainda que a escola pública em relação ao pagamento de salários oferece segurança para os professores, eles sabem que sempre receberão no dia certo e que o maior ou menor salário, bem como o dia de receber não depende do número de alunos, nem do tipo de trabalho que desenvolvem em sala de aula; e por outro lado os professores sabem que na escola particular não sofrerão violências, que a indisciplina que enfrentarão, quando muito, será o excesso de conversa entre alunos, mas não serão ameaçados, desrespeitados ou xingados e nem terão bate-bocas com pais ou alunos. Procura-se sempre ouvir os professores, pois se sabe que a maioria leciona também na rede pública e segundo eles, os alunos das escolas particulares são mais educados do que os alunos da escola pública e, portanto é mais fácil lecionar. O normal ou ideal para os professores é lecionar nas duas redes.

\subsection{A escola privada - caracterização geral}

A escola colocou à disposição uma gama maior de peças, tais como o Regimento Escolar, os Planos de Cursos, o Plano Escolar e a Proposta Pedagógica. O mantenedor fez questão de contar a história da origem e evolução da instituição, o que facilitou o trabalho e acabou gerando informações mais detalhadas. Ela teve como precursor o Curso Ideal, que nasceu em 1979, como curso supletivo (atual Educação de Jovens e Adultos, EJA) e em 1989 conseguiu autorização para instalação e funcionamento com a denominação atual, mantendo os cursos de Educação Infantil, Fundamental, Médio, Técnicos e EJA.

A escola está instalada em um prédio com quatro pavimentos, possui 28 salas de aulas, 
laboratório de informática, salas para todas as dependências administrativas como diretoria, coordenadoria, secretaria, atendimento ao público, salão para eventos e atividades extracurriculares, anfiteatro, biblioteca com funcionário (não especialista) para atender os alunos, com cantina para alunos e refeitório para os funcionários, quadra coberta, módulo de brinquedos instalados em espaço coberto e funciona em três turnos: manhã, tarde e noite, contando atualmente com 1200 alunos. O quadro escolar apresenta 55 funcionários, com 40 professores, um diretor (sócio da mantenedora), um assistente de direção, uma coordenadora pedagógica, uma secretária, cinco auxiliares de secretaria e atendimento ao público, um arquivista e funcionário da biblioteca, cinco inspetores de alunos, sendo que os serviços de limpeza e segurança são terceirizados.

Segundo seus mantenedores, ao longo do tempo a equipe escolar desenvolveu uma consciência, que lhe serve de parâmetro para sua atuação voltada para o resgate da cidadania, nos casos em que ela existe, mas está adormecida (basicamente junto ao aluno do EJA) e construção da cidadania junto às crianças e adolescentes que atende, crendo que a cidadania é um importante mecanismo para a intervenção e transformação da realidade do meio em que se vive.

Portanto, segundo orientação da mantenedora, procurando atender aos dispositivos da Lei de Diretrizes e Bases da Educação Nacional (Lei 9394/96), que estabelecia, quando foi promulgada, a necessidade de reformular o Regimento Escolar, os Planos Escolares e de formular uma Proposta Pedagógica; a comunidade Escolar foi convocada e com participação efetiva do corpo técnico-pedagógico, foi elaborada uma proposta pedagógica, observando os princípios de que,

A proposta pedagógica deve refletir o melhor equacionamento possível entre recursos humanos, financeiros, técnicos, didáticos e físicos, para garantir (...) formas de organização da aprendizagem e de inserção da escola em seu ambiente social (...) antes de tudo deve ser simples: O projeto pedagógico da escola é apenas uma oportunidade para que algumas coisas aconteçam e dentre elas o seguinte: tomada de consciência dos principais problemas da escola, das possibilidades de solução e definição das responsabilidades coletivas e pessoais para eliminar ou atenuar falhas detectadas ".(Parecer CEB/CNE 15/98, pgs. 32 e 33)". 
A proposta pedagógica coloca que do ponto de vista social e econômico a escola está no epicentro de uma região com mais de um milhão de habitantes, limitada por linhas de contradição: da pobreza (que a proposta pedagógica, não define) a um padrão de vida de classe média baixa (também não definido), por isso com todas as marcas de violência que as carências geram. Continua, afirmando que a instituição é coerente com sua própria história e que tem como objetivo permanente a busca de mecanismos que lhe permitam intervir e ser um agente de mudanças desta realidade, visando a melhoria da qualidade de vida da comunidade na qual está inserida.

A proposta caracteriza a clientela como heterogênea, afirmando que atende aluno oriundo de família estruturada, com bom poder aquisitivo em relação ao meio em que vive e que não precisa trabalhar para completar o orçamento doméstico; o jovem que já está integrado ao ambiente de trabalho, que é peça complementar do rendimento familiar e que após o turno escolar irá cumprir um turno de trabalho e que tem pela frente alguns casos presumidos na Lei de Diretrizes e bases da educação Nacional, que é o jovem defasado, aquele aluno que precisa de aceleração de estudos, e que no contexto geral atende alunos dentro da idade escolar adequada.

Na identificação de problemas caracteriza como um dos mais graves, a questão das drogas e da violência. Aqui com a observação da direção de que o professor tem uma visão carregada de ideais, chegando muitas vezes a ser ingênua e acredita sempre na ação educativa, o que o leva a formular propostas que lhe pareçam ideais, mas as responsabilidades da direção desenvolvem também a noção de limitação e aprende-se ao participar da direção da instituição escolar que existem enfrentamentos que não se pode fazer ${ }^{19}$ e que, portanto, existem objetivos que praticamente não podem ser atingidos.

\footnotetext{
${ }^{19}$ Para ficar claro do que se está falando, acrescenta-se que quando a direção da instituição constatou a presença de traficantes com ponto de tráfico em um posto de gasolina ao lado do colégio e que eles já haviam envolvido dois alunos da instituição de 12 e 13 anos, entrou-se em contato com a polícia e foi-se orientado a não entrar em
} 


\section{7. Época de realização da proposta da escola privada}

A Proposta Pedagógica foi realizada originalmente na segunda quinzena de janeiro de 1999, durante o período de recesso escolar, quando os professores foram convocados para esta atividade.

Ressalte-se que por orientação da mantenedora, a instituição procura contratar professores que nasceram na região, ou que nela foram criados e ou que moram nas proximidades, porque considera que a falta do professor ao trabalho traz grande prejuízos. Também justifica estas diretrizes o desejo de contar com professores que conheçam a clientela e a sua realidade o que pode contribuir para a melhoria da qualidade do trabalho pedagógico. Isto faz que os professores da instituição sejam oriundos das diversas vilas do entorno da escola, sendo conseqüentemente membros da comunidade e tendo, portanto, ligações com a região e conhecendo-a de sobejo, bem como seus problemas, com os quais conviveram a maior parte de suas vidas.

Assim os professores buscaram atender ou contemplar os diversos objetivos propostos em função da comunidade em que vivem e em que o Colégio está inserido e desta forma a proposta pedagógica nasceu como resultado do alinhamento da visão de cada um. O consenso final foi o de que era urgente uma ação educativa voltada para a construção da cidadania.

Resumindo, a proposta repete os dizeres que aparecem em documentos oficiais, como na Lei de Diretrizes e Bases da Educação Nacional, parecer CEB/CNE 15/98 e Resoluções

\footnotetext{
choque com os traficantes e apenas orientar os pais dos alunos em como proceder para resolver o problema dos seus filhos e orientar os alunos para manterem-se longe do local. A polícia em um primeiro momento mostrou-se absolutamente inoperante, foi necessário recorrer-se a instâncias superiores, houve algumas diligências e a situação hoje é a mesma, os traficantes ausentaram-se temporariamente, substituíram os elementos conhecidos e voltaram com novos membros, até então desconhecidos. Os meninos foram cooptados jogando futebol em um terreno baldio perto de suas casas e não nas proximidades do colégio e segundo eles, caso não colaborassem as suas famílias sofreriam as consequiências. Indagados quanto a que conseqüências seriam estas, responderam que seus pais seriam mortos, o que os deixou apavorados. Isto demonstra o quanto o Estado está ou é ausente da periferia.
} 
CEB/CNE 02 e 03/98, que estabelecem os princípios gerais que norteiam a educação nacional, após o que, conclui que a instituição deve ser:

1) um instrumento capaz de transformar a realidade de seu meio;

2) ferramenta que em curto, médio e longo prazo, possa implantar no seio da comunidade a consciência de cidadania e fazê-la participar das benesses do desenvolvimento cultural, cientifico e tecnológico;

3) veiculo que faça da educação um processo eficaz de desenvolvimento cultural, econômico, político e social;

4) mecanismo que garanta sua liberdade e responsabilidade, na formulação de sua proposta pedagógica e com protagonismo de todos os elementos diretamente interessados, em especial dos professores.

\subsection{Diretrizes da proposta de educação para a cidadania da escola privada}

Sabedores que existem inúmeras dificuldades, direção, coordenação e professores chegaram à seguinte conclusão de como deveria ser formulada uma ação para o desenvolvimento de uma consciência sensível à cidadania nos diferentes níveis de ensino, traçando o seguinte caminho:

1) começando na Educação Infantil, a partir da pré-escola até as quatro primeiras séries do ensino fundamental, desenvolver um projeto de respeito ao meio ambiente e de educação no trânsito, inclusive com referências à lei de proteção ao meio ambiente;

2) da quinta a oitava séries, aprofundar a educação sobre meio ambiente e trânsito, ensinar o Estatuto da Criança e do Adolescente, em seguida o Código do Consumidor, o Estatuto do Idoso e Noções de Direito Constitucional;

3) no ensino médio recorrer à evolução histórica da cidadania. Começar na origem e formação das sociedades humanas, passar pela cidade estado grega, demonstrar o 
surgimento e desenvolvimento da cidadania política; a sociedade feudal e o surgimento da burguesia, o renascimento, o iluminismo, a Teoria Geral do Estado e o desenvolvimento dos direitos civis; o Estado liberal, filósofos contemporâneos, Hegel, Marx, os direitos sociais e a nossa Constituição cidadã de 1988.

4) valer-se do fato de que na matriz curricular desde o pré consta Filosofia, para estar sempre recorrendo ao longo de qualquer dos cursos oferecidos ao conceito de cidadania, à legislação e instituições que lhe dão amparo.

É necessário repetir que não houve preferência pela análise da escola particular, mas que os documentos oferecidos ofereceram um maior número de dados e de detalhes e assim procurou-se explorar ao máximo o material disponibilizado. 


\section{OS ATORES FALAM DE SUA EXPERIÊNCIA}

\subsection{Observações preliminares}

Foram sujeitos deste estudo três alunos da escola pública, com idade entre 17 e 18 anos matriculados na primeira, segunda e terceira séries do ensino médio e quatro alunos da escola particular; também com idade entre 16 e 18 anos e matriculados nas segunda e terceira séries do ensino médio, em um total de sete alunos; um coordenador pedagógico e três professores da escola pública e um coordenador pedagógico e três professores da escola privada. No total foram dois coordenadores pedagógicos e seis professores, que somados aos sete alunos perfizeram um total de 15 participantes das instituições escolares e mais seis pais de alunos e membros da comunidade, sendo três de cada instituição, perfazendo um total de vinte e um participantes.

O critério de amostragem para análise qualitativa não é numérico, pois segundo afirma Minayo (1994, p.43) "a amostragem boa é aquela que permite abranger a totalidade do problema investigado em suas múltiplas dimensões". Foram feitas algumas indagações consideradas importantes, tais como:

a) A instituição escolar pública ou privada está realmente empenhada, ou tem como objetivo primordial trabalhar a construção da cidadania e prática da democracia em meio tão adverso como a periferia?

b) O trabalho da instituição escolar seja a pública ou a privada, tem sido eficaz, conta com apoio e encontra respaldo do poder público e mesmo da comunidade na realização do trabalho dirigido para a construção da cidadania e prática da democracia? 
c) O que realmente pode ser feito para a educação para a cidadania e para a prática da democracia? É possível educar para o exercício da cidadania e prática da democracia na periferia das grandes metrópoles? A ação das instituições tem tido o retorno esperado?

d) Existe lucidez e preparação por parte do professor para perceber, sentir e trabalhar a construção da cidadania em situação tão adversa como a da periferia?

e) Como o professor percebe e trabalha a cidadania no contexto periférico? O que e como ele faz para dar sua contribuição? Existe retorno no trabalho que ele faz?

f) Como o aluno e também o pai do aluno percebe sua cidadania e como se sente em relação aos seus direitos como cidadão? Quais são suas perspectivas de vida considerando o quadro adverso da periferia?

g) Os alunos conseguiram entender a educação que lhes foi dada para utilizá-la em função do exercício da cidadania?

h) Como tem sido o papel do poder publico, das instituições, dos professores e dos alunos em relação à cidadania?

Os dados foram ordenados a partir de transcrição das gravações, da releitura e organização do material, comparando-se as entrevistas e classificando-se tópicos coincidentes e divergentes das falas, que pudessem balizar a compreensão da ação desenvolvida por todos participantes.

Na escola pública foi realizada a entrevista com o Coordenador Pedagógico do período diurno, com duas professoras que lecionam apenas naquela instituição e uma terceira professora que leciona na escola pública e na escola privada e também com quatro alunos. Os professores foram escolhidos pelo coordenador, segundo ele pelo maior envolvimento que tinham com o tema, e os alunos foram chamados na sala de aula, indicados pelo coordenador e professores. 
As entrevistas, após diversas visitas realizadas ao estabelecimento, foram realizadas em dois dias, no primeiro com o coordenador e uma professora, no segundo com mais duas professoras e os três alunos e ocorreram na sala do coordenador, sem que ele estivesse presente, todavia ele fazia as apresentações e participava de uma conversa preliminar até sentir que o entrevistado estivesse mais à vontade. Os entrevistados aqui são assim identificados:

\section{a) Coordenador}

1) D.O, Licenciado em Pedagogia e Geografia, pela UNICASTELO, é o Coordenador Pedagógico do período diurno;

\section{b) Professores}

1) C.G. D. S., licenciada em Letras, ministra aulas apenas na rede pública;

2) R.D.C., com Habilitação para o Magistério em nível de $2^{\circ}$ de Grau, ministra aulas em series iniciais;

3) S.L., licenciada em História, pela UNICASTELO, é professora nas duas instituições.

\section{c) Alunos}

1) I. G, aluno do $3^{\circ}$ ano do ensino médio, com 18 anos de idade;

2) D. V. D. S. aluno do $1^{\circ}$ ano do ensino médio, com 18 anos de idade;

3) E. D. S., aluna do $2^{\circ}$ ano do ensino médio com 17 anos de idade.

\subsection{Falam os atores educativos da escola pública}

É preciso esclarecer que foram listados alguns tópicos, sobre os quais foram feitas algumas constatações e comentários, mas não a análise da fala, que foi realizada na seqüência, após a exposição das entrevistas.

Acredita-se que os seguintes tópicos extraídos das entrevistas realizadas na escola pública tenham grande importância para uma análise mais acurada. 


\section{Tópicos da fala do coordenador da escola pública}

Percebe-se através da fala integral e não apenas nos pontos que aqui se reproduz, que para o coordenador da escola pública, o princípio de tudo é a dificuldade econômica, o desemprego e separação dos pais e a própria desestruturação familiar. Na medida em que ele chama os pais para falar dos filhos, acaba ouvindo quais são na realidade as dificuldades dos pais, que acabam afetando o filho. Ele fala então em estrutura familiar; na separação e na briga dos pais pela posse dos filhos, atribuindo tudo ao desemprego na região. Para ele o reflexo no aluno são problemas emocionais que ele chamou de psicológicos, dificuldades, agressividade e indisciplina. Fala inclusive em briga pela posse dos filhos, em tentativa de tirar as crianças da escola e levá-las para outros lugares, sem termo de posse ou mandado judicial.

Em determinado momento coloca também a questão da ausência dos pais, que ele convoca e muitas vezes tem que buscar os pais em casa, uma vez que eles não comparecem e que falta apoio da família que resulte em uma ação que colabore com a disciplina na escola. "Muitas vezes temos que chamar uma, duas ou três vezes o pai, para tratar até de problemas de indisciplina. Eles demoram em vir na escola e nós temos que mandar alguém ir lá buscar" .(D.O. Coordenador escola pública).

A rotina de problemas tem como essência a agressividade e o desrespeito para com os professores. "O maior problema, não é que os alunos sejam agressivos, que tragam armas, isto não, mas é o desrespeito para com os professores"... (D.O. coordenador escola pública)

O professor, ainda segundo o coordenador, por uma questão de sobrevivência precisa lecionar em diversos lugares e acaba não tendo tempo para se preparar, na prática apenas cumpre horário, não tem como avaliar sua atuação em sala de aula e nem sua própria ação no dia a dia, sendo uma marionete movida por circunstâncias momentâneas "Porque o professor começa a trabalhar de manhã e vai parar onze horas da noite em busca de 
recursos financeiros. (...) Ele faz aquilo do momento, mas não dá para ele reavaliar o que ele está fazendo em sala de aula".(D.O. coordenador escola pública).

Os cursos de capacitação, segundo o coordenador, são dados por quem não conhece a realidade da periferia e, portanto, não tem efeito prático algum para a educação na periferia. "Nós temos muitos tecnocratas que ditam as regras e quando você vai ver a biografia dele e o dia a dia dele é uma outra realidade, diferente daqui da periferia".(D.O.Coordenador escola pública).

Nesta avaliação transparece o fato que o governo procura investir em cidadania e chega inclusive a criar alguns projetos, mas admite que faltam recursos, que falta dinheiro para que possa haver um trabalho melhor, dando a entender que seria preciso recursos econômicos para oferecer capacitação profissional. "Na verdade o governo tem até tentado investir na escola, criando alguns projetos para que o aluno possa se integrar mais na escola, a questão do projeto água a fonte da vida. (...) Se a escola não tem muitos alunos não vem muito dinheiro".(D.O.coordenador da escola pública).

O aluno na periferia é presa do desânimo e da falta de perspectiva, novamente atribuindo este quadro à falta de empregos. "Os alunos perderam um pouco a visão do que querem... quem sabe um pouco é porque o governo não ajuda, não tem emprego".(D.O. coordenador da escola pública).

Outro aspecto que parece importante para a questão da cidadania é a formação dos pais "a maior parte dos pais dos nossos alunos cresceram e formaram-se no período ditatorial, o que implica em uma formação complicada na questão de democracia”. Este parece ser um fator que dificulta a compreensão e o exercício da cidadania, uma vez que a participação da comunidade e da família é extremamente importante na aprendizagem do aluno, que será o futuro cidadão. "a maioria deles limita-se a votar e ser votado, se não existe uma clara compreensão da democracia a prática da cidadania fica prejudicada". 
Um ponto que chama a atenção e é preocupante foi a colocação feita pelo Senhor Coordenador "Pela lei sabemos que não podemos sonegar informações, temos que deixar nossos alunos cientes dos direitos que eles têm, embora muitos diretores fiquem preocupados em abrir muito, porque, conforme ensinamos, há cobranças”, pois isto parece indicar uma tendência em alguns gestores ou administradores escolares em não ensinar para não ter preocupações, não ensinar para não ser incomodado.

No trecho em que coloca as dificuldades do professor "o governo está tentando fazer o papel dele e então fica uma coisa assim o aluno finge que aprende e o professor finge que ensina e nós temos uma democracia pela metade". Transparece que o governo tem buscado propiciar uma educação voltada para a cidadania e prática democrática, mas não tem conseguido formular uma proposta ou planejamento adequado, que passe inclusive pela valorização do professor, sem o que parece que não vai conseguir articular o que propõe com o que é praticado.

\section{Pontos que chamaram a atenção da fala da professora C.G.D.S. da escola pública}

Ela acha que é muito difícil exercer os direitos de cidadão na periferia e que o jovem da periferia é discriminado pelo simples fato de morar na periferia e que a primeira grande barreira começa na tentativa de arrumar o primeiro emprego. "É muito difícil para ele aí fora. Exercer os direitos de cidadania. (...) Arrumar seu primeiro emprego, sofre discriminação por morar na periferia, que é o primeiro obstáculo na vida dele". (C.G.D.S. Professora da escola pública). A tônica da discriminação surge logo no princípio da fala.

Acredita que o governo não investe adequadamente no jovem da periferia, fato que leva o jovem a descrer não só no governo, mas também na própria escola, coloca que a descrença do jovem começa colocando em dúvida o princípio da igualdade, "mas é difícil, o aluno questiona sempre, afirmando que existe diferença de direitos para os que exercem o 
poder e para os ricos". A fala continua revelando dados de extrema importância, indicando que a comunidade periférica caminha para um ponto de saturação "falam em arrogância da autoridade, quando, por exemplo, um juiz contraria propositalmente o sentimento do Brasil inteiro e solta um criminoso hediondo". A fala mostra que existe sintonia entre o que os meios de comunicação divulgam e o que a sociedade pensa "que a imprensa, a televisão, mostra diariamente que ele é monstruoso, mas o juiz solta e todo mundo sabe que a mesma lei que ele usa para soltar pode manter o bandido preso". As criticas que antigamente ficavam restritas à classe política são estendidas também ao judiciário e, sobretudo começa a haver uma clareza de entendimento, "acham que ele faz isto para humilhar a sociedade, que em sua maioria é formada por pobres e também quando todo muito critica, mas as autoridades resolvem aumentar seus enormes salários”. Ora, esta consciência pode levar a um sentimento de revolta e de agressão à autoridade.

O sentimento do principio de revolta parece ser irreversível "o governo deixa muito a desejar em investimento no jovem da periferia, por isto que muitas vezes ele fica descrente até mesmo dentro da escola". (C.G.D.S. Professora da escola pública).

Admite que não existe respeito pelos direitos sociais na periferia, sobretudo no que tange ao atendimento na área de saúde, acreditando que é muito difícil até marcar uma simples consulta, fator que contribui para fazer com que o jovem não acredite em nada influindo diretamente na sua falta de perspectiva de vida. "Eles se sentem descrentes de tudo, não querem saber mais de nada, não têm uma perspectiva de vida, a grande verdade é que o aluno não tem perspectiva de vida". (C.G.D.S. Professora da escola pública).

Entende que o retrato que os órgãos governamentais fazem da educação, bem como o próprio discurso oficial não encontra correspondência em investimentos reais e necessários na educação do jovem na periferia. Acha que o governo passa coisas na televisão que não pratica e que o professor muitas vezes tem que lançar mãos de recursos próprios para ter 
materiais adequados para dar uma boa aula. "Passa coisas na televisão que não existe na escola e nem na sala de aula. No dia a dia da convivência com o aluno não há o que eles mostram (...) E ficamos ouvindo aqueles professores que já saíram da sala de aula". (C.G.D.S.Professora da escola pública).

\section{Itens importantes da fala da professora R.D.C. da escola pública}

Foram percebidos na totalidade da fala e não apenas nesta reprodução parcial que se faz, o medo do aluno em falar sobre o que está acontecendo na comunidade. Faz uma observação de que ao se tentar saber do aluno a causa do seu medo em relação à comunidade, que a comunidade questiona e procura não deixar ninguém se envolver em seus assuntos "O aluno tem medo de questionar, tem medo muitas vezes de colocar o que ele está pensando e mesmo o que está acontecendo na comunidade e se você tentar se envolver muito com a situação, até mesmo a comunidade te questiona".(Prof. R.D.C. Professora da escola pública).

A colocação de que "se eu abranger um assunto maior da comunidade mesmo, no caso a comunidade me questiona, o aluno e a comunidade de ontem não, o aluno e a comunidade hoje têm muito medo", nos faz refletir e perguntar porque e do que a comunidade tem medo? Os recentes ataques do PCC, do crime organizado, parece responderem esta pergunta. ${ }^{20}$ Diz que o Estado tem o objetivo de mandar o aluno para a escola, dando a entender que acaba ai sua responsabilidade, não se preocupando com a qualidade da educação e com o fato de que o aluno não se importa em aprender. Não coloca a culpa desta situação no governo, acredita que os alunos estão vindo de famílias sem perspectivas, sem objetivos ou meta de vida e que nesta circunstância fica difícil

\footnotetext{
${ }^{20}$ A entrevista com este grupo de professores foi realizada em dezembro de 2005, antes dos ataques do crime organizado. O que demonstra que a comunidade periférica sabia o que estava acontecendo e que somente as nossas autoridades constituídas que estão à frente do governo e dos órgãos governamentais não sabiam.Muito estranho.
} 
educar, acredita inclusive que a escola faz sua parte no que tange ao processo de educar para o exercício da cidadania "O Estado quer o aluno dentro da escola, o importante é ter a clientela dentro da escola, está certo, quanto mais aluno melhor....(...) Estão vindo de famílias sem perspectivas, sem objetivo, sem meta". (Prof. R.D.C. Professora da escola pública). Esta observação nos leva a olhar a questão da cidadania e da democracia como uma dificuldade oriunda do seio da família e da comunidade.

Acha que o poder público tem uma visão diferente sobre o cidadão da periferia e de áreas mais nobres, havendo certamente discriminação em relação ao cidadão da periferia. Acha que na periferia a situação de medo já está cristalizada. Ela mesma admite que já teve muito medo e que acabou superando este medo em cursos de capacitação."Não, não existe respeito à cidadania. (...) Nos jardins você vê pessoas passando correndo, fazendo exercícios e é normal, aqui, ver alguém correndo, ou roubou ou está sendo assaltado!". (Prof. R.D. C. Professora da escola pública). Novamente a percepção de discriminação.

Acredita que existe o problema de desestruturação familiar, que a separação de pais realmente prejudica as crianças, mas que a escola e os professores têm que enfrentar esta situação com naturalidade e que isto não pode ser motivo para que não se faça um bom trabalho. Acredita que a escola pública ainda é uma boa escola "Na maioria das vezes trabalhei com crianças filhas de pais separados". (Prof. R.D.C. Professora da escola pública).

Pontos interessantes da fala da professora S.L (que leciona na escola pública e na particular).

Ela entende que nem a escola pública e nem a particular trabalha a educação para a cidadania. Acha que para o Estado o aluno é somente um número e para a escola particular um valor econômico ou uma unidade financeira. Acha que a educação para a cidadania fica resumida a leitura de livros. 
Não conseguiu relacionar a leitura de um livro de capoeira indicado por órgãos oficiais da Secretaria de Educação com o tema formação em educação para a cidadania. "O que é capoeira, cito este tema, pois estive em contacto direto com ele (...) Mas obriga-se o aluno a ler, faz-se avaliação e o assunto termina por ai, ou seja, como a cidadania pode ser discutida e resumida em um livro de capoeira?". (S.L. Professora da escola pública e da particular). Apesar desta incompreensão, leciona disciplinas voltadas para a formação da cidadania, o que pode indicar que aquilo que transparece em diversas falas, a de que o Estado tenta fazer sua parte, é uma realidade, mas que ele não sabe como fazer.

Acha a periferia carente de tudo o que demonstra em sua opinião que o governo não tem preocupações reais com a cidadania, sobretudo no que tange a direitos na área da saúde e educação, deixando-a realmente abandonada. Mas que de forma geral não existe atendimento aos direitos sociais na periferia. Que todos na periferia são desrespeitados como cidadãos. "Nós aqui na periferia não temos equipamentos sociais, ou seja, os hospitais, postos de saúde, escolas públicas (...) Os políticos lembram-se desses cidadãos apenas na época das eleições".(S.L. professora da escola pública e da privada).

Entende que na escola pública a maior dificuldade para que se desenvolva um projeto sistemático elaborado para atender a realidade típica de cada situação que apareça para a própria escola, não ocorre por causa da rotatividade de professores, com o sistema de atribuição de aulas no início de cada ano, existe uma constante troca de professores, pois nenhum quer lecionar nos lugares mais distantes da periferia. "A escola nunca é a mesma ou seja, professores, principalmente, todo ano mudam-se os professores, todo ano as aulas vão para atribuição nas Diretorias Regionais de Ensino e mudam-se os professores”.

Acredita que o aluno tem como conceito de cidadania apenas o seu próprio direito, não conseguindo enxergar o direito dos demais membros de sua comunidade. Para ela são necessárias mudanças no Estatuto da Criança e do Adolescente (ECA), porque como ele é 
fator que estimula a indisciplina na escola e o desrespeito à Lei. "O ECA. Ele precisa ser revisto, muito do ali colocado não condiz com a realidade, mas as pessoas o levam ao pé da letra quando o mesmo é para beneficiá-lo"..(S.L. Professora da escola pública e da privada).

\subsection{Síntese dos depoimentos dos professores da escola pública}

Na escola pública tanto professores como alunos em um primeiro momento mostraramse reservados e com resistência à entrevista, somente após conversa descontraída entre entrevistador e coordenador, com os entrevistados é que eles acabaram saindo da defensiva. Deve-se inicialmente ressaltar que os professores demonstraram consciência sobre os conceitos atuais de cidadania.

Ao observar-se o material colhido, encontrou-se uma riqueza de informações, que: tornou possível conhecer a realidade da educação em condições adversas e saber até onde a educação voltada para a construção da cidadania pode atingir seus objetivos e quais são realmente os problemas que jovens, instituições, educadores e comunidades enfrentam no cotidiano da periferia da grande metrópole. Percebem-se um conjunto de coincidências dentro de uma mesma instituição e às vezes algumas contradições, produto do olhar diferenciado de cada protagonista.

Um exemplo citado pelo coordenador foi que se, por exemplo, o professor quiser falar do maior problema que assola a região que são as drogas, os alunos já acham que o professor está dizendo que eles são os drogados e reagem prontos para a agressão. Percebese que a violência é algo tão comum, que o coordenador passa a achar que agressividade é não portar armas, seus alunos reagem querem agredir os professores, mas não são agressivos porque não portam armas.

Dentro deste contexto, parece absolutamente natural a professora R.D.C. declarar que 
já teve medo, muito medo e que o aluno não gosta de falar da comunidade e nem a comunidade quer falar sobre si mesma, sobre seus problemas cotidianos.

Por seu lado a professora C.G.D.S., queixou-se da falta de material para dar uma boa aula e fez uma crítica à política pública de capacitação do professor, afirmando que a realidade é diferente daquilo que o Estado tenta fazer a sociedade acreditar. Concluiu sua fala dizendo que o jovem (aluno) não tem perspectiva de vida, o que também o coordenador já havia dito e ambos falam da falta de investimento na periferia e no desemprego como um fator de desestimulo.

Não restam dúvidas que dentro deste quadro deve ser muito difícil motivar o aluno para que ele aprenda e, sobretudo, para que ele confie nas instituições e no poder público, sobretudo quando ele acredita que ação do poder judiciário é arrogante e toma decisões para contrariar e humilhar a sociedade.

A fala de S. L., que é uma professora licenciada em História e que teceu críticas ao ECA, pareceu contraditória em relação às demais falas, todavia vista no conjunto, ela parece ser apenas uma crítica ao Estado, que é em sua visão, ausente da periferia e sendo ela um membro da comunidade periférica, reage com indignação acreditando que o Estado parece ter deixado a violência dominar toda a região, o que transforma todos os moradores da periferia em vítimas. A criança, vista conforme conceito popular como "mal educada" foi associada ao aluno, pois "quem causa problema no condomínio, causa problema também na escola". Na realidade a criança da periferia, quando tem estrutura familiar é criada reclusa em casa e nos poucos momentos em que se solta, o pequeno espaço do condomínio, bem como a escola vira para ela um clube social, um ponto de encontro com amigos, mas o seu direito de ser criança acaba sendo visto como um problema. Realidade triste, mas é a realidade da periferia, em que todos são reféns do medo e da violência.

O coordenador não lamenta, não critica, angustia-se, achando que é preciso um 
mecanismo para acabar com a falta de perspectiva dos jovens e se empenha como educador em buscar alternativas e insiste em dizer que a escola precisa de parcerias (o que por si só demonstra a ausência de ações positivas do Estado), de mecanismos de capacitação do jovem, para qualificá-lo e inseri-lo no mercado de trabalho. Sua angustiante preocupação é com o desemprego na região, o que segundo ele pode empurrar o jovem para a droga e o tráfico.

O desemprego, conforme se pode perceber, significa ameaça permanente de privações e as relações familiares tornam-se extremamente instáveis quando a miséria ameaça entrar pela porta da frente. Dentro do conceito básico de um sistema de ações sociais e no chamado mundo da vida, que abrange a cultura, as normas de conduta ética, os códigos de integração e socialização e as identidades individuais, quando alguém não consegue sustentar a própria família tende a entrar em depressão, frustração e fragilidade psicológica, que se estende a toda família; é quando costuma ocorrer a fuga para as drogas, primeiro às drogas licitas como o álcool e em seguida as ilícitas e assim a família começa a ruir, a autodestruição e a violência, neste quadro chegam para ficar. As perspectivas da existência digna desaparecem.

Fica a impressão que o quadro mostra-se absolutamente adverso, que existe um problema de omissão dos pais dos alunos e também um quadro negativo muito grande de alunos com famílias desestruturadas, mas que contra todas as dificuldades persiste a vontade dos educadores de superar obstáculos, porque eles mesmos entendem que a periferia recebe um tratamento discriminatório e acreditam que só a educação poderá superá-los.

\subsection{A educação para a cidadania na visão dos alunos da escola pública}

Abaixo seguem alguns tópicos sobre o que disseram os alunos da escola pública, onde 
foram selecionados alguns itens considerados importantes para posterior análise.

\section{Inicia-se com a fala do aluno I.G., com 18 anos de idade.}

Ele faz uma afirmação que parece ser um sentimento presente no cidadão da periferia: “Ser respeitado não, porque tem muita discriminação, né cara, não só por mim, mas por varias outras pessoas tipo racismo, aqui você é visto como inferior" (I.G. Aluno da escola pública).

Ele acredita que cidadania é igualdade de direitos e não acha que na periferia haja respeito pela igualdade de direitos e nem acredita que haja obediência à lei. Na medida em que avança o diálogo, ele vai passando a impressão de que o desrespeito ocorre por parte das autoridades constituídas e, sobretudo por parte da polícia. Ele acha que a escola cumpre seu papel e atribui os problemas a maus políticos e ao governo. "Saber quem colocar lá na presidência pra governar isso aqui direito, tá... nada mudou, tá tudo no mesmo canto e vai só piorando, piorando, piorando". (I.G. Aluno da escola pública).

Ele deixou transparecer que não é respeitado como cidadão, que existe muita discriminação na periferia e que a polícia é um fator de desrespeito e humilhação do cidadão da periferia."Tipo aqui... é, na periferia, aqui eles já pegam o pessoal subindo na escola já te enquadra e deixa um bom tempo lá enquadrado ${ }^{21}$, lá nos jardins não, os policiais já chegam perguntam, tem outro tipo de lidar com as pessoas de lá".(I.G. Aluno da escola pública)

Ele acredita que para haver cidadania é necessário que se cumpram as leis e que a vida só está piorando e que a visão do governo em relação à periferia é de um lixão que vai se acumulando. "E aqui...tem um pouco mais de lixão pra gente, vai cada vez mais se amontoando se transformando em favela". (I. G. Aluno da escola pública).

\footnotetext{
${ }^{21}$ Enquadrar significa colocar a pessoa sob a mira das armas, mandar que encoste as mãos na parede ou deitálas no chão com as mãos estendidas acima da cabeça, apalpá-las para revistá-las e como forma de humilhação mantê-las durante muito tempo nesta posição. Normalmente isso não é feito com os que transgridem a lei, porque estes reagem, submete-se a este tratamento apenas pessoas de bem que são impotentes diante desta ação humilhante da polícia. Daí a fala do aluno "e deixa um bom tempo lá enquadrado".
} 
Todavia o aluno tem um conceito crítico objetivo "a democracia que é o poder da maioria do povo e o pobre é maioria, ai você que as coisas estão erradas", ele consegue entender com clareza a distorção que é a prática da cidadania e da democracia na periferia.

\section{Alguns dados da fala do aluno D.V.D.S. da escola pública.}

Ele acha que o cidadão da periferia é tratado de forma diferente de um cidadão de área mais nobre da cidade e não demonstra clareza de idéias. "O meu conceito de cidadania? é a partir da escola... de forma geral...(...) Muitos funcionários públicos também que nem a polícia coisa assim deveria agir igual, entendeu..(...) Isso. Igualdade".

Não tem perspectiva de futuro. "Um futuro, bom o futuro de um cidadão trabalhador, né, que esteja em nível compatível a qualquer um, não sei, ainda não tenho como explicar sobre isso não, sobre a minha.....ainda não tenho uma noção clara a respeito do meu futuro". (D.V.S. Aluno da escola pública).

O depoimento do aluno pode demonstrar um estado ou sentimento de confusão que é comum na periferia, e que pode ser a semente da insatisfação que se revela no sentimento de crítica aos detentores do poder. O grande diferencial para ele é não usar drogas "eu ajo como cidadão e sou respeitado pelo cidadão normal, como cidadão também, porque eu não uso droga nem nada, né”. Infere-se daí que o uso de drogas pode ser algo absolutamente comum entre os jovens da periferia e o fato de não usar diferencia-o dos demais, dando-lhe a qualidade de cidadão.

\section{Alguns aspectos da fala da aluna E.D.S, da escola pública, com 16 anos de idade.}

Ela fala sem medo de problemas que os outros são reticentes, que são violência e drogas, atribuindo tudo ao desemprego. Mesmo com tão pouca idade a preocupação é com o trabalho, com emprego. "O uso de drogas, muitas vezes de violência, jovens que muitas vezes não tem oportunidade de trabalhar, e por isso acabam, não que isso seja a maior influência pro jovem, não, mas uma boa parte delas é a falta de emprego". (Aluna E.D.S da 
escola pública)

Ao contrário dos outros, a aluna tem perspectiva de vida e futuro. "Eu tenho uma, expectativa que, possa vir a melhorar né, porque...tenha mais empregos", (aluna E.D.S. da escola pública)

Mas como os outros alunos, também entende que a periferia é discriminada e que as melhores oportunidades de trabalho não acontecem na periferia, também atribui o problema ao Estado, que não cuida adequadamente da periferia. "Não pode recorrer muitas vezes à prefeitura porque nunca dá, tem vários projetos que contavam como indo, mais não, nada a ver. (...) o Estado já vê isso no dinheiro, então, já dá mais oportunidade pra quem tem dinheiro". (E.D.S Aluna da escola pública).

É importante observar que a educação continua sendo na periferia a estrada da esperança "Boa vontade, oportunidade, uma boa educação". (E.D.S Aluna da escola pública).

\subsection{Síntese da opinião dos alunos da escola pública}

Nestes dados observados de forma assistemática entendeu-se que os alunos da escola pública de forma geral têm um conceito de que cidadania é igualdade de direitos e um conjunto de direitos e deveres, embora não tenham definido os conceitos históricos de cidadania. Entendem a necessidade de igualdade, mas sentem a desigualdade, entendem os conceitos de cidadania e democracia de forma prática, quando criticam a exclusão do povo nas decisões que afetam a vida de cada um, "eles ensinam muito bem e a democracia que é o poder da maioria do povo e o pobre é maioria, ai você que as coisas estão erradas" (I.G. aluno da escola pública). Pois percebe o erro no tratamento discriminatório aplicado pela polícia na periferia e na qualidade de vida que a periferia não tem.

Todos os alunos sentem e percebem o processo de discriminação, de que a periferia é 
vítima, todos sentem o peso do tratamento de subcidadão. As reações é que são diferentes. Fica evidente que o maior instrumento de discriminação que o Estado tem e usa é a polícia, possivelmente porque ela é visível, ela é percebida e identificada com o governo.

O aluno I.G. com 18 anos de idade exprime o sentimento amargo de impotência ao tratamento discriminatório que a polícia aplica aos jovens da periferia, sentindo-se vítima da violência de quem tem a missão institucional de protegê-lo. Coloca com propriedade a questão "aqui tem um pouco mais de lixão pra gente". Demonstra descrença no poder político, ausência de perspectiva de vida e o sentimento de necessidade de mudanças, pois o quadro atual é extremamente adverso. Na fala dos jovens fica claro que é preciso mudar, que é preciso começar tudo de novo, que eles não estão satisfeitos com a realidade do mundo que os cerca.

Não restam dúvidas que para qualquer um nesta situação é muito difícil ter confiança no futuro, quanto mais para um jovem ainda em processo de formação.

O aluno D.V. S. mostra-se extremamente confuso, declara não ter uma noção clara de seu futuro, também fala do tratamento desigual que a polícia dá ao jovem da periferia e o sentimento que tivemos é que ele acredita no trabalho como possibilidade de ter um futuro, mas para ele o trabalho parecer ser algo importante e distante.

A aluna E.D.S. cita a droga, a violência e o desemprego como os maiores problemas que o jovem enfrenta na região. Ao contrário dos alunos anteriores tem perspectiva de futuro, apesar de sentir que o Estado deixa a periferia abandonada à sua própria sorte.

\subsection{Falam os atores educativos da escola privada}

O convite para a entrevista junto aos professores e direção da escola privada foi realizado de forma genérica, levando-se em conta a disponibilidade de cada um em colaborar com o trabalho, entre os diversos que se predispuseram a falar foram escolhidos 
três, considerando-se o envolvimento com o tema, a experiência de magistério, tanto na rede pública como na rede privada. As entrevistas foram realizadas na coordenadoria, inclusive tendo a coordenadora também se prestado a falar. Da mesma forma o convite aos alunos foi realizado de forma genérica e se escolheu quatro entre os diversos que se apresentaram, levando-se em conta a disponibilidade de tempo. Os entrevistados são assim identificados:

\section{a) Coordenadora Pedagógica M.R.M.M.}

Ela é licenciada em Artes pela Universidade São Judas Tadeu e com especialização (pós-graduação lato sensu) na área de educação em Psicopedagogia, tem quinze anos de magistério e dez anos de coordenação.

\section{b) Professores}

1) E. I, Licenciada em Letras, pela Universidade de São Paulo, leciona apenas na escola privada, com vinte e seis anos de magistério, tendo iniciado no período do regime militar;

2) J.A.F., licenciada em Letras, pela Faculdade Paulistana, estando atualmente cursando complementação pedagógica, leciona nas duas redes (sendo professora efetiva na rede pública estadual), com sete anos de magistério, iniciou dentro do período democrático;

3) S. R., licenciada em História, pela UNICASTELO, com vinte e dois anos de magistério, englobando período inicial como professora das séries iniciais do Ensino Fundamental (popularmente: professora primária), leciona nas duas redes, tendo iniciado a carreira no período autoritário.

\section{c) Alunos}

1) B.S.D.M, aluna cursando a 3a série do ensino médio, com 16 anos de idade;

2) L.L. aluno cursando a 3a série do ensino médio, com 17 anos de idade; 
3) G. S., aluna, cursando a 2a série do ensino médio, com 17 anos de idade; e

4) T.F., aluno cursando a 3a série do ensino médio, com 18 anos de idade.

Iniciamos o processo de seleção de dados, também com a Coordenadora Pedagógica.

\section{Aspectos da fala de M.R.M.M. coordenadora pedagógica da escola particular}

Parece ficar evidente que problemas da escola particular são diferentes dos problemas da escola pública, para ela a rotina é simples e cansativa, e os professores, estes sim, estão sempre reclamando que determinados alunos falam muito, pedindo a presença dos pais, fazendo ocorrências, pois existe uma ficha de ocorrência disciplinar, mas sempre evitando fazer relatórios, no qual a coordenação baseia-se para convocar pais e tomar medidas disciplinares que, conforme relatório, pareçam necessárias.

As medidas são tomadas a partir da identificação dos fatos geradores das dificuldades dos alunos, que ocorre nos primeiros dias de aulas, recomendando-se aos professores que conheçam o aluno. Para a coordenação também é fundamental que se respeite a saúde e os direitos da criança e do adolescente, elementos essenciais para uma boa educação e também fica claro como se trabalham as dificuldades dos alunos: "quando percebemos que o aluno vai mal, normalmente encaminhamos a fonoaudiólogo, médicos oftalmologistas, psicólogos, psicopedagogos, uma vez que sempre aparece algum caso de hiperatividade, dislexia, discálculia, etc.”. (M.R.M.M. coordenadora da escola privada).

A desestrutura familiar também atinge e prejudica o aluno da escola privada. Segundo a coordenadora às vezes aparece alguma criança ou adolescente com um quadro de agressividade e que normalmente o problema é familiar, quase sempre são filhos de pais separados, ou mães solteiras. A solução parece fácil "exigimos dos pais que eles passem os filhos por psicólogos". (M.R.M.M. coordenadora da escola privada).

A orientação é feita em relação aos pais e aos alunos e percebe-se também que é mais fácil trabalhar com os pais dos alunos da rede privada, o que se evidencia na exigência de 
retorno dos pais, quando são realizados os encaminhamentos a especialistas. A orientação aos pais ocorre quando se mostra a eles o ECA e no ensinamento de como proceder junto ao Ministério Público, caso eles não tenham recursos para passar a criança pelos especialistas e a conclusão é baseada em fatos da realidade, pois a coordenadora diz saber que a maioria paga a escola com muita dificuldade e que realmente realizam sacrifícios para manter os filhos em escola particular.

A constatação de que é muito difícil ser cidadão na periferia é seguida de orientação de onde e como encontrar ajuda jurídica, para fazer valer o direito do aluno. Afirma que é muito difícil ser cidadão na periferia, o desrespeito para com todos é grande, "mas procuramos orientar o aluno da melhor maneira possível para que ele faça valer seus direitos". (M.R.M.M.coordenadora da escola particular).

Chama atenção a afirmação “o Ministério Público tem outras preocupações, não se preocupa muito com o bem estar do povo e (...), prefere as luzes da ribalta, seus membros são loucos para aparecer na televisão em questões de pouco ou nenhum interesse popular". (M.R.M.M. coordenadora da escola privada). Existem instituições que são peças importantes para a cidadania e a prática democrática, que eram invisíveis e agora são notadas e criticadas de forma explícita, não se fica mais na critica vaga contra o governo. Isto é bom porque percebese que "acabam funcionando um pouco, ninguém gosta de ser pressionado por pessoa "chata", que conhece seus direitos" (M.R.M.M. coordenadora da escola privada).

A droga é o maior problema e o que exige maior atenção. Em relação ao meio é preciso atenção permanente. Sempre ocorre denúncia de que traficantes estão nas proximidades e a coordenação aciona sempre a polícia, pois a mantenedora paga para ter a presença da polícia, "Como fazem os supermercados e outras empresas da região, que tem permanentemente viaturas policiais estacionadas em suas portas" (M.R.M.M. coordenadora da escola privada). 
Fica evidente que se paga por aquilo que é um direito: a proteção policial. Quem não pode pagar não tem direito à proteção, é a regra na periferia. É comum ver duas ou mais viaturas policiais estacionadas na porta de estabelecimentos comerciais como supermercados, indústrias, padarias, em suma, dos pequenos poderosos locais. A polícia na periferia é uma instituição estatal, mas cujos agentes oferecem e prestam serviços privados. “A nossa região é violenta, abandonada pelo Estado, que oferece as instituições, que não funcionam ou funcionam insatisfatoriamente. Aqui é preciso pagar por tudo, inclusive pela segurança" (M.R.M.M. coordenadora da escola privada).

Vale dizer que a Senhora coordenadora fez críticas também ao judiciário, reconhecendo inclusive que o cargo de juiz não deveria ser vitalício, mas admitindo que o Judiciário é um poder de Estado e contestado um ou não tem quer ser acionado pelo cidadão.

\section{Principais colocações da fala da Professora E. I. da escola particular}

Ela constata a existência da legislação em favor da cidadania, mas que não se utiliza ou trabalha. "O Estado, teoricamente, mostra maior interesse em preparar o cidadão: as leis estão aí, disponíveis e prontas para serem trabalhadas..., o problema é que não se trabalha". (E.I. professora da escola particular).

Como educadora demonstra sintonia com o processo educacional ao afirmar que o aluno de ontem recebia informação rotulada, em todas as disciplinas; era avaliado com rigor e as avaliações visavam a conteúdos extensos que, em tese, dariam a dimensão do seu intelecto.

Classifica o processo educacional de alguns anos atrás como uma "Educação cobradora, quanto mais enérgica, mais preparava para a vida. Poucos tinham acesso e os que tinham acesso temiam a escola, principalmente a escola pública" (E.I. professora da escola particular), admitindo que o aluno do ESTADO era olhado com respeito, pois se diferenciava dos outros, intelectualmente. 
Para ela, o aluno de hoje, teoricamente tem uma escola com as portas abertas à sua espera, com planejamentos escolares visando à sua integração ao meio, através de projetos interdisciplinares; as informações que recebe devem ser baseadas no aspecto qualitativo; as avaliações devem observar suas competências em diversos momentos da aprendizagem e não somente através de uma prova escrita ou exame. "Digo teoricamente, porque na prática, a maioria das escolas apesar das mudanças, dos avanços, ainda pratica a educação à moda antiga: privilégio da quantidade de informações; avaliação unilateral, aulas com conteúdos isolados sem a preocupação de trazer para o momento da aula, situações da vida do aluno". (E.I. professora da escola particular).

Após discorrer sobre o processo educacional, apresenta dúvida quanto à preparação do professor que vai trabalhar a questão da cidadania (coisa que o coordenador da escola pública já havia ventilado). Em seu entendimento não basta ter uma grade contemplada por filosofia e sociologia, ao lado de História e Geografia e outras disciplinas básicas e afins, bem como um planejamento, para ela é preciso saber se o professor habilitado que ministra a disciplina sabe como trabalhar a disciplina.

Em seguida discorre sobre cidadania "O que caracteriza o cidadão é a sua participação na vida social, nas decisões que dizem respeito ao desenvolvimento da comunidade e do país. É preciso que todo cidadão tenha seus direitos respeitados e seja cumpridor dos seus deveres".(E.I. professora da escola particular).

Fala que o Estado oferece as ferramentas que são a escola e o professor. Entende que é participando que se aprende a participar e, observando por este ângulo, acha que as propostas de hoje são interessantes, bem intencionadas, porém pouco praticadas e quando praticadas deixam a desejar quanto ao estímulo do exercício consciente da cidadania, "mas isto é uma questão de gestão e administração escolar, consciência e preparação do professor" (E.I. professora da escola particular). 
Conhece as carências da periferia e reconhece que é difícil exercer a cidadania na periferia. Ela afirma que a escola deve ser vista como o fator que faz a diferença e que modifica a sociedade para melhor; isso sempre e a qualquer tempo. E, segundo ela, ocorre um processo de paralisia em regiões menos favorecidas e mais distantes, o que faz com que muitos tenham de conviver por muito tempo, ainda, com situações humilhantes, indignas. Reconhece a tendência desigual e injusta, ao perceber a inexistência de escolas públicas que visem à profissionalização, em quantidade que atendam a demanda da periferia. Para ela, a cultura escolar no bairro limita-se às escolas e uma ou outra biblioteca pouco recheada de livros; há pouca divulgação das atividades culturais na redondeza. Nos demais segmentos, há falhas sérias: faltam centros de convivência para crianças, jovens e adultos; a saúde é um outro problema: fila de espera; quem necessita de tratamento mais especializado normalmente passa semanas esperando por uma consulta, não há como acomodar todos aqueles que carecem de atendimento.

Reconhece a existência de um quadro de violência e a ausência do Estado. Para ela a violência é uma realidade inegável, inclusive nas escolas públicas que se equipam como verdadeiros presídios e têm que abrigar no seu interior o produto do meio, que é o aluno violento ou alheio a qualquer responsabilidade social. E concluiu que as ações do Estado são lentas e muitas vezes ineficazes; muita teoria e pouca prática. "Os trabalhos mais eficientes são os desenvolvidos por entidades organizadas pela própria comunidade, ou instituições como igrejas, por exemplo". (Prof. E. I. professora da escola particular).

Acredita que há na escola pública, muitos projetos preocupados com a "inclusão" do aluno na vida em comunidade; projetos que visam a um aproveitamento do mundo conhecido pelo aluno. Não raro observa que projetos excelentes escoam pelo ralo, pois não têm sequiência dentro da própria escola - habilidades artísticas, artesanais, de liderança são colocadas de lado por falta de interesse dos gestores escolares ou dos docentes ligados à 
instituição - mas o Estado leva a culpa. Para ela as tentativas de trabalhar a preparação para a cidadania consciente são e serão sempre válidas, pois não é possível conviver com a idéia de adultos irresponsáveis, sem iniciativa e com baixa auto-estima. Na escola particular, vê que há mais preocupação com o domínio do conhecimento das matérias escolares - o preparo para o mundo competitivo.

"Isso não quer dizer que a questão cidadania fique de lado dentro de seus contextos; o procedimento é outro; via de regra fica embutida nas pesquisas escolares, nas discussões em sala de aula; nos procedimentos administrativos; muitas escolas trazem nos seus planos projetos grandes visando exclusivamente à consciência de valores: solidariedade, preservação do meio-ambiente; reciclagem, preservação da fauna, segurança, primeiros socorros". (Prof. E. I. professora da escola particular).

No entanto, para ela, na periferia, a família que busca uma escola particular, geralmente quer garantias de excelência no conhecimento adquirido pelo aluno e quer retornos concretos em termos de conteúdo e a escola vai perpetuando o modelo tradicional e às vezes não preparando o aluno adequadamente para a participação na organização da vida política do país.

Lembra que a escola deve ser vista como o fator que faz a diferença e que modifica a sociedade para melhor; isso sempre, a qualquer tempo e é necessário estar sintonizado com o cotidiano, trazer a discussão das questões de impacto e repercussão social postas nos meios de comunicação para a sala de aula. Discutir as propostas no parlamento, as propostas do Executivo, o como o Judiciário e o Ministério Público encaram as questões que são vitais para o cidadão e que passam por eles e, sobretudo, insistir no conceito de que o Estado democrático tem que respeitar a minoria, mas tem que refletir a vontade da maioria e ser aquilo que a sociedade quiser que ele seja, que o Estado não é um ente ou um ser que decide por si só o que quer ser e como deve ser a sociedade. Finalmente, lamenta, 
“que a lentidão que observamos nos grandes centros, passa a ser um processo de paralisia em regiões menos favorecidas e mais distantes: muitos terão de conviver por muito tempo, ainda, com situações humilhantes, indignas, protagonizadas pela falta de sintonia entre o sentimento do povo e os poderes do Estado" (Prof. E. I. professora da escola particular).

\section{Dados da fala da Professora J.A.F (escola particular)}

Fica evidente que ela percebe que é possível haver um bom trabalho em torno da cidadania na escola pública, onde a educação para a cidadania é vista dentro do conceito de objetivo geral, desde projetos propostos pelo próprio Governo, como escola da família, até os oferecidos em oficinas, como o projeto água fonte da vida, nos quais os professores participam de encontros e ou palestras e devem propagar o conteúdo na escola em que lecionam. Fala que existem também projetos propostos pelo próprio corpo docente, nos quais eles são livres para criar e para por em prática. Para ela a existência de projeto próprio da escola e seqüência de trabalho na escola particular, é o que faz a grande diferença em relação à escola pública, que ou recebe projeto formulado pela Secretaria da Educação e se por acaso formula projeto, não dá a mesma seqüência. Acredita também que existe o problema de preparação do professor quando diz que "não basta você ter filosofia na grade curricular e um planejamento que exige que seja dado o Sócrates, por exemplo, é importante entender o Sócrates na formação da cidadania, e aí depende de como o professor vai ministrar Sócrates, e isto na maioria das vezes escapa do controle da coordenação”. A preparação do professor para ela é uma questão grave na escola pública, mas existe também em menor proporção na escola particular da periferia.

Sob o ponto de vista dos direitos, ela vê que a questão da periferia é intranqüila, que o indivíduo tem consciência de sua "condição desigual" mas acha "natural" viver assim, ou seja, a disposição para a mudança é adiada ou esquecida, pois o próprio indivíduo ainda considera o Estado o responsável pela sua condição e fica esperando um governo salvador 
e a sua consciência cidadã fica relegada a um segundo plano e a sua baixa auto-estima o leva a aceitar a sua inferiorização.

"Sendo assim, passa a ser "normal" andar em coletivos superlotados e pagar caro pela passagem; ter o veículo danificado nos buracos das avenidas mal conservadas, não freqüentar as ruas devido ao risco de assaltos, aceitar uma escola desprovida de equipamentos ou com alto índice de faltas dos professores; para a periferia conviver com o descaso não é novidade na saúde, segurança pública, lazer, moradia, educação" Professora

\section{J.A.F (escola particular)}

Ela pensa que educar para a cidadania exige um esforço conjunto que deve incluir o corpo escolar, a família e a sociedade. O fator família é um entrave, pois segundo ela, vivemos momentos de desagregação familiar "muitos alunos não vivem com o pai e a mãe; convivem em dois ambientes e são espectadores de discussões, agressões, isso quando não são os próprios alvos dos incidentes”.(Professora J.A.F escola particular)

Ainda segundo ela, a escola aliada à comunidade seria o primeiro passo para a educação, a conscientização e o exercício da cidadania na periferia.

Para ela, a questão dos direitos sociais vai mal em todos os segmentos, as pessoas em sua maioria não sabem quais são realmente seus direitos e, portanto não os exigem. Admite que "melhorou um pouco os conhecimentos dos direitos do consumidor, a partir do Código do Consumidor e do Procon, mas ainda é muito pouco, porque a justiça é muito lenta e a impunidade acaba sendo a regra" (Professora J.A.F escola particular).

Apesar das dificuldades acredita no processo educacional e que "cada um em sua área busca levar o aluno a entender a praticidade do que ensina em seu cotidiano, levá-lo a uma visão crítica do universo em que vive, o que certamente vai levar a uma educação que construa realmente sua cidadania”. (Professora J.A.F escola particular).

\section{Parte do que disse a Professora S.R. (escola particular)}


A professora conhece as duas redes e admite que ambas trabalham a cidadania, mas com enfoques diferentes. Trabalha na escola particular e na escola publica e seu trabalho está voltado para conscientizar o aluno de maneira que ele possa contribuir de modo positivo dentro desta nova realidade que hoje vivemos. Segundo ela, na escola publica o programa "A escola da Família", tem dado oportunidade para a comunidade e ate mesmo dos jovens que não estudam a participar das atividades voltadas para o lazer e também para o aprendizado de algumas profissões como pedreiro, diversos tipos de artesanato, entre outros e acredita que isto tem dado resultado, "isto é cidadania participativa" (Professora S.R. da escola particular).

A escola particular, ainda conforme seu depoimento, possibilita trabalhar mais a questão da formação acadêmica, o histórico, origem e evolução do direito e definição dos direitos, de forma que os alunos tenham uma visão que possa contribuir de forma positiva para o exercício da cidadania. Admite que são realidades diferentes, embora tenha também alguns alunos com famílias desestruturadas, mas que o normal é que ele tenha estrutura familiar e perspectiva de futuro.

"Na escola pública o universo é outro, mas se trabalha a cidadania atendendo outras necessidades. $\mathrm{O}$ aluno da rede particular você o prepara para o futuro e o da rede publica precisa de urn atendimento imediato, para questões imediatas e você faz o que e possível fazer, o que acontece é que muitos professores e mesmo diretores (gestores) não estão preparados, não conseguem fazer a sua parte, mas eu entendo que a ação do Estado é positiva.” ( Professora S.R. da escola particular).

A professora admite que as realidades de ensino nas duas redes são diferentes. Acha ainda que o Estado funciona na periferia de acordo com o ritmo de compreensão que o cidadão faz do seu próprio direito e que as carências da periferia são resultados do insuficiente entendimento do cidadão do que seja seu direito. Acredita também que os 
professores não estão preparados para realmente ensinar para o aluno como se constrói a cidadania.

Coloca ainda que do ponto de vista político a democracia possibilita articulação, organização, cobrança, o que em longo prazo pode ter evolução e do ponto de vista social, com o fim da repressão todos os problemas apareceram. Eles já estavam ai, mas havia a truculência do Estado e as pessoas não percebiam. Admite que o Estado talvez ainda seja truculento na periferia, mas que pode ser denunciado e é possível lutar contra esta truculência e com o tempo a sociedade poderá controlar o Estado, as perspectivas hoje são outras. Avalia o que o pessoal reclama é do aparente excesso de direitos sem deveres de minorias, reclamam da indisciplina dos alunos, etc. Reconhece que o mundo é outro, as coisas mudaram, a censura ditatorial com o tempo está sendo substituída pela do bom senso, e que não se pode ficar clamando por censura dos órgãos de comunicação; e que enquanto as coisas não se assentam vão parecer que estão bagunçadas, mas que talvez seja necessário mais que uma geração para as coisas se acertarem.

Para ela, o governo faz o que acha correto, conforme a leitura que ele faz dos problemas da periferia e acredita que ele também em sua representação admite que tem alguma deficiência, acha que ele confunde a pobreza com deficiência o que na prática é o reconhecimento do morador da periferia como um subcidadão. Ilustra como exemplo, que no entendimento do governo a polícia não pode ser educada ou agir educadamente na periferia, senão ela acabará sendo vitima da violência deste morador; assim, o governo não vê a polícia como violenta e desrespeitosa e sim como enérgica. Portanto, é com este tipo de ótica que o poder público procura desenvolver as ações para a cidadania e é claro que não vão de encontro às necessidades reais do cidadão pobre. Assim, para a professora, "cabe a nós educadores, conscientizar o cidadão de que ele é igual sim e mostrar aos governantes que pobreza não e deficiência, que o cidadão pobre merece o mesmo respeito; que a energia da 
policia é violência mesmo" (Professora S.R. da escola particular). Conclui seu raciocínio dizendo que só a cobrança de forma organizada vai fazer o governo ter uma representação adequada de cidadania, com igualdade entre todos. Enquanto isto o governo acha que esta fazendo sua parte e que os projetos e investimentos que faz atende as necessidades do povo.

\subsection{Síntese dos depoimentos dos professores da escola particular}

O que aparentemente é uma questão de gestão, tal como foi visto nos tópicos da fala da coordenadora (escola particular) "que se respeite a saúde e os direitos da criança e do adolescente, elementos essenciais para uma boa educação" ou ainda na colocação "quando o aluno vai mal, normalmente encaminhamos a fonoaudiólogo, médico oftalmologista, psicólogo, psicopedagogo, etc. uma vez que sempre aparece algum caso de hiperatividade, dislexia, discálculia, etc.", ou mesmo no que parece ser semelhante "Ás vezes aparece alguma criança ou adolescente com um quadro de agressividade, normalmente o problema é familiar, quase sempre são filhos de pais separados, exigimos dos pais que eles passem por psicólogos" na realidade não é gestão é um problema de conscientização. O coordenador da escola publica falou em buscar os pais em casa e aqui a coordenadora fala em exigir retorno dos pais, mesmo na questão de pais separados, isto demonstra que embora oriundos do mesmo meio a natureza dos membros das comunidades é diferente embora possam ter o mesmo nível econômico financeiro. $\mathrm{Na}$ escola pública a exigência de passar os filhos por especialistas, para os pais que nem querem comparecer na escola fica muito difícil.

Parece ter ficado evidente nas falas dos professores da escola particular, que o quadro social da periferia é negativo, reconhecem a carência da região, o tratamento desigual, conforme disse a Professora E.I. (escola particular) "um processo de paralisia em regiões menos favorecidas e mais distantes: muitos terão de conviver por muito tempo, ainda, com 
situações humilhantes, indignas" e mais adiante reconhece "a tendência da sociedade desigual e injusta". Assim demonstram um contexto dentro do qual existe desestruturação familiar e no qual, segundo a coordenadora (M.R.M.M), a droga é o principal problema "sempre temos denúncia de que traficantes estão nas proximidades, sempre acontece de termos um ou outro caso de aluno envolvido com drogas, os problemas maiores estão lá fora".

Acreditam de forma geral que a legislação favorece o trabalho de educação voltada para a construção da cidadania, mas que o Estado parece não ter encontrado o caminho para consolidar esta educação e colocam em dúvida se existe ou não interesse imediato de que os alunos aprendam nesse momento, até porque as demandas sociais iriam sufocar o Estado, portanto é melhor a cidadania ir sendo exercitada aos poucos. Assim pode não haver um interesse de que os alunos aprendam realmente a fazer valer a Lei, sobretudo através do recurso judicial, conforme explica a professora S.R. (escola particular) "logo, é interessante para o governo, ensinar o aluno que em sendo um direito o cidadão pode ele exigi-lo através do judiciário?" Ou ainda conforme fala mais adiante "Eu poderia falar aqui em defensoria pública, delegacia especializada para atender o cidadão em suas relações cotidianas, em que a polícia é necessária para fazer valer o direito do cidadão". Continuou sua fala, citando o exemplo, de se fazer uma queixa de propaganda enganosa e a polícia ir até o local, ou quando ocorre caso típico de bares que são pontos de encontros de marginais à noite que é a base de onde eles operam - saem para roubar nas imediações e voltam para beber e cantar ou "ouvir música", bem alta, bem barulhenta e durante toda a madrugada (perturbação do sossego público), achando que neste caso, ou ao se denunciar uma transgressão no trânsito e outras pequenas coisas deste tipo, a polícia deveria cumprir o seu papel apurando os fatos, "que hoje você denuncia e a policia acha engraçado, dá risada e diz que não pode fazer nada" - a ação correta acabaria com a impunidade - começaria com coisas pequenas e chegaria nas 
maiores, a lei seria respeitada e por extensão os direitos dos cidadãos, etc.” (Professora S.R. escola particular).

Existe a consciência de que a impunidade é a regra e não só na periferia, mas sim na sociedade como um todo, o que vai de encontro a um sentimento comum do cidadão brasileiro.

Também acabam questionando a formação dos professores que possam ministrar conhecimentos específicos de formação de cidadania, conforme a Professora J.A.F. (escola particular) "é importante entender o Sócrates na formação da cidadania, e aí depende de como o professor vai ministrar Sócrates, e isto na maioria das vezes escapa do controle da coordenação e aí estaremos talando também em preparação do professor" e admitem a diferença dos problemas entre a comunidade escolar da escola pública e da escola privada.

A preparação do professor é um sentimento comum dos professores da escola privada e da escola pública, deixando claro também que o Estado tenta fazer sua parte, oferecendo ferramentas, que não estão sendo utilizadas corretamente por administradores escolares e por falta de articulação entre os diversos organismos públicos, como por exemplo, Ministério Público e Escola e ai sim acham que o Estado se omite, por não realizar esta articulação.

Os problemas são diferentes, mas quando demonstram semelhanças, os tratamentos parecem ser diferenciados. A rede privada conhece o aluno e os pais, que parecem mais interessados que os pais da escola pública (aqui parece evidente, pois mesmo tendo uma faixa de renda semelhante, um pai esforça-se para pagar uma escola particular e outro não, parece ser realmente uma questão de consciência).

\subsection{A educação para a cidadania na visão dos alunos da escola particular}

A fala da aluna B.S.D.M (escola particular) demonstra segurança ao definir cidadania 
e conceituar os direitos, expressando que toda pessoa deve cumprir seus deveres para poder exigir seus direitos, indicando como conjunto de direito à moradia, à educação, à saúde e a liberdade de opção por qualquer partido político, liberdade de expressão, concluindo que os direitos são sociais, civis e políticos.

A aluna acredita que as pessoas desconhecem seus direitos e por isto não correm atrás. Isto corrobora depoimento dos professores que disseram que academicamente é possível preparar melhor os alunos da rede privada. A partir daí a percepção do que seja a realidade na periferia demonstra ser uma só "você acaba sendo tratado igual aos outros, como uma pessoa sem consciência de nada, como se não fosse uma cidadã”. (Aluna B.S.D.M escola particular).

Acha também que o indivíduo oriundo de uma classe mais alta tem noção e por isso exige do governo, mas os de classes mais baixas não têm noção, não conhecem e acredita que na escola pública, pela experiência de amigos que a freqüentam, é mais difícil ainda e que fica mais complicado ter uma formação para a cidadania. Ela afirma que teve disciplinas dirigidas para a construção da cidadania e que teve a oportunidade de conhecer as leis e também os seus direitos e deveres. Finalizou sua entrevista dizendo que talvez o governo não queira que os cidadãos conheçam realmente seus direitos para não ser cobrado. "O governo fala muito em apoio e eu acho que se tem é muito fraco. Talvez o governo não queira que nós conheçamos nossos direitos p'ra gente não cobrar dele. Entendeu?” (Aluna B.S.D.M escola particular). Parece ser evidente que esta fala reproduz os sentimentos demonstrados pelos professores, o que parece ser natural no contexto da educação e que certamente nos faz refletir sobre o papel ou a importância do professor na questão crucial da preparação para a cidadania e, sobretudo, a questão da preparação do professor.

Vale ressaltar que o sentimento de que a cidadania fica no papel e que a periferia é 
discriminada, parece ser regra geral na periferia "Eu acredito que na periferia as condições são mais precárias, em um lugar mais rico deve funcionar, eu acho que é uma discriminação econômica. (Aluna B.S.D.M escola particular).

\section{Manifestação do Aluno T.F. (escola particular)}

No depoimento do aluno fica perceptível a ausência da ação do Estado ou do poder do Estado que não consegue controlar o crime organizado, porque ele expressa claramente que a cidadania tem mecanismos que faz com que o indivíduo cumpra com os direitos e deveres perante a sociedade e que a escola propícia a base de conhecimentos para que se seja um bom cidadão, ou seja, mostra o que é cidadania e dentro dessas noções ele mostra também quando o Estado é ausente como ação efetiva, não conseguindo se impor e controlar os marginais, deixando o povo à mercê dos bandidos. "Todo mundo sabe que o Estado é o poder, só que na periferia ocorre poderes alheios também, exemplo de facções" 22 . Continuando em seu raciocínio afirma que não adianta o cidadão pronunciar-se, nunca é ouvido e que o cidadão tem liberdade de expressão, só que essa liberdade de expressão desenvolvida em torno da democracia nunca é ouvida, bem como a democracia não é exercida, o que é um desrespeito ao cidadão.

Faz veemente e contundente crítica aos poderes instituídos "acompanhar mais de perto para ver se as leis estão sendo seguidas, cuidar melhor para que não se soltem tantos criminosos, como esse jornalista que matou a namorada, porque se um pode matar e ficar solto, então todo mundo pode matar e acho que é por isso que tem essa história de matamata todo dia na televisão; ver como está o ensino, se ele está mesmo voltado para a cidadania, porque muitas vezes o que está no papel não se cumpre”. Aluno T.F. (escola particular).

$22 \mathrm{O}$ aluno esclareceu que as facções a que aludiu são as do crime organizado, que compõem o Primeiro Comando da Capital (PCC) (e isto seis meses antes dos ataques de maio de 2006), que de forma popular é visto como um polvo com muitos tentáculos que controla tudo na periferia. A partir do momento que começou a se divulgar o plebiscito do estatuto do desarmamento, diversos alunos pediam nossa opinião como professores e nos trouxeram a informação que o PCC estava pressionando os moradores dos locais mais pobres para que votassem contra o desarmamento. 
O depoimento do aluno demonstra revolta e também o desenvolvimento da consciência cidadã na periferia.

\section{L. (aluno da escola particular).}

Afirmou que teoricamente conhece a cidadania que se ensina na escola, mas acha que é muito difícil agir como cidadão porque ninguém respeita, entende que o Estado deveria ser mais rígido e ter mecanismos que obrigassem as pessoas a cumprir as leis. Acredita que é preciso ajudar a comunidade, não só por fazer algo por ela, mas sim por ser uma boa pessoa. Acredita que aqueles que exercem o poder constituem-se em um mau exemplo para a sociedade.

\section{G.S. (aluna da escola particular)}

A aluna chegou em São Paulo em 2005, veio da Bahia e acredita que as dificuldades que existem para o exercício da cidadania existem em função do tamanho da cidade, por isto o Estado não consegue suprir as necessidades ou atender as demandas sociais. Admite que aqui recebeu educação voltada para a cidadania. Às vezes não mostra clareza de raciocínio. O tamanho da cidade realmente a assusta.

\subsection{Síntese da opinião dos alunos da escola particular}

Algumas coisas ficam evidentes, que, por exemplo, os alunos da escola particular têm um melhor domínio dos conceitos acadêmicos de cidadania e a aluna B.S.D.M demonstra que "talvez o governo não queira que nós conheçamos nossos direitos para gente não cobrar dele. Entendeu?" e mostram sintonia com o que se veicula na grande imprensa, conforme disse L.L. "porque se tem exemplo é mais fácil as pessoas aprenderem, mas do jeito que vem ocorrendo hoje, com corrupção, fica meio difícil".

$\mathrm{Na}$ fala de todos encontrou-se o sentimento de omissão do governo e no dizer do aluno T.F. "Todo mundo sabe que o Estado é o poder, só que na periferia ocorre poderes alheios 
também, exemplo de facções", podemos sentir que ele colocou o dedo na ferida, que o governo não se impõe ao crime organizado, a periferia fica abandonada à sua própria sorte. E vai além em sua percepção "A liberdade de expressão foi criada em torno de uma democracia, só que essa democracia também não é cumprida". Portanto, parece que na periferia não se respeita nada. Os alunos demonstram consciência de cidadania e reconhecem dificuldades em exercê-la e tecem críticas pertinentes ao Estado, reconhecem, tal como os alunos da escola pública, que o caminho para a consciência e prática da democracia é a educação.

\subsection{A cidadania e a prática da democracia na visão dos membros da comunidade}

Os cidadãos da periferia demonstraram estar saturados com o que podemos chamar de poderes instituídos e com a verdadeira fraude que ocorre com seus direitos, evidentemente que não pode surpreender a revolta da sociedade contra a autoridade. Vejamos algumas falas, vamos começar pelo Senhor C.A.M., sobre o que é ser cidadão na periferia "É ser um qualquer, ser cidadão aqui em São Paulo é ser um qualquer, não tem cidadania, não existe mais cidadania, se você não tem emprego e não tem como sustentar seus filhos, não é um cidadão, só é cidadão na hora de votar. Certo?"

O amargo sabor de ser cidadão na periferia continua com a fala de que a podridão vem de cima, e que as mudanças tem começar de cima para baixo, começando pelos juízes, pela legislação que já é bem antiga, Código Penal que é de 1940, tudo isso, segundo ele está tudo parado há muito tempo, há mais de cinqüenta anos (50). Então, para ele é preciso começar tudo outra vez, mudar todos que estão no poder, tirar todos eles, "começar tudo outra vez", parece evidenciar que ele quer mudar também a forma de se chegar ao poder. “Começar um novo processo, porque não teve democracia até agora, começar um processo novo, com pessoas novas, reorganizar a sociedade para se ter democracia”. (C.A., membro 
da comunidade e pai de aluno)

Parece ser uma cansativa rotina a constatação de que a polícia é e sempre foi um problema para a periferia. Afirma que tem medo das duas policias, a civil e a militar, e que ambas são corruptas, mas que a civil é mais corrupta. E constata o Senhor C.A. de forma indignada que foi fazer queixa de que roubaram o seu carro e as autoridades policiais ficaram perguntando qual o seu nível de escolaridade e se ele tinha seguro do carro e quando ele disse que não, "nem perguntaram onde foi que eu fui roubado e como eram os bandidos que me assaltaram, eu tentava falar e eles nem tomavam conhecimento, me trataram que nem cachorro depois que eu disse que não tinha seguro". (C.A.M. pai de aluno e membro da comunidade)

Relata ainda o Senhor C.A. que seus filhos tem que ser colocados numa escola particular porque na da Prefeitura e do Estado os marginais estão no portão. Afirma ainda que polícia não tem nenhuma, "você não vê polícia, você só vê polícia na padaria, nas escolas você não vê nenhuma, só vê nas padarias, lanchonetes, fazendo segurança, bico...na escola não tem polícia, então é melhor ainda a particular".

Para ele o poder judiciário é o principal problema, solta bandidos, não pune, mesmo tendo a lei e conclui "Eu queria ser Juiz, ser marajá, ganhar vinte e quatro mil por mês...que legal heim, é o povo que paga...e você ainda ganha por fora e pouco importa se quem sofre é o povo"(C.A.M. Pai de aluno e morador da periferia).

Outro membro da comunidade radicaliza e diz que quem gera a violência na periferia é a própria polícia “os próprios policiais amedrontando as pessoas, sendo quem protege, estou falando de periferia mesmo, quem protege, na questão física das pessoas, são os próprios bandidos que mandam no local". (M.C.B., comerciante e membro da comunidade). Segundo ele é assim que ele vê e vive na farmácia na Cidade Tiradentes.

Ainda em seu depoimento ele diz ver várias injustiças, vê presos saindo na hora que 
quer, vê rebeliões o tempo todo na televisão e nada sendo feito. Acha que a justiça é morosa e leva o cidadão a desistir de procurá-la, e que tudo isto "é contra a democracia, tudo é contra a legalidade, tudo é contra a lei, parece que tudo é ao contrário".(M.C.B., comerciante e membro da comunidade).

Para o Senhor M.C.B a democracia não funciona e existe direito para uma pequena minoria. Entende que deve mudar-se tudo e que a mudança deve começar pelo judiciário, que os juízes não podem ter tanto poder do jeito que tem, porque só eles acabam tendo direitos e que usam em benefício próprio e contra a sociedade.

As entrevistas com os demais moradores seguem o mesmo tom, com acusações à polícia, o reconhecimento de que não existe igualdade de direitos, com acusações de discriminação do morador periferia, que é visto como sendo inferior, o que implica em reconhecimento de subcidadania e com acusações de uma pratica generalizada de corrupção por parte de todas as autoridades. O tom geral é de que o caminho para a mudança é o da educação.

Ressalte-se houve uma fala em que existe a referência explicita ao autoritarismo em nossa sociedade que para o entrevistado é fruto do processo histórico e a afirmação de que o Poder Legislativo vive em constante estado feérico e o Poder Judiciário emperrado e marcado como na "Ilha da Fantasia, pelo costume de chefete que cada patrício nosso possui, quando assume um cargo, não trabalha para o coletivo, mas como autoridade sentese dono da verdade absoluta, senhor da formalidade e tanto pior para a sociedade". (A. C. membro da comunidade).

Em seguida, o membro da comunidade pergunta se isto não é uma Ilha da Fantasia e indaga ainda em que mundo estão os senhores magistrados? Continua seu questionamento com a fala de que se é possível a democracia dentro deste estado de coisas? Em seguida faz referência ao caso que ganhou repercussão nacional do magistrado que expediu ordem de 
busca e apreensão de criança de 3 anos $^{23}$, pergunta em que mundo está este magistrado e a sociedade tolera, até quando? E arremata:

apenas para concluir a questão, circula nos meios jurídicos que os senhores magistrados não tem se dado ao luxo de ler os processos, parece que os processos são lidos, analisados e despachados pelos técnicos judiciários, pela assessoria dos senhores juízes, que eles apenas assinam os despachos. Pergunto, para que magistrados? Não seria melhor conselhos comunitários? (A. C. membro da comunidade).

Pelos sentimentos expostos fica claro que a população sabe quais são os problemas que enfrenta e quais são as origens dos problemas que enfrenta e, sobretudo que ela sabe qual caminho deverá ser trilhado para saná-los, o que ela ainda não sabe é como fazer para percorrer o caminho e por isto acredita que o caminho será trilhado na medida em que a educação oferecer ferramentas ao cidadão.

${ }^{23}$ Fato amplamente noticiado pela imprensa, na qual Magistrado na cidade de Serrana, região de Ribeirão Preto, expediu ordem de busca e apreensão de criança de 3 anos, por ter atirado pedra que acerto um carro que passava pelo local. A policia cumpriu o mandato, a criança e seu pai foram conduzido por força policial à presença do Juiz. 


\section{CIDADANIA, DEMOCRACIA, SOCIEDADES PERIFÉRICAS, SUBCIDADANIA E EDUCAÇÃO.}

\subsection{Definição e Dimensões de Cidadania}

O processo histórico-sociológico que levou ao surgimento de classes, à construção do Estado, da cidadania e da democracia, como fatores interligados, nasceu no mundo gregoromano e serviu de inspiração para a reflexão moderna que deu origem à Declaração Universal dos Direitos Humanos que foi assinada a em dezembro de 1948, constituindo-se no primeiro acordo internacional sobre os direitos da humanidade.

O conceito de cidadania, hoje, tem grande abrangência, uma vez que abarca princípios praticamente de todas as atividades fundamentais e necessárias à existência humana de forma digna. É uma exigência do Estado Democrático de Direito, sendo a ferramenta fundamental para reduzir as desigualdades sociais.

A Declaração Universal dos Direitos do Homem proclamou, então, quatro ordens de direitos individuais:

1. os direitos pessoais do indivíduo (direito à vida, à liberdade e a segurança);

2. os direitos do indivíduo em face das coletividades (direito à nacionalidade, direito de asilo, direito de livre circulação e de residência, direito de propriedade);

3. as liberdades públicas e os direitos públicos (liberdade de pensamento, de consciência e religião, de opinião e de expressão);

4. Os direitos econômicos e sociais (direito ao trabalho, à sindicalização, ao repouso, à educação, etc.).

Considerando tais princípios, o direito internacional, entendeu que a cidadania é ter o 
direito a uma nacionalidade, pois expressa a igualdade dos indivíduos perante a lei, a sua inserção em uma sociedade organizada, sendo qualidade do cidadão a detenção do poder de exercer o conjunto de direitos e liberdades políticas, socioeconômicos do seu país, estando sujeito a deveres que lhe são impostos. Relaciona-se, portanto, com a situação jurídica de uma pessoa em relação a um determinado Estado. Implica em reconhecer-se e ao mesmo tempo ser reconhecido como membro de uma comunidade.

Na perspectiva de Marshal (1967, p. 63-64) a cidadania incorpora três tipos de direitos: os civis, os políticos e os sociais.

O elemento civil é composto dos direitos necessários à liberdade individual: liberdade de ir e vir, liberdade de expressão, pensamento e fé, o direito à propriedade e o direito à justiça.

Por elemento político, para ele, se deve entender o direito dos indivíduos de participar do exercício do poder, como membros de uma instituição investida de autoridade política ou como eleitores de tais membros ou representantes. As instituições correspondentes são o parlamento e os conselhos do governo local.

E ainda segundo ele, o elemento social da cidadania, refere-se a tudo que vai do direito a um mínimo de bem-estar econômico e segurança ao direito de participar da herança social e levar a vida de um ser civilizado de acordo com os padrões que prevalecem na sociedade. As instituições mais ligadas com ele são os sistemas educacionais e de serviços sociais.

Foi na segunda metade do século XX que surgiram os direitos de terceira geração, que têm como titular não o indivíduo, mas os grupos humanos, como o povo, a nação, coletividades étnicas, minorias discriminadas e até o direito de autodeterminação dos povos.

Ressalte-se, então, a noção fundamental que encerra a questão da cidadania: o cidadão 
tem direitos e deveres e, assim, podemos concluir que a participação política, a responsabilidade pelo conjunto da coletividade, o cumprimento das normas de interesse público, por exemplo, são deveres; que a cidadania é histórica, desta forma varia no tempo, conforme o período histórico e o contexto vivido; que cabe sempre perguntar quem pode exercer plenamente a cidadania; que ela é sempre uma conquista do povo o que nos leva consequientemente ao conceito de que a ampliação dos direitos de cidadania depende da "capacidade política" dos cidadãos, da qualidade participativa desenvolvida; que as formas de participação decorrem do tipo de sociedade política em que se vive; e finalmente que a cidadania não se encerra nas suas dimensões da liberdade individual e participação política, mas inclui os direitos sociais e coletivos.

Para Bobbio $(1992)^{24}$, quando a burguesia chegou ao poder na França, através da Revolução Francesa ou Burguesa, foi estabelecida a igualdade formal de todos perante a lei e levanta daí a questão sobre os direitos humanos, formulando três teses centrais:

1. os direitos naturais são direitos históricos;

2. nascem no início da era moderna, juntamente com a concepção individualista da sociedade;

3. tornam-se uns dos principais indicadores do progresso histórico.

É com essas três teses que Bobbio aponta o caráter revolucionário do reconhecimento dos direitos naturais do homem e constata na Declaração dos Direitos do Homem e do cidadão de 1789 uma virada na história do gênero humano. Com base nessas três teses. Bobbio percebe que os direitos do homem são fins a serem perseguidos sempre, já que eles não foram ainda totalmente colocados em prática.

Para Mondaini $^{25}$ (2005) o problema fundamental relacionado aos direitos do homem e

\footnotetext{
${ }^{24}$ BOBIO, Norberto. A era dos direitos. Rio de Janeiro: Campus, 1992. "A herança da grande revolução". In: A era dos direitos, cit., p.113-30.

${ }^{25}$ MONDAINI, Marcos. O Socialismo Liberal de Norberto Bobbio - Especial para Gramsci e o Brasil -pagina da Internet, acesso: em 28 jan. 2006.Brasil -Textos/Marx\&Marxismo - Disponível em
} 
conseqüentemente à cidadania, na contemporaneidade, não é tanto o de justificá-los, mas sim de protegê-los - não se trata mais de uma questão filosófica (como o fora na Idade Moderna), mas sim política. O ponto nodal, em suma, é a realização concreta dos direitos humanos. - Se a polêmica acerca dos seus fundamentos foi definitivamente solucionada em 1948, com a Declaração Universal dos Direitos do Homem o debate sobre a sua efetivação ainda não o foi. Segundo Mondaini (2005) é inegável que a humanidade progrediu moralmente, ao passar de uma "era dos deveres" para uma "era dos direitos". Porém, não se pode encobrir que há uma diferença substancial entre "direito atual" (um direito reconhecido e protegido) e "direito potencial" e assim conclui que um direito, para ser atual, precisa transformar-se, de objeto de discussão de uma assembléia de especialistas, em objeto de decisão de um órgão legislativo dotado de poder de coerção.

\subsection{Idéia, evolução e dimensão de democracia.}

Em A Teoria da Democracia Revisitada de Giovani Sartori, (1994) ${ }^{26} \operatorname{logo}$ em seu início, nos lembra da importância de uma definição inteligível do conceito de democracia e também das dificuldades inerentes a esse desafio. Quando o autor busca seu significado etimológico, em suas “bases genuínas”, remontamos à Grécia antiga. A palavra democracia vem do grego: demos (povo) e kratia, de krátos (governo, poder, autoridade). Esclarece em seguida que para Aristóteles democracia é uma forma degenerada de república uma sociedade política ruim, "O Estado que os homens livres governam" (Aristóteles, 323 a.C.:120), o que excluía as mulheres e escravos.

Bresser-Pereira (2004) propõe um modelo histórico para classificar os regimes políticos, os tipos de administração e os correspondentes tipos de democracia. Ainda que não expresse diretamente uma visão substantiva de democracia, o modelo mais avançado, 
segundo o autor, se caracteriza por um elevado grau de inclusão da cidadania. Considerando a definição de democracia adotada por Bresser, segundo a qual (BresserPereira, 2004:30), não se pode falar em democracia no Estado liberal (caracterizado pela administração pública burocrática), quanto menos em sua forma anterior, o Estado absolutista (cuja administração era patrimonial). O Estado liberal-democrático (que manteve a forma de administração pública burocrática e representa a democracia de elites de Shumpeter, 1942) ${ }^{27}$, solapou o autoritarismo, entretanto observou a emergência da questão da justiça social. A resposta a essa questão e também ao problema da igualdade de oportunidades veio com o advento do Estado social-democrata (wefare states), cujo tipo correspondente de democracia é a de opinião pública (ou social/plural).

No entanto, a questão da eficiência econômica, cada vez mais imperativa, exigiu a transformação para o Estado republicano, que com o gerenciamento público e a democracia republicana (ou participativa), conseguiu responder às necessidades de melhor uso dos fundos públicos, aliada ao aumento de eficiência na promoção de serviços sociais e científicos.

É neste contexto que Bresser Pereira (2002) afirma que a expansão da democracia historicamente começa com o advento da revolução capitalista. Esta revolução, que levou ao aparecimento da idéia de lucro, criou nos grupos sociais uma nova forma de captura do excedente. Anteriormente, o excedente era capturado por meio de violência, o que levava a classe aristocrática a ter medo de quaisquer liberdades políticas que pudessem, de alguma forma, levar à expropriação de seus bens. A burguesia, no entanto, que surge como uma nova classe social na revolução capitalista, se apropria da noção de lucro como meio de captura do excedente, o que transfere os meios de captura para o mercado e o trabalho. Nesse contexto, sem medo de perder seus bens pela violência, a classe burguesa consegue

${ }^{27}$ SCHUMPETER . Capitalismo, Socialismo e Democracia. New York, Harper \& Brother: 1942 - Caps.21, 22 e 23. 
aceitar e assimilar a democracia e as liberdades. Paralelamente a esse processo, há o advento do estado de direito, a partir do qual o Estado passa a garantir os direitos de propriedade, cumprimento das leis e enquadramento legal das ações. Assim, segundo Bresser (2002), esses fatores históricos levaram ao advento da democracia que, ainda ao longo do século $\mathrm{XX}$, teve de debater contra diversos movimentos totalitaristas e fascistas para triunfar como o melhor sistema de governo.

Segundo Avritzer, "se, por um lado, esse debate foi resolvido em favor da desejabilidade da democracia como forma de governo, por outro lado a proposta que se tornou hegemônica no final das duas guerras mundiais implicou em uma restrição das formas de participação e soberania ampliadas em favor de um consenso em torno de um procedimento eleitoral para a formação de governos"28 (AVRITZER, 2004:1). Esse modelo, que se tornou hegemônico em diversos países no pós Segunda Guerra, pode ser analisado nas obras de autores como Schumpeter (1942), Dahl (1989), Bobbio (1986) e Przeworski (1999) ${ }^{29}$, entre outros.

Uma das características da visão hegemônica é a formulação minimalista ou procedimentalista de democracia. Esta formulação, que teve como base os trabalhos de Kelsen $(1955)^{30}$, vê democracia apenas como um procedimento metodológico, que, afirmam os autores, já é um ganho grande o suficiente em si mesmo. A democracia se dá já na medida em que se conseguem soluções para conflitos sem derramamento de sangue, como afirma Bobbio (1986).

A conquista da democracia não precisaria, portanto, ser substantiva, ou seja, conquistar valores e atingir resultados de justiça e igualdade. Ainda a partir de uma visão minimalista

\footnotetext{
${ }^{28}$ AVRITZER, L e SANTOS, Boaventura S. Introdução: para ampliar o cânone democrático. In: Reinvenção da Emancipação Social. Disponível em www.ces.fe.uc.pt. Acessado em 01/11/2006.

${ }^{29}$ PRZEWORSKI, STOKES E MANIN. Democracy, Accountability and Representation, Cambridge University, 1999.

${ }^{30}$ KELSEN, Hans. A Democracia. Tradução de Vera Barkow e outros, São Paulo: Martins Fontes, 1993. (Ensino Superior). Cf., Kelsen, op. cit., p. 205
} 
de democracia, autores, como Schumpeter (1942) e Pzeworski (1999), tratam da noção de democracia das elites, segundo a qual a democracia não precisa incluir a demos e deve ser exercida por um governo de qualificados. Por trás dessa formulação minimalista está uma visão da democracia, que a analisa como um método que permite o exercício da política. A partir dessa análise, o conceito normativo de democracia é esvaziado, chegando-se à conclusão, a partir de fatos, de que a democracia não se constitui dos valores ideais que a visão normativa coloca (da busca de valores de igualdade, justiça, promoção do bem comum e realização da vontade geral). Para Schumpeter (1942), por exemplo, a própria noção de bem comum não é real, na medida em que as sociedades são formadas por diversos grupos e classes com seus próprios interesses e incapazes, portanto, de ter um interesse comum e buscarem os mesmos objetivos. A visão hegemônica também trabalha com a percepção de que a representatividade se constitui na única solução possível em democracias de grande escala. Para Dahl $(1989)^{31}$, o potencial da participação é maior na medida em que se têm menores unidades democráticas.

A justificativa da representação se dá na questão da autorização que, por sua vez, se sustenta em dois pilares: o problema do consenso e à capacidade de formas de representação expressarem as distribuições das opiniões da sociedade (AVRITZER, 2004a). Para o autor, portanto, a concepção hegemônica liga o problema da representação exclusivamente ao problema das escalas, esquecendo de outras dimensões da representação: a autorização, a identidade (a representação não consegue abranger todas as identidades minoritárias) e a prestação de contas (já que a representação dificulta o processo de desagregação da prestação). E desse modo, apresenta-se mais um limite da concepção hegemônica: a dificuldade de representar agendas e identidades específicas.

\footnotetext{
${ }^{31}$ DAHL, Robert A. (1989), Um Prefácio à Teoria Democrática. Tradução de Ruy Jungmann. Rio de Janeiro, Zahar Editor Ltda. [1956].
} 
Os problemas da visão hegemônica acabaram por gerar más consequiências na qualidade da democracia, que vieram à tona, segundo Avritzer (2004), com o advento da chamada terceira onda de democratização. Para o autor, essa concepção de democracia trazia consigo uma degradação das práticas democráticas, o que coincidiu com uma grave crise de dupla patologia: a patologia da participação - com o aumento do abstencionismo e a patologia da representação - na medida em que os cidadãos se sentiam cada vez menos representados por quem elegeram. Nesse processo, o autor identifica três crises: uma crise de marco estrutural de explicação das possibilidades democráticas, uma crise homogeneizante sobre a forma de democracia e uma crise pela propensão de observar possibilidades de democracias diferentes em níveis locais com recuperação de tradições participativas dos diversos países.

Essas crises em relação à concepção hegemônica da democracia levam ao surgimento de teorias não-hegemônicas, que questionam seus principais problemas. A maioria dessas novas concepções, no entanto, não romperam com a resposta procedimental da democracia, vinculando o procedimento à forma de vida e entendendo a democracia como meio de aperfeiçoamento da convivência humana. Essa concepção, segundo a qual a democracia é uma gramática de organização da sociedade e da relação entre o estado e a sociedade, pode ser encontrada a obra de autores como Lefort ${ }^{32}$, Habermas (1995, 1987), entre outros (AVRITZER, 2004).

Essa nova concepção busca, primeiramente, um resgate da dimensão normativa da democracia, retomando o conceito de cidadania e de soberania popular - pautadas na idéia de participação dos cidadãos nos assuntos de interesse da coletividade.

Essa concepção não hegemônica reconhece a pluralidade humana e tenta trazê-la como resposta às forças homogeneizadoras de organização da sociedade. A partir disso,

\footnotetext{
${ }^{32}$ LEFORT, C. Pensando o Político. São Paulo: Paz e Terra, 1986.
} 
suspende-se a idéia do bem comum e busca-se uma nova institucionalidade da democracia que seja capaz de abarcar a pluralidade, principalmente baseada na garantia de direitos e liberdades políticas. Nesse contexto, o procedimentalismo passa a ser pensado como prática societária e não como método de constituição de governos, levando à abordagem dos elementos histórico-culturais dessa sociedade.

Para Habermas (1995), a esfera pública se constitui em local onde indivíduos podem problematizar em público suas condições de desigualdade na esfera privada, de forma a questionarem sua exclusão de arranjos políticos. O procedimentalismo, portanto, se funda na origem da pluralidade das formas de vida existentes nas sociedades contemporâneas. A questão da representação cultural e social também é levantada nessa concepção não hegemônica, na medida em que a consideração da pluralidade pressupõe o aumento da participação de atores na política. A percepção de que as formas tradicionais de representação na democracia não garantiam inserção de minorias leva à relativização da representatividade e a busca de novas soluções para a inclusão da diferença. É nesse contexto, portanto, que, segundo Avritzer (2004a), "a articulação entre democracia representativa e participativa parece mais promissora na defesa de interesses ou identidades subalternas".

Para Cohen ${ }^{33}$, o estabelecimento de condições para a discussão livre, igual e racional entre cidadãos tem três princípios básicos: a) princípio da inclusão deliberativa -todos os cidadãos têm direitos iguais; b) princípio do bem comum que diz sobre a possibilidade de um acordo público a respeito das prioridades sociais com vistas na promoção de maior justiça social; e c) princípio da participação e da garantia de direitos iguais da participação.

${ }^{33}$ COHEN, J. Procedimiento y Sustância em la Democracia Deliberativa. Metapolitica, México, v. 4, n. 14, abr-jun/2000. 
A idéia de democracia participativa também é apresentada por Bohman ${ }^{34}$ (2000), que defende a idéia de um processo pautado na cooperação, diálogo e comprometimento dos cidadãos para com os resultados de uma interlocução pública. Para ele, ainda, os acordos devem se basear na construção de interesse comum que, portanto, pressupõe integrar os partidos e o poder público para conduzir o processo de deliberação em espaços públicos como elo condutor na implementação das ações.

A importância da atuação do poder público no processo de democracia participativa também é apresentada por outros autores (COHEN, 2000), para o qual o poder público exerce um papel de estímulo no desenvolvimento de mecanismos que potencializem a ampliação de um associativismo civil atuante e vigoroso. O papel do Estado também é importante para garantir que os processos participativos conduzam não apenas para deliberações conjuntas, mas também para decisões que promovam o bem estar e a justiça. Nesse ponto, fica clara a necessidade de o estado institucionalizar as práticas que garantam a democracia participativa, para que ela se efetive e tenha legitimidade nas ações de deliberação pública. Todavia, para evitar que a democracia participativa se torne também apenas um procedimento decisório - como na visão minimalista de democracia - é preciso reforçar a necessidade de que as práticas de participação se dêem em ambientes de homens livres e iguais e, mais do que isso, que elas almejem sempre a justiça e o bem estar de toda a sociedade.

Vale ressaltar também que o diálogo entre a população e o Estado no desenvolvimento de políticas públicas possibilita que estas sejam feitas mais de acordo com as vontades e necessidades da sociedade, que tenham melhor qualidade e sejam mais efetivas na busca de seus resultados.

${ }^{34}$ BOHMAN, J. La Democracia Deliberativa y sus Críticos. Metapolitica, México, v. 4, n. 14, abr-jun/2000. 
Para a concepção não hegemônica de democracia, portanto, são importantes os seguintes elementos: que a democracia seja um processo de institucionalização de práticas e regras - baseadas no pluralismo e na equidade -, conduzido pelo Estado e cujas regras devem pautar um diálogo entre os atores da sociedade, livres e iguais, pela busca ultima do bem estar, da igualdade e da justiça.

\subsection{A formação das sociedades periféricas}

Jessé Souza (2003) coloca a discussão sobre a singularidade de uma enorme periferia de sociedades que se formam ou se transformam a partir da expansão planetária do capitalismo moderno, admitindo que ela não tem tido uma reflexão sociológica adequada; citando como exemplo a desproporção entre o estudo "das grandes culturas ou religiões mundiais" e os subcontinentes como a América Latina, que reconhece como sociedades complexas, constituídas pela própria dinâmica da expansão ocidental.

Utiliza o conceito de essencialismo cultural, que é a reprodução de quadros ou comparações, histórico-sociológicas, influenciado pela crença na tese weberiana de que a ética protestante é a parteira do mundo moderno (ocidental), uma vez que o utilitarismo e o cálculo racional, centrado no reconhecimento do trabalho humano como fonte de toda graça diante de Deus, origem da riqueza e medida da felicidade nesta vida e na outra, será a essência da constituição do espírito do capitalismo, o que faz que a sociedade moderna seja uma conseqüência do capitalismo.

A humanidade passou de uma sociedade tradicional, alicerçada na fé absurda e na tradição, para uma sociedade regida pela racionalidade, conforme demonstra a obra “Crítica da Modernidade”, de Touraine ${ }^{35}$, que tem como preocupação central a construção do grande projeto histórico da modernidade, destacando os seus aspectos positivos e

\footnotetext{
${ }^{35}$ TOURAINE, Alain. Crítica da modernidade. Trad. Elias Ferreira Edel.Petrópolis: Vozes, 1994.
} 
negativos. A importância desta análise reside no fato de que as sociedades ocidentais se organizam à luz da racionalidade.

Dentro do conceito teórico que supunha uma oposição entre tradição e modernidade, no qual este último era associado ao exemplo concreto da sociedade contemporânea americana, havia o pressuposto de que existiam etapas da sociologia tradicional da modernização, que as sociedades não ocidentais ou periféricas deveriam percorrer, ou estariam condenadas ao pré-modernismo. Só a repetição do processo das sociedades modernas centrais ocidentais poderia garantir o desenvolvimento, como fez o Japão.

Ainda segundo Souza (2003), a produção acadêmica no âmbito da sociologia brasileira, teve como paradigma dominante no século $\mathrm{XX}$, as noções complementares de personalismo, familismo e patrimonialismo, que fundamentam a idéia de uma sociedade pré-moderna. Assim as questões sociais típicas de países periféricos, tais como a desigualdade e a massiva marginalização de setores expressivos da população, bem como as dificuldades de consolidação de uma ordem democrática e de mercado competitiva e eficiente seriam explicáveis a partir dessa expansão pré-moderna de modelos familísticos, para todos os segmentos sociais. Desta forma, na fala de Souza (2003), o conceito dominante na sociologia e antropologia americanas da primeira metade do século $\mathrm{XX}$, permite partir-se de uma perspectiva em que a "cultura" é percebida como uma entidade homogênea, totalizante e auto-referida. Seria por conta dessa soberania do passado sobre o presente que nos confrontamos com solidariedade verticais baseadas no favor; subcidadania para a maior parte da população e abismo material e valorativo entre as classes e as raças que compõem nossa sociedade. Portanto, conclui Souza (2003), que as análises dentro desta lógica de um "culturalismo essencialista", reproduzem uma forma de subjetivismo sociológico em que as interações face a face e a intencionalidade dos sujeitos parecem se constituir, como no paradigma da relação favor/proteção, a referência última da 
análise.

Neste ponto é preciso recorrer à obra "A integração do negro na sociedade de

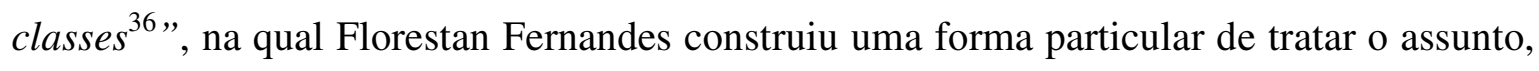
que vai permitir o desenvolvimento do conceito de subcidadania evidenciando a condição de marginalidade dos negros e dos mulatos situando a problemática na transição "da ordem social escravocrata e senhorial" para o "desenvolvimento posterior do capitalismo". A obra analisa os impasses vivenciados por negros e mulatos no esforço de inserção na nova ordem social, pontuada pelo "estilo de vida individualista e competitivo", construído pelo "novo regime de relações de produção". O problema racial, focalizado no prisma da dinâmica global de modernização da sociedade brasileira, evidente em São Paulo, como universo empírico privilegiado, realça-se uma situação paradigmática de exclusão social dos negros, por tratar-se do "primeiro centro urbano especialmente burguês", regido por mentalidade mercantil, iniciativa individual e liberalismo econômico, ingredientes que respaldavam o progresso encetado no período em questão, pós-lei áurea.

A partir do trabalho de Florestan Fernandes, dentro do período estudado de 1880 a 1960, no qual ele se propõe a compreender como o povo emerge na história brasileira, muitos autores, entre eles Jessé Souza, autor da obra a Construção Social da Subcidadania - para uma sociologia política da modernidade periférica - ampliam a reflexão de Florestan, para abranger também os demais estratos de despossuídos e os dependentes de forma geral e de qualquer cor, ao aceitar o princípio de que o único elemento que os diferenciava dos negros e mulatos era o adicional do racismo.

Ausentes a democratização efetiva e os direitos e deveres fundamentais dos indivíduos no plano concreto, a realidade instaurada alijou o negro do mercado de trabalho e da "ordem social competitiva", bem como os demais despossuídos, corroendo os fundamentos

${ }^{36}$ FERNANDES, Florestan. A integração do negro na sociedade de classes. São Paulo, Ática, 1978 (Vol. I e II). 
jurídicos e morais das relações contratuais, disputadíssimas em São Paulo pela competição desigual com o imigrante europeu.

Desde seus primeiros estudos sobre o folclore, passando pela análise dos índios e dos negros cujo coroamento ocorre em "A Revolução Burguesa no Brasil"37, obra na qual Florestan Fernandes discute a implantação e consolidação do capitalismo em nosso país, que segundo ele, vai ocorrer no pós-independência (1822), marcando o início do processo de modernidade brasileira, dentro daquilo que ele chamou de surto urbanizador e comercial que predominou em nossa sociedade ao longo do século XIX, o autor tematiza a sociedade brasileira na perspectiva da exclusão e da impossibilidade de se eliminarem os traços sociais do passado que se encontram mesclados às novas realidades, embaraçando a plena realização da ordem social competitiva.

Possivelmente convivem nessas inquietações elementos da sua própria biografia e que, talvez, possam iluminar a fidelidade do olhar de Florestan, construído na vivência das camadas populares. Ele percebe que as condições de inadaptação da população negra é comparável a dos dependentes rurais brancos, como compondo a "gentinha" ou a "ralé" nacional. A situação do dependente ou agregado despossuído branco ou de qualquer cor, era bastante comparável com a do negro escravo. Neste contexto a cor da pele é apenas um problema adicional, a essência do problema é a combinação de abandono e inadaptação, que ele bem demonstrou, atingindo ambos os grupos independentemente da cor. Muito das suas posições políticas prende-se a essa visão original da sociedade brasileira. No conjunto, a obra de Florestan Fernandes é indispensável para a compreensão da nossa modernidade e dos conceitos acerca da subcidadania.

Para ele, o Estado autoritário e modernizador, que se consolida a partir de 1930, não inicia o processo de modernização brasileira, apenas o coloca em outro patamar. A partir

\footnotetext{
${ }^{37}$ FERNANDES. Florestan. A Revolução Burguesa no Brasil. Ensaio de interpretação sociológica, Rio de Janeiro, Zahar, 1975.
} 
dele o processo de modernização passa a ser comandado pela industrialização. O Estado reformador de 1930 lança as bases para a transformação econômica, com ênfase nas indústrias de base - como siderurgia e petróleo - e pela construção capitalista da infraestrutura para um crescimento capitalista em larga escala. Ainda segundo ele alarga-se a ínfima base participativa e com bases democráticas a partir de 1946, de modo a incluir setores médios urbanos e os trabalhadores urbanos, ainda que sob bases corporativas, repressivas e desmobilizadoras, dentro de um modelo que vai perdurar até os anos 80 do século passado e foi neste período que foi possível institucionalizar-se as desigualdades, onde tanto negros como brancos sem qualificação adequada são desclassificados e marginalizados de forma permanente.

Conseqüentemente, ao definir subcidadania, recorrendo também a Florestan Fernandes, Souza (2003) fala de um tipo de modernização, com "anterioridade de práticas institucionais e sociais em relação às idéias e visões de mundo" e coloca o problema da "formação de um padrão especificamente periférico de cidadania e subcidadania" (p. 132133) e sublinha em nossa experiência periférica aquele déficit de "articulação" entre "práticas" e "idéias", déficit que significa duas ordens interligadas de consequiências: a) "ausência de perspectivas de longo prazo e ausência de adequada compreensão da profundidade e da abrangência dos novos comportamentos e papéis sociais que se desenvolviam" (Souza p. 132-33); e b) a "naturalização da desigualdade" por meio de certos ancoramentos institucionais. O autor radica nessa "esquematização" da modernidade brasileira sua tese da subcidadania. (Souza, 2003, p.207).

\subsection{Sociedade periférica e subcidadania.}

Fica evidente que a subcidadania tem uma raiz histórica e não restam dúvidas de que seu início ocorreu no período colonial. Parece estar ligada á própria formação histórica das 
camadas sociais mais baixas, que no dizer de Pedroso (1999, p. 18), eram rotuladas de marginais e intensamente perseguida pela polícia mesmo que não cometessem crime algum. Ser "marginal" constituía crime, classificavam-se dessa forma os vadios, os capoeiras, os escravos e os estrangeiros. A legislação penal do final do século XIX punia a ociosidade como crime. Era praticada a repressão de forma legítima aos desempregados e subempregados - os pobres -, ainda segundo Pedroso os legisladores utilizavam o termo "classes perigosas", como sinônimo de classes pobres, e isto significa dizer "que o fato de ser pobre o torna automaticamente perigoso à sociedade" (1999 p. 25).

Conforme o cientista político Jorge Zaverucha ${ }^{38}$, este enfoque deve-se a uma história institucional de um aparelho policial que tinha como postura ideológica, proteger o Estado e as elites contra o povo, mantendo um controle social de forma repressivo-violenta. Para garantir este controle, o Estado repressivo comandado explicitamente pelas elites, alocava o quanto de recursos fossem necessários para suas policias atuarem de forma truculenta e desumana contra qualquer movimento popular na busca da emancipação e da igualdade social. E ainda segundo ele, havia bastante recurso, visto que com a preponderância do Estado repressor hegemonicamente elitista sobre um Estado Democrático do Bem-Estar Social; eram prioritários o bem-estar das elites, e sua proteção, através da repressão policial sem nenhum compromisso com o bem-estar da maioria da população.

Com esta "abundância de recurso", por que se preocupar com eficiência policial? Com racionalidade? Ao menor ruído de insurreição ou de atentados individuais contra as pessoas das elites e seus patrimônios, o aparelho policial era acionado, mobilizando todos os recursos necessários para eliminar e massacrar os insurgentes e agressores da "Ordem Pública" ou “Ordem Social”.

\footnotetext{
${ }^{38}$ ZAVERUCHA, Jorge. Entrevista para a organização Delegados pela Cidadania _.htm Entrevistador: Delegados pela Cidadania, conforme matéria Postada em 10/12/2004) disponível no site http://www.delegadospelacidadania.org.br/index.php.
} 
Pinheiro (1991) ${ }^{39}$ afirma que não é por acaso que a pobreza no interior das classes populares é ainda hoje percebida com significado aproximado à repressão, ser pobre é ser reprimido. Para ele existem grupos que são desprovidos de significação, como possuidores de uma identidade coletiva conhecida e cita: trabalhadores, pobres sem atividades fixas, miseráveis, indigentes, mulheres, velhos, crianças, negros, homossexuais, loucos e criminosos.

Aqui é preciso recorrer à racionalidade Cartesiana que permite o cogito, o pensar em si mesmo, que é um instrumento que possibilita formulações teóricas sobre virtudes e concepções de dignidade, sobre a noção de superioridade e da boa vida que é resultante do próprio senso de dignidade e auto-estima do agente enquanto ser racional. Ter identidade é ser reconhecido, é viver com consciência de si mesmo e não simplesmente viver como um ser vegetativo, que apenas vive.

Para Charles Taylor (1991) a formação de identidade dá-se em um cenário de afinidades e oposições, dentro da perspectiva de avaliações fortes que possibilitam a discriminação entre o que é certo e errado, que torna possível repensar e demonstrar a vinculação entre uma hierarquia valorativa, que se traveste de universal e neutra, com produção de uma desigualdade social que tende a se naturalizar tanto no centro como na periferia do sistema.

Dentro deste contexto é que se abre espaço para se realizar o entendimento sobre a legitimação de hierarquias, segundo a capacidade diferencial de cada comportamento racional individual, buscando compreender Taylor ${ }^{40}$, que vincula a teoria do

\footnotetext{
${ }^{39}$ PINHEIRO, Paulo Sérgio. A estratégia das Ilusões (a revolução mundial e o Brasil-1922-1935). São Paulo: Companhia das Letras, 1993.

${ }^{40}$ TAYLOR, C. 1991. The Ethics of Authenticity. Cambridge, Mass.: Harvard University.

BOURDIEU, P. 1984. Distinction. Cambridge, Mass. : Harvard University.

FRASER, N. 2001. Da redistribuição ao reconhecimento? Dilemas da Justiça na era pós-socialista. In: SOUZA, J. (org.). Democracia hoje : novos desafios para a teoria democrática contemporânea. Brasília: UNB. 
reconhecimento social a uma teoria das distinções sociais revelando seu potencial revelador das diferenças.

A idéia central de Taylor é que a formulação de sentido para nossas vidas ocorre com o estabelecimento de avaliações fortes. Dessa forma, a identidade sempre está relacionada com redes de interlocução - idéias, aliás, também discutidas por Nancy Fraser (1996; $2001)^{41}$. Taylor discute a temática do reconhecimento e das precondições sociais para que o respeito e a auto-estima transformem-se no ponto central para a construção de solidariedade. Há duas formas de reconhecimento social que também são formas de atribuição de respeito, auto-estima e formação da identidade: uma universalizante, que é o princípio da dignidade, e outra particularizante, que é o princípio da autenticidade. Pensar a formação da identidade tendo como ponto de partida a autenticidade. A questão central é antes de tudo o ideal da autenticidade e depois o ideal da dignidade. Nesse quadro, o interesse de Jessé Souza em apresentar Taylor, é a questão do reconhecimento social que tem como base a cidadania jurídica e política, na medida em que seu objetivo é refletir a respeito da sociedade brasileira como periférica e demonstrar como é possível, em um contexto formalmente democrático, aberto e pluralista, a formação de cidadãos de segunda e terceira classes.

$\mathrm{O}$ autor dedica um capítulo à abordagem do pensamento de "Pierre Bourdieu e à reconstrução da Sociologia crítica", por entender que ele desmascara a "ideologia da igualdade de oportunidades". De acordo com Bourdieu, todas as sociedades produzem formas de mascarar a dominação e tal fenômeno é encoberto pelo capital simbólico. Para Bourdieu, tanto o capital simbólico como o capital religioso apresentam-se quando o capital econômico é negado. Outra categoria é a da "distinção" que tem como princípio “separar e unir, constituindo, portanto, solidariedades e preconceitos de forma universal -

${ }^{41}$ FRASER, N. 2001. Da redistribuição ao reconhecimento? Dilemas da Justiça na era pós-socialista. In: SOUZA, J. (org.). Democracia hoje: novos desafios para a teoria democrática contemporânea. Brasília: UNB. 
tudo é gosto - a partir de fios invisíveis e opacos" (SOUZA, 2003a, p. 57). O capitulo três, “Taylor e Bourdieu ou o difícil casamento entre moralidade e poder", tem como objetivo “[...] desvelar o potencial constituidor e legitimador de 'distinções sociais', ou seja, diferenças sociais, tornadas naturais e legítimas, sob o véu mascarador da pretensa igualdade e universalidade que habita a noção de dignidade" (idem, p. 67). Jessé Souza busca não apenas pressupor a existência de consensos culturais por trás da distribuição desigual de bens e recursos escassos, mas sim demonstrar qual é esse consenso, quais seus princípios e como eles manifestam-se na vida social a partir de signos. Segundo o autor, a complementaridade entre a abordagem de Taylor e Bourdieu dá-se porque, se em Taylor falta uma teoria da contemporaneidade da luta de classes, ela está presente na análise de Bourdieu, que desmascara o caráter de classe presente nas sociedades modernas. Ainda para Bordieu a ideologia espontânea do capitalismo baseia-se na lógica de reprodução de suas instituições fundamentais: mercado competitivo e Estado racional centralizado. E isto será fundamental para a percepção dos conflitos sociais típicos tanto da modernidade central quanto da periférica, uma vez que não se pode negar a eficácia do poder constituidor e regulador da vida social em todas as dimensões, destas instituições.

Taylor na fonte dos Self ${ }^{42}$ vai recorrer ao "imaginário social" que significa o que as pessoas percebem como sendo seu ambiente social, percepção esta que segundo ele, quase nunca assume a forma explícita de teorias, mas que se manifestam ao contrário sob formas de imagens, estórias, lendas, ditos populares, etc. O imaginário social permite a précompreensão imediata de práticas cotidianas ordinárias permitindo um senso compartilhado de legitimidade da ordem social. Recorre também ao que ele chama de atitudinal, explicando que,

O modo mesmo como andamos, nos movemos, gesticulamos e falamos é formado desde os 
primeiros momentos pela nossa consciência de que nós aparecemos para os outros, que nós estamos no espaço público e que esse espaço é potencialmente perpassado por respeito ou desprezo, por orgulho ou vergonha. (Apud, Souza, p.38)

Estes mecanismos permitem identificar referências conceituais e o modo de operar que permitem a distinção social entre classes e grupos sociais distintos em determinadas sociedades.

Vale ressaltar também o que Bordieu chamou de "habitus", que seria um sistema de estruturas cognitivas e motivadoras, que configuram "um sistema de disposições duráveis inculcadas desde a mais tenra infância que pré-molda possibilidades e impossibilidades, oportunidades e proibições, liberdades e limites de acordo com as condições objetivas" (Apud, Souza, p.44).

\subsection{Status, papéis, dominação, má intenção e manipulação.}

O status é a posição que cada um ocupa na pirâmide social e conforme a posição social que o indivíduo ocupa, ele poderá ter status diferente de outros, que impliquem em direitos e deveres diferentes em situações específicas, podendo em algum caso, conforme seu prestígio ter até privilégios em função do valor social conferido à posição que ocupa. Em uma empresa existe status mais e menos elevado, o empresário, o diretor da empresa e o funcionário prestador de serviços gerais, certamente tem status diferentes e privilégios diferentes, o diretor pode, por exemplo, ter à sua disposição carro e motorista da empresa, uma vez que suas responsabilidades o levam a tomar decisões cruciais para a empresa. Neste caso o status adquirido é obtido em função das qualidades pessoais do indivíduo, de sua capacidade e habilidade.

O status em caso conforme o acima exposto, em momento algum pode garantir privilégios em relação à cidadania, dentro de um regime democrático, onde todos os cidadãos têm igualdade perante a lei. 
Durante o período colonial, conforme observou Tobias ${ }^{43}$ (apud OLIVEIRA, 1997, p. 48) o ideal para a família brasileira era ter um filho padre; e o próprio sistema educacional visava à formação do padre, uma vez que ele era o letrado da colônia, com um grande prestígio social e ser padre era um mecanismo de ascensão social. Todavia ser padre era um privilégio de poucos, era quase monopólio dos senhores de engenho, de um brasileiro rico.

No período imperial, o objetivo cultural mudou, com a criação dos primeiros cursos superiores de Direito, um em São Paulo, no Largo de São Francisco e outro em Olinda, no mosteiro de São Bento, começava a ser substituído o "mito do padre" pelo "mito do doutor”. Apenas uma minoria poderia aspirar este título, mas a educação no Brasil passou a ser orientada para a formação de bacharéis.

Na prática, a sociedade construiu um mecanismo que indica uma relação de dominação, mecanismo específico das sociedades pré-modernas ou modernas que permite desviar a atenção da realidade imediata, em que as relações sociais ganhem autonomia própria ao aparecerem como naturais e indiscutíveis, naturalizando relações que são contingentes e constituídas socialmente, que se tornam resistentes e servem a diversos objetivos. Assim, conforme Bordieu (apud, SOUZA, 2003, p. 48) "a forma que essa "illusio" assume, no entanto é histórica e mutável” e esse efeito mascarador ele chamou de capital simbólico, representando neste caso uma espécie de crédito social, sendo a única forma possível de acumulação quando o capital econômico é negado, permitindo também o que ele chamou de mais valia simbólica.

Existem alguns fatores que devemos considerar em relação à realidade brasileira, Chauí (2000) afirma que nossa sociedade é autoritária porque é hierárquica, uma vez que "divide as pessoas, em qualquer circunstância, em inferiores, que devem obedecer, e superiores, que devem mandar".

Ora em uma sociedade de recursos escassos, dominar algum tipo de capital que possa

${ }^{43}$ TOBIAS, José Antônio. História da civilização brasileira, 2. ed. São `Paulo, Juriscredi, 1972. 
permitir uma posição de privilégio parece ser o sonho de todos, mesmo que para isto se recorra à ação ilícita.

É comum o uso de títulos em nossa sociedade e, sobretudo na periferia, como indicador de status, privilégio e mesmo intimidação ${ }^{44}$, ainda que a utilização do título, em face da evolução social que possibilita que hoje haja uma melhor compreensão do mundo acadêmico, possa ser visto como ação criminosa.

Por exemplo, doutor é um título acadêmico, é um grau que se obtém realizando curso de pós-graduação stricto senso, que deve ser recomendado e reconhecido pela Coordenação de aperfeiçoamento de pessoal de nível Superior (CAPES) do Ministério da Educação (MEC). Implica necessariamente, no mínimo, em mais quatro anos de estudos após a graduação, sendo necessária a produção acadêmica de conhecimentos através da pesquisa e defesa pública de tese, que assegura conhecimentos específicos e especializados. Nenhuma entidade pode expedir e conceder grau e título de doutor, sem estar devidamente autorizada, sem passar pelo rito da Lei.

Os que usam um título fazendo referência a uma formação que não possuem incorrem certamente no crime de falsidade ideológica, definido no código penal, art 299 (omitir em documento público ou particular, declaração que ele devia constar, ou nele inserir declaração falsa), os contratos de prestação de serviços são documentos; incorrem também no crime de propaganda enganosa, definido no código do consumidor art. 66 (fazer

\footnotetext{
${ }^{44}$ Em 1983 o Mantenedor do C.A.D.A.M., Prof. C.D.L.M., foi à 36 a Delegacia de Polícia de Itaquera realizar uma queixa de invasão ao seu estabelecimento e dirigiu ao Delegado titular o tratamento de você, ao qual ele reagiu e ameaçou prender o professor por desacato à autoridade, dizendo que ele queria ser tratado por doutor. Ao que o professor indicou a placa sobre sua mesa que trazia a inscrição Bacharel e o nome do Delegado, afirmando que ela não indicava que ele tivesse feito um curso "de pós-graduação stricto senso e tivesse obtido o grau de doutor", e que pelas faixas etárias deles, o tratamento de você podia não ser formal, mas não era desrespeitoso, logo não cabia o desacato. O delegado indignou-se dizendo que ele era o titular da DP e fazia jus ao título. Foi necessária a explicação que o Estado tem poder de polícia e ele pela função tinha o poder que o Estado lhe delegava, mas que não incluía um título de doutor que ele proclamava e reclamava; demorou em entender que doutor é um título acadêmico e que não cabia desacato, foi necessário um membro da $\mathrm{OAB}$, que foi chamado, explicar porque ele não tinha direito ao título de doutor. O título normalmente, até hoje, na periferia, é utilizado como fator de intimidação. (Ver depoimento do senhor A.C, pai de aluno e advogado, na pág.213 em que contou o fato e que foi corroborado pelo professor, mas que não quis gravar a entrevista.)
} 
afirmação falsa, ou enganosa) uma vez que ao afirmar ser doutores para prestar importantes serviços como os de saúde, por exemplo, muitos médicos e cirurgiões dentistas afirmam ter uma qualificação que não possuem e alardeiam a realização de um curso que não fizeram, de um conhecimento que não produziram e de uma especialização que não detém, mas que serve para induzir os clientes a erros, portanto tiram vantagens disto, o que caracteriza estelionato, artigo 171 (obter para si ou para outrem, vantagem ilícita, induzindo ou mantendo alguém em erro), pois prejudicam sim os que fazem jus ao título de doutor, sem contar o estelionato cultural e o desserviço que prestam à educação, banalizando o título.

Por que tal crime é praticado abertamente, inclusive por quem devia coibi-lo, que são os Delegados de Polícia, Promotores, Juizes, Advogados, etc.? Existem cargos que possuem em torno de si uma liturgia, como é o caso do cargo e função de Juiz, que caracteriza o mérito, implica, portanto em tratamento diferenciado de Meritíssimo, mas doutor não. O título do Parquet, "Promotor de Justiça", esgota-se em si mesmo, é um excelente título, é de direito e não é necessário mais que isto, não cabe o engodo de Doutor. Até os cirurgiões dentistas cuja profissão e exigência de nível superior ocorreu em 1951, sendo, portanto muito recente, se auto-atribuem criminosamente o título de Doutor.

Por que tal conduta? A resposta é simples, na medida em que alguém se autovaloriza com o capital simbólico de um título que não possui, reforça sua auto-estima e incorre na ilusão de que ocupa o topo da pirâmide social, adquirindo privilégios, fazendo parte do grupo dominador e assim em consonância com o autoritarismo de nossa sociedade procura desmerecer e diminuir os que não recorrem ao crime da utilização do título que não possuem. Acredita assim, na distinção que o falso título lhe confere, e busca formar o "habitus" da dominação. Na prática este menosprezo aos outros e, sobretudo aos direitos alheios, explica grande parte da permissividade e da impunidade que é constante na 
periferia $^{45}$. É preciso deixar claro que não existe tradição que possa justificar a vantagem ilícita, ou seja, o crime. A valorização social de um não pode e não deve implicar na desvalorização de outro e recorrer a um título que não possui para se autovalorizar, tem uma clara intenção de desvalorizar quem não tem o título, é uma tentativa de reduzir a dimensão social do outro. Estes mecanismos são instrumentos que visam perpetuar a subcidadania.

\subsection{Realidade da escola na periferia e a educação para a cidadania nos}

\section{documentos oficiais}

A violência que mata por um simples par de tênis, sempre foi lugar comum na periferia e mais grave, começa a parecer como alguma coisa normal. Essa violência em épocas anteriores parecia respeitar a instituição escolar, ficava em seu entorno, hoje ela avançou para dentro da escola. Adolescentes morrem a tiros e professores são ameaçados nas escolas públicas da periferia. Dados da UNESCO em pesquisa 2003/2004, sobre o cotidiano das escolas, em relação à violência, apresentam um quadro de invasões por pessoas de fora da escola, bem como a possível existência de gangues nas escolas.

Os números mostram que 55,8\% das escolas públicas brasileiras já foram invadidas; $20,4 \%$ de alunos pesquisados afirmaram que existem gangues nas escolas; 25,7\% afirmaram que não existem gangues; e 53,8\% afirmaram não saber se existe ou não gangues nas escolas.

\footnotetext{
${ }^{45}$ O Estado pode através de uma ação simples prestar um enorme serviço à cidadania, qual seja, o de educar seus agentes para que saibam que o poder de polícia é poder do Estado, que o delega, portanto os agentes públicos têm funções delegadas, são autoridades administrativas, mas não são doutores e que títulos, sobretudo títulos falsos, não podem servir de fator de intimidação ou de abuso de autoridade contra a cidadania. Bem como as instituições de ensino e as entidades de classe como CRM, CRO, OAB, etc. devem ensinar os seus membros o que é e como se consegue o título de doutor e que o uso indevido é crime e que não existe crime pequeno ou crime grande, se a legislação estabeleceu que é crime, é crime e deve ser punido na exata proporção em que é tipificado como ato antijurídico, porque é evidente que a utilização indevida do titulo visa adquirir vantagens que de outra forma não seriam adquiridas, existe uma intenção clara ou dolosa de se praticar o estelionato. É preciso deixar claro, não existe tradição que possa justificar a vantagem ilícita.
} 
Os indicadores da pesquisa relativos a São Paulo foram os seguintes: 21,6\% afirmaram que existem gangues; $26,6 \%$ afirmaram que não existem e 51,8\% afirmaram não saber se as gangues existem ou não. A pesquisa não apresenta conclusões e os números não permitem apresentar uma conclusão sobre a existência ou não de gangues nas escolas, mas não deixa dúvidas sobre a violência ao se considerar o percentual de invasões. Assim parece haver fatores indicativos de que o exercício da cidadania é difícil e que em algumas circunstancias parece não ser possível, resta saber se é possível uma educação eficaz para a prática da democracia e exercício da cidadania neste meio violento e adverso.

Sob o signo do projeto democrático-popular, foi inserido na Constituição aprovada em 1988 um complexo de direitos sociais que, ao menos formalmente, tinha como paradigma o Estado de Bem-Estar Social. A Constituição Federal estabelece no Artigo 205, que a educação é direito de todos e dever do Estado e da família e que visa o pleno desenvolvimento da pessoa e seu preparo para o trabalho e o exercício da cidadania. Em concordância com a carta magna, a Lei n 9.394/96 de 20 de dezembro de 1996, que estabelece as diretrizes e bases da educação nacional, em seu Artigo $2^{\circ}$ reitera a afirmação que a educação tem como finalidade o preparo para o exercício da cidadania e a qualificação para o trabalho.

Em 1997, o Ministério da Educação e do Desporto (MEC) recomenda e envia para apreciação da Câmara de Educação Básica (CEB), os Parâmetros Curriculares Nacionais para as quatro primeiras séries ${ }^{46}$ da escolaridade obrigatória, que estabelece logo em seu princípio a compreensão da cidadania como participação social e política, assim como os direitos e deveres políticos civis e sociais, preconizando atitudes de solidariedade, cooperação e de repúdio as injustiças.

Em 1998, atendendo dispositivo legal o Conselho Nacional de Educação (CNE) através

${ }^{46}$ volume 10, Parâmetros Curriculares Nacionais, Objetivos Gerais do Ensino Fundamental. Brasília: SEF. 1997. 
da Câmara de Educação Básica (CEB), elaborou o Parecer $\mathrm{n}^{\circ}$ 15/98, aprovado em 01/06/98, apresentando propostas de regulamentação da base curricular nacional e de organização do Ensino Médio e ao discorrer sobre a política da igualdade avalia que:

Incorpora a igualdade formal, conquista do período de constituição dos grandes Estados Nacionais Seu ponto de partida é o reconhecimento dos direitos humanos e o exercício dos direitos e deveres da cidadania, como fundamento da preparação do educando para a vida civil (PCN-Ensino Médio. p.76).

A temática da formação da cidadania, conforme nossa legislação de ensino, mantém-se como um dos eixos básicos da finalidade da educação. Mas se a educação para a cidadania parece ser um imperativo social, o dilema é saber se a educação desenvolvida em instituições de ensino pública e privada da periferia da grande metrópole tem atingido seus objetivos. 


\section{CONSIDERAÇÕES FINAIS}

Ao alinhavar as questões levantadas pelos atores do presente trabalho, sobressaem alguns aspectos que parecem de extrema importância, até pela forma recorrente que aparecem em quase todas as falas.

\section{O questionamento da democracia}

Ao questionar a democracia como algo que não funciona, ou ao afirmar que é uma democracia para poucos e que é preciso começar tudo de novo ocorre a percepção de que as formas tradicionais de representação na democracia não garantem inserção de algumas minorias e de outras vastas maiorias, leva à relativização da representatividade e remete a busca de novas soluções para a inclusão da diferença.

O modelo de democracia representativa percebida na periferia, que parece ancorar-se no modelo competitivo levou o cidadão da periferia a não acreditar no funcionamento da democracia. Ao que parece o povo não participa das decisões e percebeu que sua participação tem sido apenas votar nas eleições.

Percebe-se também que as criticas surgiram como decorrência da situação de não deliberar e participar efetivamente das decisões, os cidadãos sentem-se alijados e incomodados, recorrendo ao discurso de que é preciso mudar tudo, o que realmente implica em reorganização do Estado democrático brasileiro e certamente dentro de aspectos mais amplos do conceito de democracia representativa participativa e deliberativa.

Os entrevistados colocam as esperanças na educação, acreditando que ela seja o caminho natural para que a comunidade adquira respeito e se organize melhor. Todos parecem dominar a definição amplamente conhecida e divulgada de que democracia é "o 
governo do povo, pelo povo e para o povo". Demonstram saber que as definições têm variado ao longo do processo histórico, apoiando-se em um fundamento básico em que se admite que a democracia é o poder da maioria, representando, portanto a soberania do povo. Já outros consideram que a democracia tem sua base na igualdade perante a lei. Existem os que identificam a democracia com a liberdade e concebem o regime democrático como aquele que assegura a autodeterminação política do cidadão, como essência fundamental da formação da vontade estatal.

Acreditam que o objetivo fundamental do regime democrático deveria ser o de buscar e tornar efetivo o governo da maioria e, ao mesmo tempo, preservar as liberdades e os direitos da minoria. Entendem que isto acaba sendo a garantia do poder da maioria em realizar o bem estar geral, com a participação efetiva da minoria, que acaba por fiscalizar as ações da maioria.

O sentimento de revolta é recorrente devido à idéia que eles têm de que o regime democrático possui princípios constitutivos que assegura aos cidadãos a igualdade de todos perante a lei; participação no governo pelo direito do sufrágio; e governo eleito pela maioria e de que Democracia é o regime político que assegura que a vontade dos governados, através da representação política, deve influenciar e ser respeitada nas decisões dos governantes, na elaboração e promulgação das leis. Os representantes são eleitos através do voto. O exercício do poder do povo através de representantes é o que se chama de democracia indireta, porque em última instância a vontade do povo está prevalecendo por intermédio de que o representa, daqueles ele escolheu por intermédio de eleições para representá-lo. Não acreditam que estejam sendo representados conforme suas vontades e que todos que se elegem não se importam com isto.

Aqui cabe lembrar Chauí (2000) que ensina que ao longo do período de guerra fria no século passado, a democracia acabou sendo reduzida em diversos momentos a uma simples 
ideologia política, recorrendo a critica realizada por Marx que ela acaba sendo "um mero formalismo jurídico que preside a idéia de direitos do cidadão".(CHAUI, 2000, p. 430), o que em essência concorda com o sentimento de frustração que o morador da periferia têm em relação à democracia.

A mesma autora critica ainda, a forma de ser ver a democracia como um regime político eficaz, baseada na idéia de cidadania organizada em partidos políticos e manifestando-se no processo eleitoral de escolha de representantes, na rotatividade dos governantes e nas soluções técnicas para os problemas sociais, o que o povo na prática também demonstra saber.

O povo consegue apreender que existe na prática democrática algo mais profundo que a ideologia democrática, que as eleições deveriam significar realmente mais que a rotatividade de governos e sim, que o poder, não pode se identificar com seus ocupantes e que maioria e minoria, situação e oposição demonstram que democracia é realmente a única forma política que considera o conflito como legítimo e legal e sem ódios ou ressentimentos, fazendo com que ele seja trabalhado politicamente pela sociedade e continua acreditando que a essência da democracia é a instituição de direitos. É possível concluir que o povo sabe que democracia, sendo fato histórico sociológico, está permanentemente sendo construída, daí as veementes colocações de que é preciso reorganizar e começar tudo e novo.

\section{O questionamento do Judiciário}

Outro tema recorrente é o questionamento do poder Judiciário, enquanto poder de Estado que deveria ser garantia de acesso à justiça. O acesso à justiça, segundo $\operatorname{Cintra}^{47}(2003)$.

\footnotetext{
${ }^{47}$ CINTRA, Antonio Carlos de Araújo e outros. Teoria Geral do Processo. São Paulo: Malheiros 2003, p.
} 
não se identifica, com a mera admissão ao processo, ou possibilidade de ingresso em juízo. (...) Para que haja o efetivo acesso à justiça é indispensável que maior número possível de pessoas seja admitido a demandar a defender-se adequadamente. O acesso à justiça é, pois a idéia central a que converge toda a oferta constitucional e legal desses princípios e garantias.

O Direito geralmente é definido como sendo o conjunto de normas dotadas de poder institucionalizado de coerção que regulam a vida social ${ }^{48}$; Como o conjunto de direitos e obrigações dos cidadãos e das pessoas jurídicas que o Estado reconhece e assegura. Em qualquer das duas hipóteses, podemos pensar o Direito ou como criação do Estado, ou, inversamente, o Estado como criatura do Direito. Por paradoxal que pareça, as duas afirmações estão corretas. Não há Direito sem Estado nas sociedades modernas, já que não haverá norma jurídica se não houver a correspondente possibilidade de sanção pelo Estado. Segundo Bresser-Pereira ${ }^{49}$ (2003), podem existir normas costumeiras, tradicionais, mas não chegam a se constituir em Direito no sentido estrito do termo. Por isso pode-se afirmar que o Estado - a organização com poder de legislar e tributar a população de um determinado território - cria o Direito. Mas o inverso também é verdadeiro. Não é possível falar em Estado sem o Direito. O Estado se define a partir da norma constitucional. Surge um Estado quando um conjunto de indivíduos se afirma como cidadãos ao formularem e darem vigência ao conjunto de normas que constitui o Estado.

O poder Judiciário (judiciário literalmente significa dizer o direito, Iuris = Direito e Dicção $=$ dizer), que personifica o poder do Estado de dizer o Direito, é visto como inexistente, como um antro de corrupção, como algo de acesso de poucos, como um instrumento à serviço dos poderosos e como oneroso, inútil e mais ainda, como extremamente nocivo à sociedade, chega a ser acusado pelos cidadãos como o responsável direto pela violência. É uma instituição absolutamente desacreditada, sobre a qual afirmam

\footnotetext{
${ }^{48}$ Bobbio (1958: 111-113) enfatiza o caráter institucionalizado da garantia da norma jurídica. Para ele o que caracteriza a norma jurídica é o poder de coerção externo, desde que institucionalizado, distinguindo-se, assim, dos poderes de tipo mafioso, que também são dotados de coercibilidade.

${ }^{49}$ Revista de Filosofia Política - Nova Série, vol.1, 1997: 99-144 (Porto Alegre: Universidade Federal do Rio Grande do Sul, Departamento de Filosofia).
} 
ser necessário começar tudo de novo e certamente dentro de moldes diferentes, afirmam diretamente a necessidade que é preciso controlar e limitar o poder dos juízes. Falam até em conselhos constituídos pela comunidade aos quais tudo deveria ser submetido.

As acusações de prepotência e arrogância dos juizes, ao lado da afirmação de que os juizes parecem querer humilhar a sociedade, contrariando-a sempre, utilizando a mesma lei que pode punir, sempre para absolver, apenas para mostrar que podem, mesmo no caso de crimes hediondos, em que a sociedade clama por justiça; quando um aluno chega a dizer que o mata-mata diário é estimulado pelo judiciário, que garante o direito de matar impunemente, mesmo com o ato sendo tipificado como antijurídico, como crime, com punição prevista em lei. Os juizes acabam sendo legisladores e legislando, inclusive em causa própria, com salários que realmente humilham a sociedade. Alguns atos dos juízes demonstram que eles se colocam acima da própria Lei $^{50}$.

A critica ao ritualismo da justiça que passa anos julgando apenas a formalidade de um processo, sem sequer entrar no mérito da questão do direito; em que o cidadão perde anos na justiça para ter julgado a forma, o ritual, do que solicitou e não o seu direito como o caso citado pelo advogado entrevistado, sem que o judiciário se preocupe com o direito e com o atentado à normas constitucionais; e parece ser realmente grave, que as sentenças sejam elaboradas por técnicos judiciários, dentro de um contexto em que o juiz não lê o processo. Ora, em sendo tal acusação verdadeira e com tudo o que foi exposto, pergunta-se: para que juiz?

Um dos entrevistados não quis gravar na entrevista, mas ventilou a possibilidade da justiça ser um simples órgão administrativo, do poder executivo, pois assim seria mais fácil realizar mudanças, controlar e punir juizes, pois a insatisfação seria demonstrada pelo voto e as queixas seriam apresentadas a um superior administrativo e seria mais fácil de cobrar,

\footnotetext{
${ }^{50}$ Ver caso de Serrana, em que juiz intimou criança de 5 anos e mandou força policial para conduzi-la a sua presença. Noticia disponível no site http://www.juspodivm.com.br/noticias/noticias_1213.html
} 
afirmando que o judiciário hoje, com o poder dos juízes é perigoso para o cidadão. Isto demonstra que o descrédito do judiciário é tanto que povo não o reconhece como um poder necessário para o equilíbrio dos poderes e como um dos pilares de um regime democrático. Na prática, a fala do cidadão, se não implica na eliminação do judiciário como um poder, deixa claro que precisa ser desenvolvido mecanismo que efetivamente o controle, que como está, ele não pode permanecer, que a continuar assim, é melhor eliminá-lo. Outros chegaram a achar que forma de constituição e organização do Judiciário em alguns Estados Norte-Americanos, em que os juízes são eleitos pelo voto popular e com mandato estabelecido, seria melhor para a cidadania. Pois acreditam que o acesso por concurso, por meio de uma simples prova ou avaliação de conhecimento, que dá direito à vitaliciedade, concentrando tanta imunidade e muito poder, é o caminho natural da corrupção, arrogância e prepotência. Acreditam realmente que estamos à mercê de um poder sem limites e que é uma das causas principais da violência no mundo em que vivem.

\section{A questão policial}

A questão policial é muito séria, porque o povo acha que a polícia não sabe o que está fazendo, inclusive acredita que especialista em segurança são as vítimas da violência, que é o cidadão trabalhador, morador da periferia e que suas atividades deveriam ser organizadas e planejadas por meio de conselhos comunitários, aos quais a polícia deveria ser subordinada, o que a levaria a prestar melhores serviços. A polícia é visível, ela está presente e ao lado das instituições escolares é outro equipamento social indispensável e suas atividades na periferia são claramente perceptíveis. Ocorre, porém, que a sua atuação quando positiva, não é comentada, porque é uma mera obrigação, todavia, ampliam a sua atuação negativa porque conseguem visualizá-la praticando atos de violência contra o trabalhador e na rotineira prestação de serviços que ela faz aos poderosos locais. Ela é considerada o maior problema para o morador da periferia, que não a respeita, por que a 
coloca no mesmo nível do demais marginais, mas que tem medo, muito medo da polícia. Em Artigo publicado no Jornal da Tarde em 20/07/2000, intitulado CARANDIRU II, o Cel. José Vicente da Silva ${ }^{51}$ afirma que:

Nem os porões da ditadura ousaram tanto. O Estado de São Paulo, o mais rico, o das melhores universidades, o de maior expressão cultural do País, vivendo um governo democrático num Estado de Direito, fuzilou pelo menos 60 pessoas inocentes no ano passado. Neste ano deverá fuzilar o dobro, pela excepcional produtividade da Polícia não em reduzir crimes, mas em matar. Teremos um número equivalente ao da matança promovida pela PM no Carandiru em 1992". (José Vicente da Silva Filho é coronel da reserva da PM)

Ele diz que quem trabalha para que as leis sejam observadas é a própria Polícia, que parece estar acrescentando novas leis, formas especiais de julgamento e de execução da pena. Acrescenta que a própria Secretaria de Segurança Pública reconhece que, em pelo menos $10 \%$ dos mortos pela Polícia, houve excesso e suspeita de execução. Afirma em seguida que "A letalidade da polícia paulista parece descontrolada. Metade dos mortos em supostos confrontos tinha tiros nas costas e um terço recebera bala na cabeça”.(José Vicente da Silva Filho é coronel da reserva da PM)

Segue afirmando que esses dados foram pesquisados pela Ouvidoria da Polícia, trazendo à luz o que sempre ocorreu com a complacência dos chefes e responsáveis pelos inquéritos. Essa complacência pode ser constatada em pelo menos um fato: em quase três quartos dos casos as vítimas "morreram" no hospital. As justificativas dos chefes policiais podem até parecer profissionais, mas na verdade buscam proteger a organização de seus erros, ou não querem reconhecer a letalidade excessiva da ação dos policiais. Para ele, o argumento de que os tiros nas costas se devem ao fato de que os bandidos atiram enquanto fogem é simplesmente ridículo. Informa que na maioria das polícias americanas adota-se um eficiente sistema de controle: simplesmente o policial é proibido de atirar em alguém que esteja fugindo, até para se evitar que balas perdidas atinjam inocentes. Entende que a

\footnotetext{
${ }^{51}$ José Vicente da Silva Filho é coronel da reserva da PM, mestre em psicologia social, pesquisador de segurança pública do Instituto Fernand Braudel de Economia Mundial e consultor do Banco Mundial. Artigo disponível no site:

http://www.braudel.org.br/novo/index.php?old=http://www.braudel.org.br/novo/instituto/pesquisadores/jvs j $\mathrm{j} / 2000 /$
} 
situação decorre da violência crescente da delinqüência, até por falhas do sistema preventivo da Polícia e das deficiências de nossas leis penais e de execução criminal. E admite que "não cabe à Polícia compensar a defasagem do sistema jurídico fazendo suas próprias leis. Ocorre que à medida que a polícia vai se tornando mais violenta, os bandidos supõem que serão mortos ao serem abordados e reagem com mais violência”.(José Vicente da Silva Filho é coronel da reserva da PM).

Conforme o mesmo autor, nessas cirandas infernais de violência, que o próprio Estado patrocina e os chefes defendem, os policiais também são vítimas. No serviço de policiamento, nas delegacias, no bico ou quando meramente identificado em sua folga, o policial passa a ser alvo da fúria vingativa dos bandidos. Segundo ele a cúpula da Polícia prefere usar os cadáveres dos policiais para justificar sua forma de trabalho em vez de pranteá-los e implantar medidas para conter esse círculo de violência. E conclui dizendo:

\begin{abstract}
Só quem conviveu intimamente com o dia-a-dia dos policiais pode entender como esses mecanismos de complacência, entendidos como incentivos, fazem, de bons policiais, cruéis matadores. Se a Polícia não controla seus próprios policiais é necessário que o governo do Estado, que a comanda, tome as medidas necessárias. Não vamos pretender que reforme a instituição policial para que se torne mais competente no trabalho de prevenção. Apenas faça com que a Polícia se comporte como órgão fiscalizador da lei num país democrático e a faça entender que não se admite a repressão violenta como mecanismo de prevenção. Duzentos ou mil bandidos mortos não valem a vida de um único inocente, civil ou policia. (José Vicente da Silva Filho é coronel da reserva da PM)
\end{abstract}

Em seguida o autor lamenta, a quase inexistente repercussão da divulgação dos dados pela imprensa, sem maiores comentários pela televisão, cartas dos leitores ou protestos de entidades legislativas e de direitos humanos. Conclui que se a sociedade não pressiona para que o regime democrático de um Estado de Direito seja respeitado em todas instâncias, o edifício da democracia começa a trincar em suas fundações.

Ao artigo do coronel poderíamos acrescentar que a polícia sente-se uma instituição acima do bem e do mal, acima do próprio Estado e que acredita que sua violência sistemática contra o trabalhador pobre da periferia, com rotineiro abuso de autoridade, realmente ajuda a garantir a segurança, mas é preciso ressaltar que a polícia na periferia 
também tem medo, é constituída por seres humanos, que conhecem a violência do meio em que vivem e tem um agravante, é composta por pessoas legalmente armadas, o que a torna muito perigosa para o cidadão. Evidentemente que o cidadão não acredita nas corregedorias de polícia, para ele elas continuam sendo polícias, logo comprometidas com a instituição à qual pertencem, corporativistas e por isto ventilaram a possibilidade de uma polícia independente das instituições policiais existentes para apurar e punir os crimes da polícia. O cidadão chegou a dar uma denominação "polícia da cidadania, independente, separada e formada especialmente para atender, socorrer e impedir que alguém seja vítima da polícia”.

Na prática o artigo enfoca todos principais ângulos da questão policial na periferia e tudo o que ele disse sobre a violência policial e geral, parece reproduzir o que o povo pensa e diz. Não restam dúvidas de que a população quer uma polícia que esteja a serviço da comunidade e pronta para atendê-la, porque só o efetivo poder da polícia pode fazer com que a cidadania seja respeitada. A periferia neste momento, segundo seus moradores, parece ser realmente terra de ninguém, em que prevalece o mais forte, o que ressalta a importância e a necessidade de uma polícia preparada para atuar em defesa da cidadania, mas fica claro que é preciso articulação da sociedade para mudanças na participação democrática, na legislação e no poder judiciário.

\section{Subcidadania}

O sentimento de subcidadania aparece em quase todas as falas, percebido como um processo de discriminação da periferia, como uma forma de inferiorização em que a cidadania comparada com cidadãos de áreas mais nobres da cidade parece ser mais plena e diferenciada inclusive na forma como é tratada pela própria policia, que são agentes do Estado. O que parece deixar claro que o autoritarismo e a violência institucional contra os 
despossuídos, em nossa sociedade tem raízes coloniais e pode se constatar pela análise do processo histórico que estes problemas corriqueiros na periferia não nasceram agora com o dito neoliberalismo, como querem alguns autores, eles já estavam ai e ao longo do trabalho procurou-se caracterizar de uma forma clara o que seja as dificuldades de se viver, conviver e se educar na periferia, evitando-se o paradigma teórico marxista-estruturalista, preconizado por Castells (1983) - no qual as cidades capitalistas eram examinadas exclusivamente à luz do conceito-chave de "modo de produção" - vale dizer, onde tudo aquilo que não fosse diretamente relacionado com a acumulação do capital e as contradições de classe, deveria ser visto como de importância secundária.

Existem bairros nobres que nasceram ontem, no dizer da população e bairros periféricos, como os aqui estudados que têm mais de trezentos e cinqüenta anos, formaramse quase que na mesma época do próprio núcleo central que deu origem a cidade de São Paulo e o investimento em equipamentos sociais e infra-estrutura urbana, que se fez em ambos, que inclusive os caracterizam como pobre e nobre, deixam claro a diferença de tratamento. Portanto este sentimento de subcidadania não é por acaso, ele parece refletir o tratamento que o Estado dá à periferia, daí a justificativa para o sentimento de revolta e de que é preciso mudar tudo.

\section{Observações}

Os fatos alinhavados levam a crer que a população da periferia sabe com certeza o que não quer. Não quer uma democracia representativa que parece não representá-la; não quer que se tomem decisões que não passe pela consulta de sua vontade; não quer o poder concentrado em nenhuma instituição, seja executiva, legislativa ou judiciária; não quer um judiciário que se sobrepõe a tudo, que se coloca acima da cidadania e não atende o cidadão; não quer juízes vitalícios, nem juizes monocráticos, nem o juiz detendo soberanamente o 
poder de decisão; não quer o poder de decidir fora do controle da sociedade e conseqüentemente do controle do cidadão; não quer "forum" privilegiado para nenhum tipo de autoridade ou ex-autoridade; não quer que a decisão de onde e como a polícia deve atuar, não seja uma decisão sua, uma vez que por ser ela, população, quem corre os riscos, sabe como evitá-los e como combater os que a ameaçam; não quer ser vista e tratada como sendo inferior, conseqüentemente não quer o tratamento de subcidadania.

Ora, o fato de saber o que não se quer é um indicativo do caminho daquilo que se quer, todavia o que ela parece não saber é como realizar a reforma que ela vislumbra como necessária, ela não consegue balizar o caminho que leve o cidadão ao controle direto de todo e qualquer mecanismo de poder de decisão do Estado, ela sabe que o povo deve ser e ter o poder, mas não sabe como realizar democraticamente esta verdadeira revolução política e social.

\section{A educação}

Abrangeu-se um período histórico de enorme importância para a formação da periferia, colocando-se os diversos cenários ao longo do tempo, até que se chegou ao cenário atual, expondo-se as dificuldades que caracterizam o cotidiano da periferia.

Buscou-se também definir e caracterizar os conceitos e as dimensões da cidadania. Por força da discussão temática abordou-se também o que alguns autores vêm considerando como subcidadania e sua origem histórica e qual a ótica do Estado acerca da cidadania evidenciando como o Estado não consegue atender as populações mais pobres na periferia.

Ao se dar a palavra aos protagonistas do trabalho, em diversos momentos sentiu-se que as dificuldades que foram expostas ao caracterizar o cotidiano da periferia parecem ter sido corroboradas, na percepção clara de que a região tem um tratamento diferenciado daquele dado às centralidades urbanas, parecendo que mais do que nunca se admite a subcidadania, 
dentro daquilo que Marcelo Lopes de Souza (1996, p. 455) $)^{52}$, ao procurar demonstrar um quadro da realidade urbana do Rio de Janeiro, que tem pontos de semelhança com São Paulo, chamou de equação simplista, expondo assim: "favelados = vagabundos + desajustados, substrato ideológico do velho mito da marginalidade".

Lúcio Kowaric ${ }^{53}$, no livro Trabalho e Vadiagem: A origem do trabalho livre no Brasil busca demonstrar no curso da história social brasileira aquilo que a sociologia dos anos 60/70 do século passado estudou sob o conceito de "marginalidade". Detendo-se nas primeiras décadas do século, o livro é de uma surpreendente atualidade, levando-nos a detectar nas condições atuais de trabalho no Brasil ecos das falas e práticas patronais de muitas décadas passadas, bem como o tratamento que se dá ao trabalhador. O morador típico da periferia continua a ser o pobre ou "vagabundo", por força do desemprego. A forma de olhar o pobre no século vinte e um parece não ter mudado nada, com a ressalva de que hoje o pobre sabe como é visto, ou seja, como subcidadão.

A consciência de subcidadania em todas as falas, parece ter sido incorporada por todos moradores da periferia que se acostumaram à discriminação, que embora pareça natural, causa uma revolta inconsciente, hoje aparecendo como indisciplina e agressividade por parte dos alunos que ameaçam os professores, que sendo funcionários públicos e membros de uma instituição governamental, representam, o poder público, contra o qual os alunos demonstram querer insurgir-se. Aparece claramente a descrença no poder político e em alguns casos a mensagem subliminar de ausência de expectativa de vida.

É possível perceber, conforme palavra dos próprios atores educacionais, que os níveis de pobreza urbana e a falta de acesso real à educação parecem se concentrar em sua maioria na periferia, onde hoje se percebe um agravante que é a constatação de domínio da

\footnotetext{
${ }^{52}$ In: SOUZA, Marcelo Lopes de. Questões Atuais da Reorganização do Território -As drogas e a "Questão Urbana" (p.419 - 464) no Brasil.Rio de Janeiro: BCD União de Editoras: 1996.

${ }^{53}$ KOWARIC, Lúcio. Trabalho e Vadiagem: A origem do trabalho livre no Brasil. Rio de Janeiro, Paz e Terra, 1994.
} 
região pelo crime organizado, evidenciando um encolhimento ou ineficiência do Estado, que contribuiu para a criação do vácuo de poder e legitimidade estimulador da "ordem ilegal que é o crime organizado".O Primeiro Comando da Capital (PCC), que simboliza o crime organizado, que parece, hoje, ser a única instituição com força, na periferia, para impor seu domínio 54 .

Dentro deste contexto, é possível falar na ausência de uma ordem formal representada pelo Estado; falar em "vácuo de poder" que está sendo preenchido pelo dito Primeiro Comando da Capital, que se percebe no tráfico e consumo aberto e declarado de drogas na periferia, inclusive dentro dos veículos de transporte coletivo, como trem, metrô, ônibus, vans, que servem a região.

Hoje parece haver uma situação onde impera a truculência, a polícia é violenta e o tráfico é cruel; crianças são mortas impiedosamente, bem como jovens e adultos, por dividas que não ultrapassam alguns centavos.

Todos os envolvidos com o processo de educação sabem que a escola tem uma função e por mais que saiba seu papel, e por maiores que sejam as expectativas em torno de si, como representação de um mecanismo que possibilita a ascensão social, ficou clara a dificuldade que ela encontra para exercer sua função.

Evidenciou-se também que não se pode responder ao medo do professor com cursos de capacitação, uma vez que este supostamente tem perdido o controle de crianças em salas de aulas, que já manifestam uma latente revolta e agressividade, que caminha para a violência. Paralelamente à capacitação do professor, são necessários investimentos, é preciso que o Estado esteja presente com equipamentos e recursos que atendam o mínimo de direitos

\footnotetext{
54 Segundo depoimentos em que os entrevistados não querem ser identificados, os lideres do crime organizado, chamados na periferia de colunas, arbitram até a partilha de bens ou pagamento de pensões em separação de casais e estabelecem quem pode e quem não se pode matar em questões de disputa entre marginais e ou conflitos com ou entre cidadãos comuns. Delimitam área de atuação entre os criminosos para a pratica de roubos e outros crimes. São procurados por moradores das comunidades locais para impor a ordem.
} 
sociais dos alunos e dos pais dos alunos, ou seja, da comunidade periférica, no que tange a trabalho, moradia, educação, saúde e lazer.

Ressalte-se que o professor, mesmo o da instituição particular de ensino, não deixa em momento algum de ver a questão da educação como algo afeto e pertinente ao poder público e que ela deve passar, portanto, pela escola pública; que está presente e que talvez seja o mais importante equipamento social do Estado; que tem a responsabilidade, na periferia, de atender o maior contingente populacional. Quem atende a maioria, se fizer um atendimento adequado, estará contribuindo para a melhor qualidade de vida de todos, uma vez que a educação repercute sobre toda a sociedade.

Apesar de todas as dificuldades e que são bem maiores do que a princípio podia se supor, os jovens da periferia ainda conseguem ter a noção de cidadania, quando falam em igualdade de direitos e sabem que existe um problema social grave que passa pela droga e desemprego e estes resultados auferidos deixam claro que é possível a educação para a cidadania, mas que o trabalho certamente é muito árduo.

\section{Educação e consciência}

Existem problemas que são comuns às duas instituições, que recebem tratamentos diferenciados e muitas vezes o que parece ser um problema conjuntural de gestão não o é e outras vezes pode sê-lo. Na escola pública as crianças apresentam problemas de indisciplina, e dificuldades gerais; convocam-se os pais, que não comparecem. Mas que fique claro, a responsabilidade nunca fica nas mãos dos pais, comparecendo ou não, para os pais o problema da indisciplina é algo que deve ser resolvido pela instituição escolar, o problema fica sempre com a direção da escola. Na escola particular também ocorre indisciplina e a instituição observa o aluno para saber se ele tem problemas de saúde congênitos ou situacionais, após o que, convoca os pais, encaminhando-o para os diversos 
tipos de especialistas que possam ajudá-lo, procurando resolver o problema. Aqui pode ficar a impressão de que o aluno da escola particular tem melhor poder aquisitivo, sendo que por isto está na escola particular. A conclusão é simplista. O poder aquisitivo não é o fator preponderante, a diferença está na "consciência", que é uma "atividade mental que nos permite estar no mundo com algum saber "com-ciência" (COTRIM, 2000, p.42). A maioria dos pais da escola particular realiza sacrifícios para manter seus filhos na instituição, pois além de buscar o que chamam de uma melhor qualidade de ensino (o que pode acabar não sendo verdade), buscam, sobretudo, segurança (e aqui sim o serviço privado é melhor), seus filhos não serão vítimas de violências e terão seus direitos respeitados; direitos estes que começam pelo respeito à saúde. Portanto, a primeira grande diferença está nos pais. Um pai não comparece e o outro é convocado porque certamente comparece, inclusive, sem ser convocado, logo não é um problema de gestão e isto nenhuma direção escolar poderá mudar. Todavia, quando se coloca a questão, observa-se e avalia-se a criança para identificar o problema, fica claro que é um problema de gestão, pois a escola pública também tem a obrigação de adotar este procedimento.

A grande queixa que se faz em relação à escola pública, não é relativa ao atendimento ou à qualidade do ensino propriamente dito e sim ao processo de violência ao qual ela está exposta, a queixa é de que os marginais a freqüentam e a controlam, o que parecer ser um problema estrutural que escapa à questão de gestão administrativa, devolve a questão à segurança, volta a ser uma questão policial e que o Estado tem como resolver, é preciso ter vontade e entender o que realmente acontece na periferia.

\section{Fazer valer os direitos}

Um pai corresponde e outro não, talvez por isto possa parecer utópico convocá-lo para solicitar que leve o filho ao oftalmologista (normalmente os pais procuram resolver o 
problema pedindo para colocar a criança sentada na frente, porque ela não enxerga direito) ou ao psicólogo, não restam dúvidas é uma tarefa difícil, mas que precisa ser feita, ou a criança estará sendo desrespeitada. Como fazer? Primeiro a escola não pode esquecer que existem mecanismos como o Conselho Tutelar e ou o Juiz da Vara da Infância e Juventude, que devem ser acionados para obrigar o pai a comparecer ${ }^{55}$. É preciso orientar o pai a procurar a Procuradoria do Estado, o Ministério Público, a Defensoria Pública para que se obrigue o serviço público, sobretudo os de saúde, a atender os cidadãos. A criança tem direito a psicólogo, fonoaudiólogo, médico, etc. Tais medidas educam os pais e também os prestadores destes serviços, porque muitas vezes o Estado oferece o profissional, que não age corretamente, pois relembramos Damiani (2005) "na periferia tudo parece ser provisório", inclusive profissionais e serviços. A questão é trabalhosa, mas precisa ser feita e quem deve fazer é quem tem a obrigação de educar e isto certamente implica em riscos, ser professor na escola pública da periferia, fazer o que precisa ser feito, é realmente arriscado, não por causa dos alunos, mas por causa da sociedade violenta que cerca a escola. Novamente recorremos ao grande ausente, o Estado, ele precisa garantir no mínimo, o direito do educador educar.

\section{Preparação do professor}

A preparação do professor é algo realmente muito importante, ele não deve apenas dominar conceitos de cidadania, deve antes de tudo saber como funcionam os instrumentos que possibilitam o exercício da cidadania. A representação que tanto o aluno como a

\footnotetext{
${ }^{55}$ Um policial militar que prestava serviços (bico) à instituição particular de ensino, relatou que estava em seu plantão e um cidadão de uma favela das proximidades foi até a sua viatura informá-lo que um membro do Conselho Tutelar de Guaianases, foi convocar um pai em uma favela e que estava detido em cárcere privado e sendo torturado. O policial pediu reforço para entrar na favela e quando entraram para fazer o resgate, receberam a informação de que o membro do Conselho Tutelar ficou vivo apenas para levar o recado de que não voltassem lá. Não sabemos se o relato é verdadeiro ou não, tudo leva a crer que sim, contudo isto demonstra que as coisas na periferia são diferentes, não basta ter mecanismos institucionais é necessário poder, é preciso que o Estado esteja presente para que eles possam funcionar e poder não é violência contra o cidadão de bem, é fazer valer a lei.
} 
comunidade faz do professor é a de que ele é alguém que sabe, por isto ele tem que estar preparado para desempenhar o seu saber.

O educador não pode se omitir deve ser alguém capaz de instrumentalizar o aluno para proteger ou fazer valer seus direitos. Ele tem que saber como funcionam os mecanismos institucionais, começando pelo Ministério Público, que no dizer dos moradores, é absolutamente inútil na periferia, uma vez que, por exemplo, quer processar pessoas cumpridoras de seus deveres que tiveram seus muros derrubados por enchentes, que tem endereço e domicílio conhecidos, mas são absolutamente incapazes de mover uma ação por prevaricação de autoridade, mesmo vendo a omissão que as autoridades praticam.

O Ministério Público, conforme alguns entrevistados colocaram, busca os holofotes, quer aparecer em casos que dão publicidade e se possível se promover demonstrando uma terrível intransigência e autoridade, que na prática é autoritarismo, contra trabalhadores comuns, mas tem medo de enfrentar ou demonstram absoluto descaso com os problemas que realmente afligem a periferia. Mas como disse uma professora, apesar disto, ele precisa ser acionado, talvez assim consiga se desenvolver e prestar os serviços para os quais foi constituído.

Talvez o próprio poder público devesse integrar todos os mecanismos institucionais, junto às instituições de educação, de forma que acionando uma fosse possível acionar todas, certamente, isto iria fazer funcionar a segurança nas escolas e eliminaria o mais grave problema que a educação pública enfrenta na periferia: a violência em suas portas.

\section{A educação para a cidadania é possível.}

As dificuldades na periferia são enormes. Ser cidadão na periferia e ter garantido o exercício de direitos é difícil. Educar em um universo em que predomina o descrédito do educando e do educador quanto ao poder público, é uma missão árdua. Todavia, a educação é fundamental e ela é a responsável para que se desenvolva o mecanismo que 
faça prevalecer o desenvolvimento de uma sociedade mais justa, que represente a vontade de todos, dirigida para o bem comum e somente esta vontade poderá fazer com que o Estado se faça presente com equipamentos e recursos que possam atender o mínimo de direitos sociais no que tange a trabalho, moradia, educação, saúde e lazer.

A educação para o difícil exercício da cidadania na periferia da grande metrópole, mesmo com a descrença da comunidade nas instituições que representam o poder público e apesar da aparente ausência de ações efetivas do Estado, para garantir a segurança das instituições escolares, é possível e com sucesso. Ela é uma questão de vontade de seus participantes e seu eixo básico deve ir além de ensinar o que ela é e também ensinar como utilizar o direito para fazer o Estado atender o cidadão, quais são os recursos e mecanismos institucionais disponíveis que podem e devem ser utilizados e como utilizá-los, em favor do cidadão.

\section{Educação, expectativa, alerta, realidade e facilitação.}

A educação tem sim, um papel a cumprir, mas apresenta resultados em longo prazo e com certeza não pode ser a única ferramenta de promoção da cidadania. Conforme a maioria dos depoimentos demonstrou, existe uma expectativa de que a instituição escolar além de sua função educativa, acabe concentrando em si a capacidade de oferecer ou resolver o problema da oferta de empregos, dos serviços diversos como os de saúde, jurídicos, sociais e outros também importantes, para a realização ou exercício da cidadania, o que não é verdade.

A visão de que a educação para a cidadania é possível, não pode permitir ou levar a exageros, é preciso esclarecer que está condição quase dramática em que a educação é colocada, sendo vista como uma panacéia para todos os males, não corresponde à realidade. São exageradas as expectativas que se depositam nos resultados de uma educação preparatória para a cidadania e para o trabalho. É preocupante que se espere que 
as alterações das condições de vida da periferia sejam realizadas pela educação, em um curto prazo, esperando dela um retorno imediato.

Na realidade, a educação, que tem uma base física que é a instituição escolar, deve constituir-se em uma estrutura que possa agregar, ser o elo de ligação entre todos e um foco de luz que ilumine o caminho dos que estejam realmente empenhados em buscar um mundo melhor, mais equilibrado e mais justo. Uma trincheira de onde seja possível operar na luta para realizar esta transformação. É importante que se traga para a sala de aula as discussões e informações sobre dados da realidade do cotidiano de sua comunidade, mostrando e propondo se for o caso, o caminho para resolvê-los, levando em consideração não só a comunidade de alunos, mas toda a comunidade onde está inserida. Esta postura com certeza, a leva a ser o mais importante instrumento de promoção da cidadania, mas não a transforma no único e nem pode em momento algum ter está responsabilidade, a educação serve a todos e precisa de todos.

A rede institucional escolar existe, os recursos humanos existem e por mais que se faça sempre existira muito por se fazer e a educação que tanto já faz, precisa fazer um pouco mais, ouvindo todos e através da pratica educativa ser o interlocutor entre o poder público e população, para eliminar o possível déficit de articulação entre práticas e ideais. Ela não é o centro de serviços que grande parte da população periférica pode achar que ela seja, mas pode e deve ser um facilitador de atividades que beneficie toda a população, direcionando as ações educativas no sentido de perceber, identificar e demonstrar o que é, do que precisa e como atender o morador da periferia. 


\section{REFERENCIAS}

ARISTÓTELES. Ética a Nicômaco. Brasília, Universidade de Brasília. 1985

AVRITZER. Leonardo (1994) “Sociedade Civil: Além da Dicotomia Estado Mercado”. In Leonardo Avritzer, org. (1994). Sociedade Civil e Democratização. Belo Horizonte: (1994)

BOBBIO, Norberto. Liberalismo e democracia. São Paulo: Brasiliense, 1988. ,Estado, governo, sociedade: para uma teoria geral da política. 2.ed. Rio de Janeiro: Paz e Terra, 1987 (a).

BOBBIO, Norberto. Liberalismo e democracia. São Paulo: Brasiliense, 1988. ,Estado, governo, sociedade: para uma teoria geral da política. 2.ed. Rio de Janeiro: Paz e Terra, 1987 (a).

La Teoria delle Forme di Governo. Turim: G. Giappichelli Editore. “O Conceito de Sociedade Civil”. Rio de Janeiro: Edições Graal, 1982.

BRESSER-PEREIRA, Luiz Carlos. Estado e Subdesenvolvimento Industrializado. São Paulo: Brasiliense, 1977.

Cidadania e Res Publica: A Emergência dos Direitos Republicanos". Revista de Filosofia Política - Nova Série, vol.1, 1997 (Porto Alegre: Universidade Federal do Rio Grande do Sul, Departamento de Filosofia)..

BRASIL, Constituição (1988). Constituição da República Federativa do Brasil. 10. ed. Brasília. DF: Senado, 1998.

—_ Parâmetros Curriculares Nacionais. Brasília: Secretaria da Educação Média e Tecnológica. 1999.

CARLOS, Ana Fani Alessandri (Org.). CARRERAS, Caries (Org.). A geografia e a 
produção do espaço da metrópole: entre o público e o privado. In: DAMIANI, Amélia Luisa. Urbanização e Mundialização - estudos sobre a metrópole - São Paulo: Contexto, 2005, p.38-48.

, Áreas metropolitanas: espaços colonizados. In: ROBIRA, Rosa Tello. Urbanização e Mundialização - estudos sobre a metrópole - São Paulo: Contexto. 2005. p.9-19.

A reprodução da cidade como "negócio". In: CARLOS, Ana Fani Alessandri. Urbanização e Mundialização - estudos sobre a metrópole - São Paulo: Contexto. 2005. p.29-36.

CASTELLS, Manuel. A questão urbana. Rio de Janeiro: Paz e Terra, 1983.

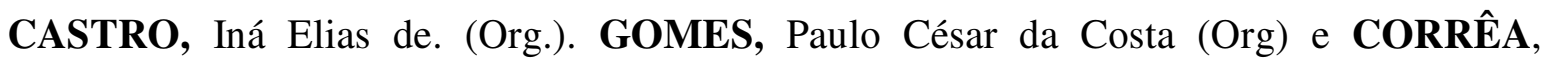
Roberto Lobato (ORG). As drogas e a "questão urbana" no Brasil. A dinâmica Sócio-espacial nas cidades brasileiras sob a influência do tráfico de drogas. In: SOUZA, Marcelo Lopes de. Brasil Questões Atuais da Reorganização do Território. $1^{\circ}$ ed. Rio de Janeiro: BCD. 1996, p. 419-464.

"Miseropolização" e "clima de guerra civil": Sobre o agravamento e as condições de superação da "questão urbana" na metrópole do Rio de Janeiro. In: CASTRO, Iná Elias de, GOMES, Paulo C. da Costa (Org.). Anais do $3^{\circ}$ Simpósio Nacional de Geografia Urbana, Rio de Janeiro 1993 (b)

CHAUI, Marilena. Convite À Filosofia. São Paulo: Ática, 2000.

CINTRA, Antonio Carlos de Araújo e outros. Teoria Geral do Processo. São Paulo: Malheiros 2003, p. 33.

COHEN, Joshua. "Deliberation and democratic legitimacy" (1989). In Bohman, James e Rehg, William (orgs.). Essays on reason and politics: deliberative democracy. Cambridge, MA: The MIT Press, 1997, pp.74-75. 
COTRIN, Gilberto. Fundamentos da Filosofia. 15a ed. São Paulo: Saraiva, 2000.

COULANGES, Fustel. A cidade antiga. São Paulo: Hemus, 1975.

DAHL, Robert A. (1989), Um Prefácio à Teoria Democrática. Tradução de Ruy Jungmann. Rio de Janeiro, Zahar Editor Ltda,1956.

DIMENSTEIN, Gilberto. O cidadão de Papel. São Paulo: Ática, 1994.

ENGELS, Friedrich. A origem da Família, da propriedade privada e do Estado. Rio de Janeiro, Civilização Brasileira, 1975,

ESCOREL, S. Vidas ao léu: trajetórias de exclusão social. Rio de Janeiro: Fiocruz, 1999.

FERNANDES, Florestan. A integração do negro na sociedade de classes. São Paulo, Ática, 1978 (Vol. I e II).

A Revolução Burguesa no Brasil. Ensaio de interpretação sociológica, Rio de Janeiro, Zahar, 1975.

FERREIRA, Nilda Tevês. Cidadania uma questão para a educação. 8 ed. Rio de Janeiro: Nova Fronteira, 1993.

FURTADO, Celso. A nova dependência: dívida externa e monetarismo. Rio de Janeiro: Paz e Terá, 1982.

GIANNOTTI, José Artur. "A nova Teoria da representação". In: Arte e Filosofia. Rio de Janeiro, Funarte 1983.

HABERMAS, Jürgen. 'Três Modelos Normativos de Democracia'. Cadernos da Escola do Legislativo, Belo Horizonte, n. 3., p. 107-121, jan./jun., 1995

- 'Soberania Popular como Procedimento'. Revista Novos Estudos, São Paulo: CEBRAP, n. 26, p. 100-113, março, 199 'Mudança Estrutural da Esfera Pública'. Rio de Janeiro: Tempo Brasileiro 1984.

HARVEY, David. O novo imperialismo. São Paulo: Loyola, 2004.

HEGEL, G.W. F. Fenomelogia do Espírito. 1. ed. São Paulo: Vozes, 1992. 
Princípios de Ia filosofia Del derecho. Buenos Aires: Sudamérica. 1975.

HOBBES, Thomas. Leviatã. 2.ed. São Paulo, Abril Cultural, 1979.

IANNI, Octávio. O colapso do populismo no Brasil. 2 ed. Rio de Janeiro: Civilização Brasileira, 1971.

KABUNDA, Badi M., Las estratégias de supervivência em África y el Tercer Mundo. In: Missiones Extranjeras. Madrid: EME, mayo-agosto de 1996. p. 210-234. "Programas de ajuste estructural y alernativas populares em África. In: Alfoz, Madrid, nº 108, 1994, p. 125-132

KELSEN, Hans. A Democracia. Tradução de Vera Barkow e outros São Paulo: Martins Fontes, 1993. (Ensino Superior). Cf., Kelsen, op. cit., p. 205.

KOWARIC, Lúcio. Trabalho e Vadiagem: A origem do trabalho livre no Brasil. Rio de Janeiro, Paz e Terra, 1994.

KUPSTAS, Márcia (Org.). Um perfil do brasileiro cordial. In: SANTOS, Givanilda

Gomes dos. Identidade Nacional - em debate - São Paulo: Moderna. 1997.p.59-64.

Nem Bósnia nem Belíndia. In: Magnoli, Demétrio. Identidade Nacional -em debate - São Paulo: Moderna, 1977 -p. 107-112

O Brasil em construção. In: SAMPAIO, Plínio Arruda Identidade Nacional - em debate - São Paulo: Moderna, 1997. p. 127- 156.

LANZONI, Augusto. Iniciação às ideologia políticas. 5 ed. São Paulo: Icone, 1998.

LEFORT, C. Pensando o Político. São Paulo: Paz e Terra, 1986.

LOCKE, John. Ensaio acerca do entendimento humano. 2.ed. São Paulo: Abril Cultural, 1978.

LOSURDO, Domenico. Hegel, Marx e a Tradição Liberal: Liberdade, Igualdade, Estado. São Paulo- Unesp, 1988.

LOWY, Michael. Ideologias e ciência social. São Paulo, Cortez,1985. 
MARSLHALL, T.H. Cidadania, classe social e status. Rio de Janeiro: Zahar, 1967.

MINAYO, M.C. (Org). Pesquisa social - Teoria, Método e Criatividade. Rio de Janeiro: Vozes, 1994.

MOCELLIN, Renato. As reações armadas ao regime de 64. São Paulo: Brasil, 1989.

MONDAINI, Marcos. O Socialismo Liberal de Norberto Bobio. - Especial para Gramsci e o Brasil - pagina da Internet, acesso: em 28 jan. 2006. Brasil Textos/Marx\&Marxismo - Disponível em http://www.artnet.com. br/grarnsci/arquiv1 99. htm-

NAPOLITANO, Marcos. O regime militar brasileiro. São Paulo: Atual, 1998.

OLIVEIRA, Pérsio Santo de.Introdução à Sociologia. São Paulo: Àtica, 1997.

PAES, Maria Helena Simões. Em Nome da Segurança Nacional. $5^{\circ}$ ed. São Paulo: Atual. 1995.

PATEMAN, Carole. Participação e teoria democrática (Participation and democratie theory). Trad. Luiz Paulo Rouanet. Rio de Janeiro: Paz e Terra, 1992, 161 p.

PEDROSO, Regina Célia. Violência e cidadania no Brasil. São Paulo: Ática, 1999.

PINHEIRO, Paulo Sérgio. A estratégia das Ilusões (a revolução mundial e o Brasil-19221935). São Paulo: Companhia das Letras, 1993.

PREZEWORSKI, Adam. Economic Reforms in New Democracies. Cambridge University Press, 1993

RIBEIRO, Darcy. Aos trancos e barrancos: como o Brasil deu no que deu. 3a.ed. Rio de Janeiro: Guanabara Dois, 1985.

ROSA, António Vitor. Agricultura e Meio Ambiente. São Paulo: Atual, 1998.

SADER, Eder. Quando novos personagens entram em cena - Experiências, Falas e Lutas dos Trabalhadores da Grande São Paulo (1970-80). São Paulo: Paz e Terra, 1988.

SARTORI, Giovani. A Teoria da Democracia Revisitada. São Paulo: Ática: 1994. 
SCHUMPETER, Joseph A. Capitalism, socialism and democracy. Nova York: Harper \& Brother, 1942.

SCHNEIDER, Bertrand. La revolucion de los Desheredados. Madrid: Alambra, 1986.

SOUZA, Jessé. A construção social da subcidadania: Para uma sociologia política da modernidade periférica. Belo Horizonte-Rio de Janeiro: Ed. UFMG e Iuperj, 2003.

THOMPSON, Paul. A voz do passado - Historia Oral. São Paulo: Paz e Terra, 2002.

TOMAZI, Nelson Dácio. Sociologia da educação. São Paulo: Atual, 1997.

TOURAINE, Alain. O que é a democracia? Trad. Guilherme João de Freitas. Petrópolis: Vozes.

TIRIBA, Lia. Economia Popular e Cultura do Trabalho: Pedagogias de produção associada. Ijuí - RS, UNIJUI. 2001.

VALIM, Ana. Migrações: Da perda da terra à Exclusão Social. 5 ed. - São Paulo, Atual, 1998. 
6. ANEXO I - ENTREVISTAS REALIZADAS NA ESCOLA PÚBLICA

1) Professor Dalbino de Oliveira - Coordenador.

2) Professora Cleidevânia Gomes dos Santos.

3) Professora Rita de Cássia

4) Professora Sonia Lima

5) Aluno Isac Gima.

6) Aluno Diego Vieira da Silva.

7) Aluna Elisângela 
Professor Dalbino de Oliveira

Coordenador Pedagógico

Professor Habilitado inicialmente em Pedagogia, Administração Escolar e posteriormente em Geografia Plena e Curta em História, com pós-graduação, LatoSenso, em Geografia. Atua em educação há 16 anos. Foi inicialmente professor, chegou a ser Vice-Diretor e há seis anos é Coordenador Pedagógico.

1) Quantos funcionários o colégio tem?

R: Aproximadamente 65 professores e 15 funcionários administrativos e de suporte escolar, havendo funcionários terceirizados.

2) Existem Instalações de suporte pedagógico:

R: Sim, 1 Biblioteca com sala de leitura e com 3.500 volumes.

3) Tem bibliotecária?

R: Nós temos uma professora readaptada do estado que cuida da biblioteca, o que atende as necessidades dos alunos.

4) Existem outros equipamentos de suporte pedagógico?

R: Nós temos também um laboratório que não está sendo usado, agora é sala de vídeos. Temos a sala de informática com 10 computadores né, que os alunos estão usando na medida do possível, que quando os professores elaboram projetos levam eles até lá, então está sendo usado, então creio que é isto que temos como suporte pedagógico.

5) Gostaria que o senhor falasse das salas de aulas, quantas são e quantas são utilizadas?

R: Temos 14 salas divididas em dois pavilhões com 7 salas cada um. As salas são utilizadas nos períodos manhã tarde e noite, nós temos uma média de 1100 alunos.

6) Conforme o Plano Escolar como é caracterizada a clientela? 
R: A clientela aqui, desde quando eu comecei a lecionar aqui em 1992, eu tenho notado que ela continua sendo muito carente, né, muitos problemas sociais, famílias desestruturadas. Tudo isto afeta nosso trabalho, sempre tivemos dificuldades, mas o que vemos em demasia mesmo são os problemas familiares. Problemas econômicos, muitos pais desempregados, quando chamamos os pais para conversar, eles desabafam com a gente. Brigam pela posse dos filhos, tentam vir até aqui tirar o filho da escola, sem mandado judicial. Temos muitos pais separados o que acaba afetando o lado psicológico dos nossos alunos.

7) Dentro da proposta pedagógica o que vocês estabeleceram como objetivo principal?

R: O nosso objetivo aqui na escola, desde quando eu assumi na coordenação, a nossa proposta foi a integração, entre professores, direção e comunidade, porque na verdade estamos trabalhando a questão da cidadania. Temos que trabalhar juntos.

8) Quais são os principais problemas enfrentados pela escola?

R: Os principais problemas, como havíamos falado são os problemas familiares que refletem muito na cabeça do nosso aluno, mas o maior problema é ausência dos pais na escola. Muitas vezes temos que chamar uma, duas ou três vezes o pai, para tratar até de problemas de indisciplina. Eles demoram em vir na escola e nós temos que mandar alguém ir lá buscar.

9) A rotina maior de problemas aqui na escola o senhor poderia dizer qual é?

R: O maior problemas, não é que os alunos sejam agressivos, que tragam armas, isto não, mas é o desrespeito para com os professores. Os alunos às vezes não toleram, o professor quer ensinar, falar alguma coisa e os alunos não aceitam e ai acaba tendo que a coordenação intervir nestas questões disciplinares da escola.

10)Qual o suporte que a escola tem para desenvolver ações para a cidadania em 
relação à Secretaria de Estado e o que ela faz como ação isolada, dela, escola?

$\mathrm{R}$ : Na verdade o governo tem até tentado investir na escola, criando alguns projetos para que o aluno possa se integrar mais na escola, a questão no projeto água a fonte da vida. A questão que ele colocou também na orientação voltada para a saúde, de problemas graves da saúde e a escola em si está trabalhando muito a questão do meio ambiente, né, a questão cultural; levando ao teatro... estamos tentando fazer nossa parte nesta questão.

11) A escola tem dado o suporte necessário para que os alunos possam exercer a cidadania e a democracia dentro da comunidade em que estão vivendo?

R: A escola em si ela luta para dar suporte para a comunidade e para os alunos, mas os recursos têm que vir de fora, né, e às vezes nem sempre vem, os recursos que nós temos são de acordo com o número de alunos que temos, se a escola não tem muitos alunos não vem muito dinheiro, mas a escola tem se esmerado para dar suporte aos alunos.

12) O exercício da cidadania na periferia é algo que o ser vê como possível de ser desenvolvido?

R: Tudo é possível crer, mas não está fácil não, porque encontramos muitas barreiras, até retomando o que já falamos se a família não ajudar a escola, a escola fica com as mãos atadas, nós professores, coordenadores, diretores estamos tentando achar um meio para mudar um pouco o quadro de nossos alunos e até quem sabe da família. Não podemos ignorar a formação que os pais tiveram. A maior parte dos pais dos nossos alunos cresceram e formaram-se no período ditatorial, o que implica em uma formação complicada na questão de democracia, que para a maioria deles limita-se a votar e ser votado, se não existe uma clara compreensão da democracia a prática da cidadania fica prejudicada. 
13) A questão dos direitos sociais como a escola trabalha?

R: Pela lei sabemos que não podemos sonegar informações, temos que deixar nossos alunos cientes dos direitos que eles têm, embora muitos diretores ficam preocupados em abrir muito, porque conforme ensinamos há cobranças, nós tentamos deixar nossos alunos cientes de seus direitos e deveres como cidadão.

14) Na medida em que se educa espera-se um retorno, qual sua avaliação em relação aos alunos, no que tange ao exercício da cidadania em relação ao mundo em que nós vivemos?

$\mathrm{R}$ : Na verdade quando se fala em educação a gente nunca espera resultado em curto prazo, mas sim a médio e longo prazo. O que eu vejo não nestes alunos que estão aqui, mas nos alunos que já saíram que eu encontro, até encontro nas escolas, que vem aqui e falam que estão fazendo Faculdade, eu vejo não todos, mas uma boa parte dos que conversam com a gente, que falam valeu aquela aula; valeu aquela explicação, ele vem agradecer, então eu vejo com bons olhos, eu creio que nossa fala não está sendo em vão, mas a evolução é lenta.

15) O quadro de professores de forma geral, deve ter comprado a idéia de formar o aluno para a cidadania. Eles encontram muitas dificuldades para desenvolver esta atividade de educação para a cidadania ou eles encontram o apoio necessário por parte do governo?

R: Não. Não encontra. A educação é muito difícil a pessoa tem que estar empenhada, pesquisar e saber, realmente muitas coisas se perdem pela falta de tempo, porque o professor começa a trabalhar de manhã e vai parar onze horas da noite em busca de recursos financeiros, não tem como preparar uma aula ou mesmo se preparar melhor. E aí o que acontece, o que está acontecendo é que acaba tendo capacitação do governo tal e ele não tendo tempo suficiente, o que eu vejo é que o professor, 
não sei se estou sendo grosseiro, mas o professor é marionete. Ele faz aquilo do momento, mas não da para ele reavaliar o que ele está fazendo em sala de aula e no seu dia a dia e na verdade o professor também tem sua família que tem que cuidar e que muitas vezes deixa até aquém do que ela precisa. Mas o governo está tentando fazer o papel dele e então fica uma coisa assim o aluno finge que aprende e o professor finge que ensina e nós temos uma democracia pela metade.

16) A capacitação do professor, de forma geral, tem resolvido os problemas específicos que tem surgido no Estado, como a violência, por exemplo? $\mathrm{O}$ professor está sendo capacitado para lidar com está violência, com está indisciplina, com os problemas sociais decorrentes do desemprego, desta questão social que acaba afetando a escola, a capacitação tem sido eficaz para isto?

R: Na verdade quando nós vamos a cursos de capacitação eles mostram uma realidade que muitas vezes não é a realidade que nós gostaríamos de ver, mostram uma outra realidade. Pegam uma realidade lá da zona sul que nada tem a ver com a da zona leste, então fica só nos paliativos. Fala-se muito, mas no papel é uma coisa e na prática é outra é a questão da teoria versus prática, muito se fala e pouco se faz.

17) Seria o caso de quem faz ou planeja capacitação passar por uma sala de aula da periferia para saber realmente o que é necessário, seria este o caso?

R: É verdade eu creio que é isto ai sim, nós temos muitos tecnocratas que ditam as regras e quando você vai ver a biografia dele e o dia a dia dele é uma outra realidade daqui da periferia.

18) Valendo-se do seu tempo de magistério, 16 anos, o aluno de ontem é diferente do aluno de hoje ou é igual e quais seriam as diferenças caso elas existam?

R: Na minha opinião, analisando assim, a grosso modo, os alunos que eu lecionei há 
dez anos atrás tinham mais expectativas, vivia em um mundo diferente, em um cenário diferente e lógico com mais oportunidades, ele tinha uma outra noção, buscava mais, hoje em dia os alunos estão muito acomodados. Eu não sei se é falta de perspectiva de alguma coisa, perderam um pouco a visão do que querem, quem sabe um pouco é porque o governo não ajuda e minimizou bastante a questão do emprego, está tudo terceirizado. Pode ser desânimo e falta de perspectiva. 
Professora Cleidevânia Gomes dos Santos

Habilitada em Letras e leciona ha três anos.

1) Professora qual o seu conceito de cidadania e democracia?

R: São os valores que nós adquirimos e nós exercemos na sociedade, na vida no dia a dia e também o conceito histórico de que democracia é o povo no poder.

2) Como a senhora passa ou tenta passar estes valores para seus alunos?

R: Nós tentamos passar na vivência em sala de aula, um com o outro, o princípio da igualdade, mas é difícil o aluno questiona sempre, afirmando que existe diferença de direitos para os que exercem o poder e para os ricos, falam em arrogância da autoridade, quando, por exemplo, um juiz contraria propositalmente o sentimento do Brasil inteiro e solta um criminoso hediondo, que a imprensa, a televisão, mostra diariamente que ele é monstruoso, mas o juiz solta e todo mundo sabe que a mesma lei que ele usa pode manter o bandido preso, acham que ele faz isto para humilhar a sociedade, que em sua maioria é formada por pobres e também quando todo muito critica mas as autoridades resolvem aumentar seus enormes salários, contra a vontade da nação.

3) A senhora acha que é possível educar para o exercício lúcido e consciente da cidadania na periferia?

R: Tentar a gente tenta, mas é difícil, é muito difícil para ele ai fora. Exercer os direitos de cidadania. É muito difícil para ele compreender que o poder, que todos os poderes em última instância pertence a ele. Ele não acredita e na prática eu vejo que não é assim e acabo também não acreditando.

4) Quais seriam as dificuldades?

R: Arrumar seu primeiro emprego, sofre discriminação por morar na periferia, que é o primeiro obstáculo na vida dele, ele parece não ser um cidadão igual aos outros, 
existem cidadãos que parecem estar acima dele.

5) A senhora acha que existe uma política efetiva ou ação de governo na educação para que seja desenvolvida esta cidadania e também na comunidade como um todo para que o aluno possa exercer sua cidadania?

$\mathrm{R}$ : O governo deixa muito a desejar em investimento no jovem da periferia, pos isto que muitas vezes ele fica descrente até mesmo dentro da escola.

6) Neste quadro de descrença em que muitas vezes o professor tem que trabalhar a senhora acha que o trabalho traz resultados positivos?

R: Se for um trabalho em conjunto entre professores, direção e a família dos alunos, traz benefícios.

7) A escola tem feito este trabalho?

R: A escola aqui tem feito um bom trabalho sim, tem desenvolvido projetos culturais, como ida ao teatro, por exemplo, tentando amenizar os problemas dos alunos.

8) Como a senhora vê a questão dos direitos sociais aqui na periferia em relação aos seus alunos?

R: Olha é muito difícil na periferia, com relação à saúde e em relação aos postos de saúde, eles falam que se tiver que marcar uma consulta tem que esperar meses para serem atendidos, se tiver um problema na hora, ele não será resolvido. $\mathrm{Na}$ escola a gente tenta passar o que a gente pode fazer, onde recorrer, mas é pouco, muito pouco e muito difícil para o jovem. Muitas vezes eles se sentem descrentes de tudo não querem saber mais de nada, não tem uma perspectiva de vida, a grande verdade é que o aluno não tem perspectiva de vida.

9) Como você acha que este aparente abandono do jovem na periferia pode ser resolvido?

$\mathrm{R}$ : Eu acho que é mais culpa do governo mesmo que não investe na periferia com 
relação a esporte, a educação, em suma fazer um trabalho realmente social que dê certo. Não passar uma coisa que não existe, passa coisas na televisão que não existe na escola e nem na sala de aula. No dia a dia da convivência com o aluno não há o que eles mostram. Muitas vezes a gente tem dificuldade de desenvolver um trabalho na escola por falta de material e dinheiro e investimento. Muitas vezes nós professores somos convidados a ir para oficinas pedagógicas e ficamos ouvindo aqueles professores que já saíram da sala de aula, querer passar uma realidade que por muitas vezes só existem mesmo em escolas particulares, que são alunos aplicados, materiais bons para se trabalhar em sala de aula. Aquilo dali existe realmente mais muitas vezes num vídeo e muitas vezes em escolas particulares porque em escolas mesmo do governo é tudo uma escassez. Muitas vezes pra nós professores estarmos elaborando uma aula diferente, nós temos que estar tirando do nosso próprio salário pra dar uma aula diferente para os nossos alunos. 


\section{Professora Rita de Cássia.}

Habilitação de Ensino Médio para o Magistério e tem 18 anos de magistério, não concluiu a Habilitação Plena em Educação Artística, leciona na $3^{\circ}$ série do ciclo I.

1) Qual o seu conceito de cidadania?

R: O meu conceito de cidadania, acho, que é tudo assim, como eu posso estar explicando, ser um bom cidadão, de que forma? Ter um objetivo, ter participação, poder criar algo que a coisa toda ta tão complicada tão difícil. Elaborar projetos está difícil. Quando se fala em cidadania, aqui, eles imaginam o que? Povo, pessoas e não conceitos a serem trabalhados com as pessoas, para que se tornem ações práticas no dia a dia.

2) Dá para elaborar um perfil do aluno de ontem e do aluno de hoje, eles são diferentes?

R: É diferente, muito diferente, não que eu tenha trabalhado tanto com o aluno de ontem, mas eu tenho dezoito anos de magistério e deu para você perceber que eu tenho uma idéia da diferença. O aluno de ontem tinha objetivo, tinha uma meta, sabia o que ele queria, tinha um sonho, o aluno de hoje não. O aluno vem para a escola se concentra mais em assuntos que só para ele tem importância, tem uma certa importância, mas para nós não, ou seja, o aluno de hoje ele entra em uma sala de aula pensando em que? Que se ele vir para a escola e cumprir cinco horas, ele está quite com a escola. O aluno de ontem preocupava-se com o que o professor passava, com o nível do conteúdo do que o professor ministrava, com pesquisas, com perguntas, eram alunos mais questionadores, hoje não, o aluno tem medo de questionar, tem medo muitas vezes de colocar o que ele está pensando e se você tentar se envolver muito com a situação, até mesmo a comunidade te questiona. Se eu abranger um assunto maior da comunidade mesmo, no caso a 
comunidade me questiona, o aluno e a comunidade de ontem não, o aluno e a comunidade hoje têm muito medo.

3) Que você acha que aconteceu para esta mudança de perfil?

R: Mudou tudo. Eu acho que o sistema, que o próprio sistema estadual, mudou, mudou muito. O Estado quer o aluno dentro da escola, o importante é ter a clientela dentro da escola, está certo, quanto mais aluno melhor. O aluno está visando que quanto mais ele vir e cumprir sua permanência na escola está bom, ele não tem objetivo ou meta de aprender e adquirir conhecimentos, porque ele acha que para sobreviver neste meio não é do conhecimento escolar que ele precisa.

4) Existe hoje um maior ou menor interesse do Estado, através de ações positivas, sérias e corretas para preparar melhor o cidadão ou não?

R: Eu não coloco assim que o governo tenha culpa, tudo acaba em cima do governo. O governo tem o que? Ele tem a escola, tem os professores, bons professores, o que está acontecendo? A própria formação em casa, os pais, os que estão vindo agora, estão nascendo agora, estão vindo de famílias sem perspectivas, sem objetivo, sem meta. Todo o encargo da educação eu não coloco todo no governo não ou na escola. A sociedade também tem responsabilidade e ela está tendo menos participação e a ação não pode ser apenas no âmbito da escola, são necessários outros mecanismos sociais.

5) Qual o papel da escola na formação da cidadania, você acha que ela está cumprindo o seu papel neste aspecto?

R: Ela tenta, tenta, mas acho que ainda falta muita coisa, ela ensina, mas fica impotente quando tem que ajudar o aluno a procurar seus direitos e perdida com as políticas do governo em relação, por exemplo, à segurança. A polícia pensa que sabe o que faz, mas não sabe, porque ela nunca está no lugar que precisa, então o 
especialista que coordena as ações ou trabalho da polícia, pensa que sabe, mas não sabe, o cidadão é que sabe, em sua comunidade, onde a polícia devia estar e como ela devia agir e não quem comanda a polícia. Isto é só um exemplo, mas quase todos as instituições ou trabalhos que o governo oferece, são assim, eles não sabem o que estão fazendo. Agora, o governo oferece e tentar ele tenta, só não sabe fazer o certo.

6) Você professora, consegue atuar na comunidade sendo respeitada como cidadã?

$\mathrm{R}$ : Eu consigo, consigo sim, mas é uma luta e a gente acaba sendo visto como encrenqueira, só por querer as coisas certas.

7) Então as relações de cidadania na periferia são boas, desde que o próprio cidadão procure fazer se respeitar?

R:Em vista de algumas escolas que eu já trabalhei, aqui na nesta escola sim, as relações são boas, mas você tem que se empenhar muito.

8) Não, não, não na escola, eu digo na periferia, na comunidade como um todo.

R: Não, não, na periferia como um todo não, elas são ruins, a princípio ninguém sabe quem é o outro, ou quem você é e acabam dando um tratamento que te subestima, você tem que lutar para ser respeitado.

9) O que você acha que seria necessário como ação para que houvesse respeito à cidadania e à democracia?

R: Difícil, me dê um exemplo de respeito e qual objetivo a ser atingido? Exemplo, ninguém achar que você é ignorante, ninguém tentar te enrolar, porque é comum achar que por ser da periferia todo mundo é bobo. Qual o objetivo para quem não te respeita, te respeitar? A questão é também de educação.

10) Eu falo das relações cotidianas de transações comerciais, saúde, educação, moradia, etc. 
R: É bem dividido bem mesclado, existem coisas que funcionam e outras que não funcionam, alguns respeitam e outros não. Não, no geral, não existe respeito à cidadania.

11) O que seria necessário para mudar o quadro?

R: Conscientizar, principalmente a partir da educação, é preciso dar a consciência do que é realmente a cidadania.

12) Você acha que o cidadão dos jardins e o da periferia são vistos da mesma forma pelo governo?

R: Não, imagina, de forma alguma, bem diferente, um exemplo até bobo, nos jardins você vê pessoas passando correndo, fazendo exercícios e é normal, aqui ver alguém correndo ou roubou ou está sendo assaltado! Tudo que você olha e vê, você já olha com medo, a violência já gerou o medo, até passear saindo daqui e indo para os jardins você se sente mais protegido lá e aqui não, aqui é só medo.

13) O cidadão está acuado?

Tem o meu caso, eu já me assustei, eu trabalhei em outros ambientes, em outras escolas, eu me assustei com o local, com as pessoas, com o que falavam. Eu trabalhava assustada, tinha medo dos alunos e comecei a ficar acuada. Como eu iria tratar estas crianças, como tratar os pais das crianças? Isso não é bom, trabalhar com medo e acuada por pais e alunos, você acaba não realizando o seu trabalho, não passando o que você quer passar para a criança, você tem medo, como vou fazer?

14)Você superou isto e como superou?

R: Superei depois de cinco anos. Eu procurei falar com eles e demonstrar que eu queria passar coisas úteis e não coisas que pudessem prejudicá-las, que eu queria o bem de todos. Comecei a passar para eles uma visão do que é a droga, como é o 
mundo lá fora. Muitas vezes trabalhei, ou na maioria das vezes trabalhei com crianças filhas de pais separados. As crianças não conseguiam entender os motivos da separação, aí vinham os pais e falavam "olha professora meu filho hoje não está bem hoje, porque nós estamos separados" e eu passei a conversar e dizer: isto não justifica, os pais podem estar separados entre si, mas não podem separar-se dos filhos, a separação não implica que os pais não possam ficar juntos na educação dos filhos. Antes eu tinha medo de fazer isto, fui perdendo o medo e fazendo o meu trabalho. Já tive muito medo, já trabalhei com muito medo, agora para mim é fácil trabalhar, fazer isto.

15)Você freqüentou algum curso, fez capacitação para superar isto?

$\mathrm{R}$ : Freqüentei e teve coisas que me tocaram muito. Eu percebi que os alunos precisavam de mim, eu não podia ficar com medo, eles precisavam de mim e então comecei a fazer o meu trabalho, até então eu não fazia e os alunos percebem o seu medo e exploravam isto, resolvi não ficar mais acuada e trabalhar para quem precisava.

16) Você acha que aqui na escola trabalha-se bem esta relação aluno-comunidadecidadania-democracia?

R: Trabalha sim. Por ser uma escola que atende ciclo I, ciclo II e ensino médio, eu acho que sim, não é a primeira escola que eu trabalho que atende estas modalidades. Aqui eu não vejo quase problemas tão drásticos como em outras, os professores conversam muito com os alunos, os alunos conversam muito com os professores, direção e coordenação. Você vê assim uma amizade, uma cumplicidade entre os pais, eventos, eles participam muito. É, são pessoas humildes né, com uma condição financeira bem baixa, a realidade é esta, mas são pessoas que tentam ajudar e fazer até o que não podem. Mas é uma escola que dá 
para você ver que têm interação entre professores, coordenadores, família e comunidade. A escola trabalha, agora só o tempo vai mostrar o resultado do trabalho.

17) $\mathrm{O}$ que você acha que seria necessário para resolver os problemas desta comunidade?

R: É tão complicado tão difícil da gente dar soluções, mas acredito que é preciso mais interação, mais diálogo que permita melhor organização, o governo deveria estar mais perto e apoiar a escola com recursos financeiros no que ela acha que pode e deve fazer.

18) Em termos de equipamentos e materiais didáticos, você acha que a escola é bem atendida?

R: Ela é sim, tem suas falhas como todas as escolas têm. Tem acervo, temos livros, tem material didático, tudo que a criança precisa ela tem. Pode estar pesquisando, temos uma sala de informática que não é fechada, ela é aberta o aluno pode ter acesso, eu acho que a escola cumpre seu papel.

19)Você colocaria seu filho aqui?

R: Sim, eu colocaria, colocaria sim, ele está no SESI, mas eu o colocaria aqui tranqüilamente. 


\section{Professora Sonia Lima}

Licenciada em História pela Unicastelo.

Leciona na rede pública e na instituição privada que pesquisamos, desde 1998. Ministra aulas em todas as séries do Ensino Fundamental e Médio, nas seguintes disciplinas: História, Geografia, Filosofia e Sociologia.

1) Como você vê a ação da escola pública na formação da cidadania e da democracia? E como você vê a ação da escola particular?

R: Na minha visão o tema cidadania é muito complexo, pois nas escolas do Estado trata a cidadania com leituras de livros. Exemplo, o que é capoeira, cito este tema, pois estive em contacto direto, mas obriga-se o aluno a ler, faz-se avaliação e o assunto termina por ai, ou seja como a cidadania pode ser discutida e resumida em um livro de capoeira? Quanto as escolas particulares, principalmente as localizadas na periferia e eu trabalhei em diversas, salvo raras exceções, também não trabalham a cidadania e nem a democracia, ficando também resumidas a leituras de livros. A cidadania que eu tento passar para os alunos através de livros torna-se algo deprimente. Tanto a escola pública como a particular não vê o aluno como cidadão, para o Estado ele é apenas um número e para a particular cifra, pois quando o mesmo não cumpre com o pagamento ele é podado de várias atividades, compreendo que a escola é uma prestadora de serviços. Mas o que é cidadania? A escola só trata enquanto cidadão aquele aluno que não dá trabalho de forma alguma.

3) Existe interesse do Estado, com ações positivas, sérias e corretas em efetivamente preparar o cidadão? Você sabe que sempre esteve colocado na fala oficial o objetivo de Educação como formação da cidadania, percebeu mudanças na relação Educação e Cidadania após a publicação dos parâmetros curriculares nacionais, no 
pós 1996? Existe interesse do Estado, com ações positivas, sérias e corretas em efetivamente preparar o cidadão?

R: Quanto à implantação dos parâmetros curriculares nacionais, é visto apenas na conduta do aluno, onde o mesmo acredita que a cidadania que ele tem por direito é ir apenas na escola, onde ele pode agredir aos colegas e professores e os agredidos compreender que ele tem uma família desestruturada e relevar, onde não se pode cobrar nada do mesmo, isso é cidadania? Ou é isso que o governo quer que pensemos que seja cidadania?

4)Existem alguns colegas que acham que hoje realmente está muito melhor que ontem e neste ritmo amanhã deverá estar melhor do que hoje? Você vê assim?

R: Quando alguns colegas dizem que hoje está melhor, faço uma reflexão sobre o assunto. Que conceito de cidadania existia nas décadas anteriores onde não podíamos expor nossas vontades, pois éramos reprimidos, então não havia cidadania e nem democracia. Hoje não vejo nenhuma transformação, porque o cidadão continua procurando o que é ser cidadão e não participando efetivamente da condução dos destinos da naca, ele está totalmente alijado do poder, que teoricamente é exercido em seu nome. Chamamos de cidadania os nossos deveres e direitos, mas não sabemos quando começa ou termina, onde nas escolas sempre haverá a exclusão, tanto na particular quanto na pública. A opinião é geral a tendência não é piorar, mas estagnar. Porque os órgãos competentes também não sabem por em prática o que é cidadania e menos ainda os mecanismos da democracia.

5) Em uma periferia como esta você vê carência de equipamentos sociais, e ou percebe alguma ação concreta do Estado para alterar o padrão e a qualidade de vida desta população, ou percebe que tudo caminha bem e que todos realmente estão bem 
atendidos? Ou acha que alguma coisa está errada e como deve ser feito para melhorar?

R: Nós aqui na periferia não temos equipamentos sociais, ou seja, os hospitais, postos de saúde, escolas públicas são tão carentes quanto os cidadãos que os freqüentam, onde os políticos lembram-se desses cidadãos penas na época das eleições, então a democracia é lembrada e decantada, sendo essa a visão de democracia que tentam impor para o povo, simplesmente votar. Nos postos e hospitais faltam medicamentos, aparelhos para exames e as próprias escolas não têm materiais didáticos para desenvolver atividades necessárias. Pode ser sonho, mas se a comunidade não participar ativamente buscando junto com setores citados acima soluções, o governo fica alheio aos problemas na periferia.

6) Uma vez que cidadania implica em direitos sociais, como você analisa está questão na periferia? Vai bem ou vai mal em quais seguimentos?

R: A cidadania compreendida como direitos sociais na periferia não existe, quando o cidadão precisa de algum órgão público é tratado com descaso, mas o próprio cidadão que o atende esquece que naquele momento está segundo o seu senso comum em melhor condição, mas quando fora do seu setor no bairro, nas ruas, nas escolas públicas, nos hospitais, etc. ele é tratado da mesma forma com desprezo. Quando ele recorre à justiça o desprezo é o mesmo. Acredito que para começarmos a entender o que é cidadania deveria partir do próprio ser em ver o outro igual que o ser só precisa ser compreendido e também compreender, mas esse trabalho talvez se consiga em longo prazo. Algumas propostas pedagógicas têm palavras bonitas, mas não funcionam se o ser não demonstrar interesse.

7) Você acha possível educar para o exercício da cidadania com resultados positivos?

R: Acredito que conscientizar em nome da cidadania é um trabalho árduo, que talvez 
possamos ver alguns resultados apenas há alguns anos, mas será um resultado fragmentado pois a sociedade está muito confusa, essa redemocratização do Brasil veio para complicar e não para conscientizar, porque, ora, nada é permitido e de repente tudo é natural.

8) O que você faria como sugestão para se atender este objetivo?

R: Como a escola é formadora de cidadão, isto analisando pelo lado pedagógico, então ela deveria iniciar eu trabalharia o uso do uniforme, respeito dos inspetores, professores, enfim com todos os componentes da escola, mas também faria a mesma conscientização com os funcionários, porque não adianta cobrar do aluno se os demais continuaram a tratá-los de forma indiferente, e a partir daí levar isso para o dia a dia do aluno, isso até parece meio utópico, mas se não tiver uma iniciativa e mostrar resultados nada adiantaria, mas a escola não pode esquecer e aqueles que a compõe que todo ano há uma realidade diferente e partindo novamente do princípio com ajuda dos demais que já estavam na escola.

9) Você sente retorno em uma ação sistemática da educação voltada para a cidadania e prática democrática?

R: Não ocorre uma educação sistemática da escola, porque a escola nunca é a mesma, ou seja, professores principalmente todo ano mudam-se os professores, todo ano as aulas vão para atribuição nas Diretorias Regionais de Ensino e mudam-se os professores.

10) Você acha possível o desenvolvimento integral do cidadão sem consciência cidadã? Fora o processo sistemático da educação, existe apoio do Estado para o desenvolvimento de uma consciência cidadã? Quais outras instituições governamentais poderiam dar uma contribuição positiva e atualmente quais ajudam e quais atrapalham? 
R: Eu não vou citar uma instituição e sim um Código O ECA. Ele precisa ser revisto, muito do ali colocado não condiz com a realidade, mas as pessoas o levam ao pé da letra quando o mesmo é para beneficiá-los, o mesmo que o usa em sua defesa, continua a não respeitar a lei do seu condomínio, da escola, etc. Para punir a escola o ECA é maravilhoso.

11) Isto significa que ele atrapalha?

R: Não, apenas que se ele não for revisto urgentemente será apenas um instrumento de proteção ou de estímulo ao crime. 


\section{Aluno Isac Gima}

1) Qual seu nome completo? Você sempre estudou em escola pública? Que série você está cursando hoje?

R: Meu nome é Isac Azevedo Gima eu sempre cursei em escola pública e estou no $3^{\circ}$ ano do Aquilino Ribeiro.

2) Qual a sua idade?

R: Eu tenho 18 anos.

3) Isac, qual é o seu conceito de cidadania e democracia?

R: O conceito de cidadania e de democracia é que todo tem que ter o mesmo direito, né, tem que, gente cidadão, né? Meio de transporte e estudo, saúde tem que como que fala? Calma aí! A palavra sumiu da cabeça! Tem os direito, né, do cidadão!

4) Isac você consegue atuar como cidadão e ser respeitado como cidadão no seu diaa-dia?

R: Atuar como cidadão e ser respeitado? Ser respeitado não, porque tem muita discriminação, né cara, não só por mim, mas por varias outras pessoas tipo racismo, aqui você é visto como inferior, tem muita coisa e atuar! Atuar acho que sim, mas ser respeitado, muita discriminação tem, fica difícil e os direitos da gente acabam não sendo respeitados.

5) Se você e de forma geral o cidadão aqui na periferia não é respeitado, então os direitos de cidadão dele não estão valendo. O que você acha necessário para que se respeite a cidadania?

R: Primeiro tem que se cumprir as leis, né. Tem que ter mais respeito da população, tem que se conscientizar do que está fazendo, não tem que ser tudo amontoado, tem que se saber o que se está fazendo, tem que ter uns políticos bons "cara", leis boas, tem que saber no que mexer, se tem que lutar, saber quem colocar lá na 
presidência pra governar isso aqui direito, ta... nada mudou, ta tudo no mesmo canto e vai só piorando, piorando, piorando, ta bom só para bandido, que ta à vontade.

6) Qual você acha que é o papel hoje da escola e qual deveria ser o papel da escola na formação para a cidadania e democracia?

R: O papel da escola é formar os alunos para a cidadania, saber o que é certo o que é errado. Formar certo que é errado assim nos seus direitos, né, porque formar certo e errado também é papel do pai, o pai também só não colocou o filho no mundo, tem que saber ensinar ele, educar e dar educação o resto quem ajuda mais assim também é a escola, porque a gente fica um bom tempo dos nossos dias na escola, tal, e a escola também tem que dar uma ajuda pra gente.

7) Você falou em respeito e desrespeito, e eu vou te fazer uma pergunta: será que lá nos Jardins a cidadania é vista pelo governo da mesma forma como é vista aqui na periferia?

R: Não, como ela é vista lá nos jardins você fala? Não a situação de lá é bem melhor do que a daqui, lá você não é visto como inferior.

8) Mas a visão do governo, o governo não vê do mesmo jeito?

$\mathrm{R}$ : Eu acho que não porque lá nos jardins quando você fala assim, onde tem as pessoas com mais, o capital mais elevado, e aqui...tem um pouco mais de lixão pra gente, vai cada vez mais se amontoando se transformando em favela.

9) E qual a diferença lá?

R: A diferença lá é porque os policiais vão tratar eles de uma outra maneira, tipo aqui... é, na periferia, aqui eles já pegam o pessoal subindo na escola já te enquadra e deixa um bom tempo lá enquadrado, lá nos jardins não, os policiais já chegam perguntam, tem outro tipo de lidar com as pessoas de lá com as daqui. 
10) Isac você quer acrescentar alguma coisa em relação à escola em que você estuda e o trabalho que ela desenvolve para o exercício da cidadania e da democracia?

R: É, ela tem um papel bem legal, principalmente no final de semana que tem a escola da família, que eles dão educação fora da escola, tipo espanhol, telemarketing, essas coisas eles tem um meio de cidadania pra dar uma profissão pra gente, isso aqui eles ajudam bastante, ta sempre ajudando a comunidade daqui, não deixa nada de louco, se precisa eles conversam com a escola eles ajudam, tal, a educação é boa tal, falta alguns benefícios aqui na escola, tal, muro essas coisas mas o resto assim de educação tudo a cidadania que eles ensinam pra gente, respeitar essas coisas assim eles ensinam muito bem e a democracia que é o poder da maioria do povo e o pobre é maioria, ai você que as coisas estão erradas. 
Aluno Diego Vieira da Silva

1) Qual o seu nome completo, sua idade e você sempre foi aluno de escola pública ou não?

R: Meu nome é Diego Vieira da Silva, tenho 18 anos e eu estudo na escola pública desde a primeira série e estou cursando o $1^{\circ}$ ano do colegial.

2) Diego, qual o seu conceito de cidadania e democracia?

R: O meu conceito de cidadania e democracia? É a partir da escola, de forma geral... Meu conceito de cidadania tipo que seja...rigorosamente em todos os lugares iguais, tudo igual, tipo assim como preços de mercadorias, direitos, é... o ensino das escolas entendeu, não tôo, muitos funcionários públicos também que nem a polícia coisa assim deveria agir iguais, entendeu. E não deveria ter um certo tipo de discórdia, de uma das regiões, achar que é melhor do que das outras.

3) Então o seu conceito de cidadania e democracia é a igualdade?

R: Isso, igualdade, igualdade total.

4) Diego qual o papel da escola na sua formação para a cidadania e democracia?

R: O papel da escola como cidadão é bom, tipo... é bem rigoroso, porque se agi com cidadão na escola também seria também deveria ser igual lá fora, principalmente para nós alunos ser respeitado dentro e fora em qualquer lugar, assim como os outros e fazer a coisa certa.

5) Você acha que a escola consegue te dar essa idéia, essa noção de cidadania e de prática democrática?

R: A escola consegue sim, consegue porque são muito... a parte da direção também é bastante rigorosa os professores mostram também o que é ser cidadão, ser igual, eleger o governo e pra mim a escola mostra sim. 
6) Diego, você consegue aí fora na comunidade no meio em que você vive agir como cidadão e ser respeitado como cidadão?

R: Consigo, é anda tem parte que eu ajo como cidadão e sou respeitado pelo cidadão normal, como cidadão também, porque eu não uso droga nem nada, né.

7) Você acha que na sua escola e na sua comunidade você tem uma convivência de cidadania de bom nível?

R: Boa entre aspas, né, mas o pessoal pensa em ser cidadão, a convivência pessoal é boa, agora material essas coisas em parte comunitária também num ta bom não, tem desemprego, tem violência, tem droga.

8) O que você acha necessário para que haja respeito à cidadania para que se melhore essa convivência comunitária?

R: Para que melhore? Bom eu não sei assim pegar os pontos pra poder explicar, não tem não! Eu acho que não melhora não.

9) Será que lá onde vive a elite nos Jardins e aqui na periferia o governo vê o cidadão com os mesmos olhos e do mesmo jeito?

R: Não, não porque lá a classe média é bem diferente daqui da classe da periferia, que é pobre e é os modos de lá são bem diferentes daqui, eles não agem como aqui da periferia, não tem aquele certo nível de igualdade.

10) Como você vê essa escola o Aquilino em relação à cidadania e a democracia aqui no bairro onde você mora?

R: Uma escola preparada já para ensinar os alunos, a mostrar aos alunos o que é cidadania e democracia e é uma escola que para cidadania aqui de fora é boa, não tem como ver como uma escola qualquer, é uma escola boa.

11) Sendo você jovem, qual a sua expectativa de futuro como pessoa e como cidadão?

R: Um futuro, bom o futuro de um cidadão trabalhador, né, que esteja em nível 
compatível a qualquer um, e... não sei, ainda não tem como explicar sobre isso não, sobre a minha....ainda não tenho uma noção clara a respeito do meu futuro.

12) E você acha que a escola pode te ajudar a desenvolver essa parte?

R: Essa parte eu acho que sim, pode porque tem professor que, eu não sei se já vem com o ensino assim já preparado pra poder mostrar pro aluno como é que é, entendeu, como se convive nessa parte. Então até lá, até eu terminar meus estudos o ensino médio eu acho que o professor vai mostrando como é, a viver na parte da cidadania e ser cidadão. 
Aluna: Elisângela

1) Qual o seu nome? Sua idade? Você sempre foi aluna de escola pública?

R: Meu nome é Elisângela, tenho 17 anos e sempre fui aluna de escola pública.

2) Que série você está fazendo Elisângela?

$\mathrm{R}: 2^{\circ}$

3) Ensino Médio?

R: Isso.

4) Elisângela, qual o seu conceito de cidadania e democracia?

R: Bom o meu conceito é que assim, precisa..., ta meio difícil ultimamente ter cidadania, conseguir ter cidadania porque eu acho que a gente precisa da boa vontade de todos e é o que falta vamos dizer assim.

5) Quem seria esses todos?

R: A maioria dos alunos.

6) O próprio aluno deveria colaborar com o que?

R: O próprio aluno com o jeito de fazer as coisas aqui.

7) Esse é o seu conceito de cidadania e democracia?

R: Isso. O meu conceito é esse, que todos tem que colaborar.

8) Qual o papel da escola na formação do aluno para cidadania?

R: Acho que não só na matéria, mas também na educação geral é preciso que todos nós também nos envolvamos pra poder dar espaço para os professores, porque os professores, é assim, eu acho que o papel do professor é ...tá ali é passar matéria, mas é conversar com o aluno também, é saber ser amigo do aluno.

9) Você acha que aí fora no meio que você vive, você conseguiria atuar e ser respeitada como cidadã?

R: Em algumas partes sim e em algumas não. 
10) Como você vê essa questão da atuação do cidadão aí na comunidade onde você vive, ele é respeitado ou não?

R: Geralmente não porque os alunos eles não tem..., assim, pelos pais, por alguns sim da para atuar muito bem com a cidadania, mas com algum não porque eu acho que alem de educação na escola eu acho que a educação vem de casa e alguns pais não passam isso pra o filho, acho que é preciso passar uma coisa boa já de casa.

11) E esses pais também seriam respeitados como cidadão eles são respeitados como cidadãos aí fora?

R: Eu acho que não, muitas vezes não, falta de oportunidade acho que tudo isso incluiu para as pessoas não ter uma boa cidadania.

12) O que você acha necessário para que aja respeito a cidadania e para que as pessoas tenham uma cidadania adequada?

R: Boa vontade, oportunidade, uma boa educação.

13) E quem seria responsável por isso?

R: Todos em geral, pais alunos, professores, todos.

14) Você acha que um cidadão que mora lá nos Jardins e outro que mora aqui na periferia, são vistos da mesma forma pelo governo?

R: Não.

15) Porque, você acha que não?

R: Por que o governo, acho... que dá mais oportunidades para as pessoas que vem dos Jardins, é assim a periferia não tem tanta oportunidade, não tem dinheiro, não tem um custo de vida que possa ta não tem uma boa educação já porque eu acho que a gente precisa muito do dinheiro vive muito do dinheiro, a prefeitura, né, o Estado já vê isso no dinheiro, então, já dá mais oportunidade pra quem tem dinheiro, não oportunidade para quem não tem dinheiro. 
16) Você vê problemas aqui na sua comunidade que poderia ser resolvido com a educação ou como uma questão simplesmente de uma educação adequada para a cidadania?

R: Vejo, vejo sim.

17) Quais seriam esses problemas?

R: O uso de drogas, muitas vezes de violência, jovens que muitas vezes não tem oportunidade de trabalhar, e por isso acabam, não que isso seja a maior influencia pro jovem, não, mas uma boa parte delas é a falta de emprego a falta de estudos, muitas vezes, com mais emprego isso podia melhorar.

18) Qual a sua expectativa do futuro como uma pessoa, um ser humano e como cidadã?

R: Tenho, eu tenho uma expectativa que, possa vir a melhorar né porque, que tenha mais empregos, tem mais, o estudo seja melhor, porque muitas vezes a gente precisa e não tem, não pode recorrer muitas vezes a prefeitura porque nunca dá, tem vários projetos que contavam como indo, mais não, nada a ver com uma boa escola, um bom trabalho tudo isso.

19) Tem mais alguma coisa que você gostaria de acrescentar?

R: Não. 
7. ANEXO II - ENTREVISTAS REALIZADAS NA ESCOLA PRIVADA

1) Coordenadora Pedagógica Mônica Regina Maia Martins

2) Professora Eliana Inque

2) Professora Jane Alves Feitosa

3) Professora Sandra Ruccino

4) Aluna Bruna Saraiva de Melo.

5) Aluno Leonardo Lemos.

6) Aluna Geórgia

7) Aluno Tiago Fernandes 
1. Identificação.

O Colégio Augusto Maia é mantido pelo Curso Ideal, que iniciou suas atividades em 1989, com cursos de suplência de $1^{\circ}$ e $2^{\circ}$ graus, na região central de Itaquera, em uma via que dava acesso à antiga estação ferroviária, que mantinha serviços de trens suburbanos.

\section{Histórico}

O Curso ideal chegou a ter mais de 1500 alunos de suplência, o que o estimulou a solicitar autorização de instalação e funcionamento com cursos regulares de $1^{\circ}$ e $2^{o}$ graus e cursos técnicos em nível de $2^{\circ}$ grau. Em 1989 teve seu pleito atendido e começou a funcionar com o nome de Colégio Professor Augusto Maia junto à COHAB José Bonifácio, que havia sido inaugurada no final da década de 70, início dos anos 80 e o governador que a inaugurou a chamava orgulhosamente de a maior do mundo (entre nós, era um psicopata, com megalomanias).

Atualmente o Colégio conta com pouco mais de 1200 alunos e mantém os seguintes cursos: Educação Infantil; Ensino Médio; Normal em Nível Médio, com Habilitação para o magistério em Educação Infantil e Séries Iniciais do Ensino Fundamental e cursos técnicos de nível médio nas áreas de Informática, Gestão, Comércio, Turismo e Comunicação. 
Professora M.R.M.M.,

Coordenadora Pedagógica do Colégio Augusto Maia, habilitada em Educação Artística em 1992, pela Universidade São Judas de São Paulo e com especialização em Psicopedagogia. Começou a lecionar em 1991 e exerce a função de coordenadora desde 1977.

1) Quais são os principais problemas enfrentados pela coordenação?

R: Não existem problemas graves a serem enfrentados em relação à comunidade escolar. Às vezes os alunos reclamam de atitudes dos colegas, mais nada de serio. A rotina é simples e cansativa, professores, estes sim, reclamando que determinados alunos falam muito, pedindo a presença dos pais, fazendo ocorrências, pois temos uma ficha de ocorrência, mas sempre evitando fazer relatórios, no qual nos baseamos para convocar pais. Não adotamos reuniões coletivas de pais e professores, achamos que tanto o aluno quanto o pai é melhor atendido de forma individual, uma vez que nos colocamos permanentemente a disposição deles.

2) Qual o suporte que a escola tern para desenvolver a educação para a cidadania e prática da democracia em relação a Secretaria de Estado e o que ela faz como planejamento dela escola?

R: O Estado já tern muitos problemas com sua própria rede, conseqüentemente quando não atrapalha, por intermédio de seus burocratas, já ajuda muito. A escola procura desenvolver a educação para a cidadania e a prática democrática por si mesma e conta com apoio da mantenedora, o trabalho de seus funcionários que começa com o corpo docente e é realizado com os alunos e os pais dos alunos.

3) Que tipo de trabalho?

R: Alem do trabalho pedagógico junto ao aluno, nós recomendamos aos professores que conheça o aluno. Procuramos avaliar e identificar problemas nos primeiros dias de aulas e para nós e fundamental que se respeite a saúde e os direitos da criança e do 
adolescente, elementos essenciais para uma boa educação. Quando percebemos que o aluno vai mal, normalmente encaminhamos a fonoaudiólogo, medico oftalmologista. psicólogo, psicopedagogos, etc. uma vez que sempre aparece algum caso de hiperatividade, dislexia, discalculia, etc. Sempre que encaminhamos alunos aos especialistas, é após observação e avaliação dos professores e também minha, tenho especialização em psicopedagogia, o que me ajuda muito.

4) Tern retorno este trabalho?

R: Exigimos retorno dos pais, mostramos a eles a ECA e ensinamos como proceder junto ao Ministério Publico, caso eles não tenham recursos para passar a criança pelos especialistas, pois sabemos que a maioria paga a escola com muita dificuldade, realmente realizam sacrifícios para manter os filhos em escola particular. Orientamos inclusive onde encontrar ajuda jurídica, para fazer valer o direito do aluno. É muito difícil ser cidadão na periferia, o desrespeito para com todos é grande, mas procuramos orientar o aluno e seus pais da melhor maneira possível para que ele faça valer seus direitos.

5) E dá certo, sobretudo em relação ao Ministério Público?

R: O Ministério Público tem outras preocupações, não se preocupa muito com o bem estar do povo e em advogar em benefício da sociedade, prefere as luzes da ribalta, seus membros são loucos para aparecer na televisão em questões de pouco ou nenhum interesse popular. Questões populares e de sobrevivência do cidadão honesto, como saúde e educação das crianças na periferia não dão IBOPE (popularidade), mas pressionados inclusive pela defensoria pública para onde encaminhamos as pessoas, acabam funcionando um pouco, ninguém gosta de ser pressionado por pessoa "chata", que conhece seus direitos.

6) E a questão da estrutura familiar?

R: Às vezes aparece alguma criança ou adolescente com um quadro de agressividade, normalmente o problema é familiar, quase sempre são filhos de pais separados, ou mães 
solteiras, mas nós damos a eles o mesmo tratamento que aos outros, chamamos os pais ou pai e orientamos da mesma forma.

7) Se não existe problemas maiores com a comunidade escolar, podemos supor que e uma escola sem problemas?

R: Os problemas são relativos ao meio. Sempre temos denúncia de que traficantes estão nas proximidades, sempre temos um outro caso de aluno envolvido com drogas. por isto exercemos severa vigilância e conversamos muito com nossos alunos. A nossa região é violenta, abandonada pelo Estado, que oferece as instituições, que não funcionam. Aqui é preciso pagar por tudo, inclusive pela segurança.

8) O problema é resolvido com o serviço de segurança mantido pela instituição?

R: Não, nós sempre acionamos a policia, pois a mantenedora paga para ter a presença de policiais, como fazem os supermercados e outras empresas da região, que tem permanentemente viaturas policiais estacionadas em suas portas.

9) O exercício da cidadania na periferia é algo que pode ser desenvolvido?

R: Existem barreiras para tudo na periferia, tudo é muito difícil, não se pode contar com o Estado, nem com suas instituições ou seus agentes se não pagar por isto, mas é possível, é um trabalho de conscientização, que deve ser feito de forma permanente, os resultados podem demorar, mas um dia vão aparecer.

10) Como a escola trabalha a questão dos direitos sociais?

R: Conscientizando os alunos de que os direitos existem, em sendo direitos são universais e não necessidades individuais, que existem dois caminhos que devem ser percorridos diariamente: o político via voto e pressão naqueles que tenham compromissos com a periferia e o judiciário que é o caminho natural para fazer valer a lei. Mas é difícil, muito difícil.

11) O judiciário? 
R: A gente pode achar que judiciário precisa de controle, a gente pode achar que hoje o juiz tem muito poder, a gente pode achar que muitas vezes os juízes são despreparados, a gente pode achar que o cargo de Juiz não deveria ser vitalício, a gente pode achar que os juízes são caras de paus, que mesmo com a imprensa alardeando suas ações, não respeitam a sociedade, não respeitam a lei, fazem a legislação por conta própria, mas não podemos em momento algum esquecer que o judiciário é um poder do Estado e que esta aí para servir a sociedade, a gente tem que criticar e corrigir o judiciário, mas não deixar de usá-lo.

12) A instituição oferece cursos de capacitação para seus professores?

R: Por ter contrato com empresa fornecedora de material didático, ela tem um permanente apoio pedagógico, com cursos ministrados por especialistas em educação.

13) Estes cursos trazem retomo?

R: Difícil responder, obriga-se o professor a participar, mas não se pode obrigá-lo a aprender. Para alguns tem resultados, para outros não, agora independentemente disto, é preciso estar também sempre atento quanto ao que o professor esta fazendo, não deixá-lo desgarrar-se dos objetivos e da filosofia da instituição.

14) Qual a perspectiva de futuro dos alunos?

R: A perspectiva depende da família, nossos alunos em sua maioria são filhos de pais conscientes que realizam sacrifícios, fazem um esforço sobre-humano para manter o filho em escola particular, longe da violência das escolas publicas. Este talvez seja um dos maiores diferenciais entre a escola publica e a privada na periferia. Assim todos eles acabam percebendo que é difícil, que deve haver esforço, mas tem perspectiva de futuro sim. Eu leciono na rede pública, sempre mantive umas aulinhas na escola pública e muito raramente, ou praticamente nunca vi um pai aparecer de forma espontânea para saber alguma coisa do seu filho.

15) Mas a escola pública é esta violência toda? 
R: É normal você chegar lá na escola e não ter aula porque ela foi invadida e assaltada durante a noite. Os alunos da escola pública são mais agressivos, muitos professores têm medo sim e posso dizer que na periferia tem escolas particulares que não pagam sequer igual ao Estado, embora a maioria pague no mínimo igual e poucas pagam um pouco melhor e mesmo assim os professores preferem lecionar nas particulares, onde não sofrem riscos de agressão. Mas existem também exageros. 
Professora Eliana Correia da Silva Inque

Licenciada em Letras pela Universidade de São Paulo, começou a lecionar na instituição em 1981. Leciona até hoje, em todas as séries do Ensino Fundamental e Médio, as seguintes disciplinas: Língua Portuguesa e Redação como preparação para o trabalho.

1) Você pode traçar um paralelo entre o aluno de ontem e o aluno de hoje? A educação de ontem e a educação de hoje?

R.: Aluno de ontem: recebia informação rotulada, em todas as disciplinas; era avaliado com rigor e as avaliações visavam a conteúdos extensos que, em tese, dariam a dimensão do seu intelecto. Educação cobradora, quanto mais enérgica, mais preparava para a vida. Poucos tinham acesso e os que tinham acesso temiam a escola, principalmente a escola pública: o aluno do ESTADO era olhado com respeito, pois se diferenciava dos outros, intelectualmente.

Aluno de hoje: teoricamente tem uma escola com as portas abertas à sua espera, com planejamentos escolares visando à sua integração ao meio, através de projetos interdisciplinares; as informações que recebe devem baseadas no aspecto qualitativo; as avaliações devem observar suas competências em diversos momentos da aprendizagem e não somente através de uma prova escrita ou exame. Digo teoricamente, porque na prática, a maioria das escolas apesar das mudanças, dos avanços, ainda pratica a educação à moda antiga: privilégio da quantidade de informações; avaliação unilateral, aulas com conteúdos isolados sem a preocupação de trazer para o momento da aula, situações da vida do aluno. O aluno ainda é avaliado através de notas declaradas ou ainda "notas disfarçadas" (letras/conceitos), que visam principalmente à conduta do aluno pelo senso comum: "é disciplinado", “é respeitoso", “é atencioso" , "trouxe as lições”, “tem o caderno em ordem”. Nos 
conceitos não são revelados os porquês da "desatenção", “indisciplina”, "desrespeito". Quem avalia ainda é o todo-poderoso. Professor e Escola mais "benevolentes", mais "compreensivos" ou mais "adequados às novas propostas podem escrever histórias diferentes para um mesmo aluno que tenha sido observado num "contexto conservador", onde o educador é o sujeito de todo o processo.

2)Você que lecionou dentro do período do regime autoritário e leciona agora no regime democrático e sabe que sempre esteve colocado na fala oficial o objetivo de Educação como formação da cidadania e para a pratica democrática, percebeu mudanças na relação Educação e Cidadania? Existe hoje um maior ou menor interesse do Estado, com ações positivas, sérias e corretas em efetivamente preparar o cidadão?

R:O que caracteriza o cidadão é a sua participação na vida social, nas decisões que dizem respeito ao desenvolvimento da comunidade e do país. É preciso que todo cidadão tenha seus direitos respeitados e seja cumpridor dos seus deveres. O regime autoritário pregou a educação como ato de depositar, de transferir, de transmitir valores e conhecimentos; a educação refletia a sociedade opressora; nessas condições, o educador representava o detentor do saber e o educando, o que nada sabia; a consciência crítica ocupava uma posição inferior. A escola, hoje, tem propostas voltadas diretamente para o exercício da cidadania, exercício este que deve ser iniciado na própria escola. O Estado oferece as ferramentas que são a escola e o professor. Entendo que é participando que se aprende a participar e, observando por este ângulo, vejo que as propostas de hoje são interessantes, bem intencionadas, porém pouco praticadas e quando praticadas deixam a desejar quanto ao estímulo do exercício consciente da cidadania, mas isto é uma questão de gestão e administração escolar, consciência e preparação do professor. As escolas públicas, 
por exemplo, procuram administrar projetos com finalidade social, mas essas mesmas escolas não permitem que seus alunos discutam o plano da escola, o plano do curso, os métodos didáticos, as avaliações, o desempenho escolar, contrariando princípios da própria Secretaria da Educação. O Estado, teoricamente, mostra maior interesse em preparar o cidadão: as leis estão aí, disponíveis e prontas para serem trabalhadas...

3) Você não leciona em escola pública, mas conhece a educação pública. Como você vê a ação da escola pública na formação da cidadania? E como você vê a ação da escola particular?

R: Na escola pública, muitos projetos preocupados com a "inclusão" do aluno na vida em comunidade; projetos que visam a um aproveitamento do mundo conhecido pelo aluno. Não raro observamos projetos excelentes que escoam pelo ralo, pois não têm sequiência dentro da própria escola - habilidades artísticas, artesanais, de liderança são colocadas de lado por falta de interesse dos gestores escolares ou dos docentes ligados à instituição, mas o Estado leva a culpa. As tentativas de trabalhar a preparação para a cidadania consciente são e serão sempre válidas, pois não é possível conviver com a idéia de adultos irresponsáveis, sem iniciativa e com baixa auto-estima. Na escola particular, vejo que há mais preocupação com o domínio do conhecimento das matérias escolares - o preparo para o mundo competitivo. Isso não quer dizer que a questão cidadania fique de lado dentro de seus contextos; o procedimento é outro; via de regra fica embutida nas pesquisas escolares, nas discussões em sala de aula; nos procedimentos administrativos; muitas escolas trazem nos seus planos projetos grandes visando exclusivamente à consciência de valores: solidariedade, preservação do meio-ambiente; reciclagem, preservação da fauna, segurança, primeiros socorros. No entanto, na periferia, a família que busca 
uma escola particular, geralmente quer garantias de excelência no conhecimento adquirido pelo aluno e quer retornos concretos em termos de conteúdo e a escola vai perpetuando $\mathrm{o}$ modelo tradicional $\mathrm{e}$ às vezes não preparando $\mathrm{o}$ aluno adequadamente para a participação na organização da vida política do país.

4) Existem, alguns colegas que acham que hoje realmente está muito melhor que ontem e neste ritmo amanhã deverá estar melhor do que hoje. Você vê assim?

R: A pesar de não concordar com isso, sou otimista. O processo democrático é sempre benéfico; pode caminhar lentamente, mas é o ideal. Na prática, diria que vivemos um momento de reflexão sobre os valores sociais, políticos, econômicos, éticos e talvez não estejamos transmitindo isto corretamente para o aluno. Observo que a sociedade, ainda que individualista, desigual, exploradora, admite a discussão dessas mazelas no contexto escolar e aguarda por resultados que evitem a reprodução dessas desigualdades e condições sociais injustas. Nesse ponto, lembraria que a escola deve ser vista como o fator que faz a diferença e que modifica a sociedade para melhor; isso sempre, a qualquer tempo e é necessário estar sintonizado com o cotidiano, trazer a discussão das questões de impacto e repercussão social postas nos meios de comunicação para a sala de aula. Discutir as propostas no parlamento, as propostas do Executivo, o como o Judiciário e o Ministério Público encaram as questões que são vitais para o cidadão e que passam por eles e sobretudo insistir no conceito que o Estado democrático tem respeitar a minoria, mas tem que refletir a vontade da maioria e ser aquilo que a sociedade quiser que ele seja, que o Estado não é um ente ou um ser que decide por si só o que quer ser e como deve ser a sociedade. Lamento, no entanto, que a lentidão que observamos nos grandes centros, passa a ser um processo de paralisia em regiões menos favorecidas e mais distantes: muitos terão de conviver por muito tempo, 
ainda, com situações humilhantes, indignas, protagonizadas pela falta de sintonia entre o sentimento do povo e os poderes do Estado.

5)Em uma periferia como esta você vê carência de equipamentos sociais e percebe alguma ação concreta do Estado para alterar o padrão e a qualidade de vida desta população ou percebe que tudo caminha bem e que todos realmente estão bem atendidos? Acha que alguma coisa está errada? Em caso positivo, como deve ser feito para melhorar?

R.: Muita carência em todos os níveis. Reforçaria aqui a tendência da sociedade desigual e injusta. Não temos escolas públicas que visem à profissionalização, nas proximidades; isso é previsto na lei. A cultura escolar no nosso bairro limita-se às escolas e uma ou outra biblioteca pouco recheada de livros; há pouca divulgação das atividades culturais na redondeza; a moradia....Nos demais segmentos, há falhas sérias: faltam centros de convivência para crianças, jovens e adultos; a saúde é um outro problema: fila de espera, quem necessita de tratamento mais especializado normalmente passa semanas esperando por uma consulta; as áreas mais centrais estão em melhores condições, porém, não têm como acomodar todos aqueles que carecem de atendimento; a urbanização das vilas mais distantes é um outro fator preocupante, pois o saneamento básico é precário; a violência é uma realidade inegável, inclusive nas escolas públicas que se equipam como verdadeiros presídios e têm que abrigar no seu interior o produto do meio, que é o aluno violento ou alheio a qualquer responsabilidade social. As ações do Estado são lentas e muitas vezes ineficazes; muita teoria e pouca prática. Os trabalhos mais eficientes são os desenvolvidos por entidades organizadas pela própria comunidade, ou instituições como igrejas, por exemplo.Para melhorar, vejo que a comunidade naquilo a que se propõe carece de recursos financeiros, recursos materiais, além mão-de-obra 
especializada; os voluntários nem sempre estão qualificados para prestar os serviços para os quais se apresentam ou são designados. O Estado e a comunidade devem ser parceiros; é necessário investir nos agentes sociais de maneira mais eficiente, é necessário preparar melhor os agentes do Estado que existem e prestam serviços na região, é preciso mostrar à comunidade o caminho da mudança, que tem o seu eixo básico na educação.

6) Uma vez que a cidadania implica em diretos sociais, como você analisa esta questão da periferia? Vai bem ou vai mal? Em quais segmentos?

R: Sob o ponto de vista dos direitos, vejo que a questão da periferia é intranqüila: o indivíduo tem consciência de sua "condição desigual" mas acha "natural" viver assim, ou seja, a disposição para a mudança é adiada ou esquecida, pois o próprio indivíduo ainda considera o Estado o responsável pela sua condição e fica esperando um governo salvador e a sua consciência cidadã fica relegada a um segundo plano e a sua baixa auto-estima o leva a aceitar a sua inferiorização. Sendo assim, passa a ser "normal" andar em coletivos superlotados e pagar caro pela passagem; ter o veículo danificado nos buracos das avenidas mal conservadas, não freqüentar as ruas devido ao risco de assaltos, aceitar uma escola desprovida de equipamentos ou com alto índice de faltas dos professores; para a periferia conviver com o descaso não é novidade na saúde, segurança pública, lazer, moradia, educação...

7) Você acha possível educar para o exercício da cidadania com resultados positivos?

R: Sim.

8) O que você faria como sugestão para se atender este objetivo?

R: O objetivo da escola é possibilitar que o aluno se desenvolva e sinta-se preparado para o exercício da cidadania. Na medida em que podemos elaborar e executar os 
nossos projetos de vida somos pessoas melhores. Penso que educar para a cidadania exige um esforço conjunto que deve incluir o corpo escolar, a família e a sociedade. O fator família é um entrave, pois vivemos momentos de desagregação familiar: muitos alunos não vivem com o pai e a mãe; convivem em dois ambientes e são espectadores de discussões, agressões, isso quando não são os próprios alvos dos incidentes. A escola aliada à comunidade seria o primeiro passo; observo que aqui a política do "faz-de-conta" é absurda - conheço muitos profissionais que têm em suas escolas uma gestão dita democrática e, na verdade, os assuntos de interesse geral acabam ficando de lado para que apenas "aquele" que em tese é o dono da verdade tome decisões. Currículos adequados à realidade do aluno e que permitam que suas experiências de vida sejam utilizadas, sem menosprezar o lado intelectual moro em frente a uma escola pública famosa na região e fico triste com o que constato: as aulas ficam de lado em favor de atividades repetitivas e que, por vezes, estimulam a violência; vejo que muitos alunos em nome da "democracia", dizem o que querem, desafiam os superiores, depreciam os professores e se acomodam naquilo que julgam ser o correto dentro da escola: 'vocês estão aqui para me servir e resolver o meu problema'; não raro, a direção tem que refazer a pintura, as beiradas dos muros que já são altos, pois o prazer de uma parcela dos alunos é agredir. Isso não é preparo para a cidadania. Mas a falha é certamente da escola. Planos de aula que envolva atividades voltadas para o grupo e não para o individual, através de fórum de debates, pesquisa, exposições, visita a instituições diversas, campanhas com finalidade social. Professores mais bem preparados e estimulados, inclusive monetariamente, para exercer a sua função; o bom professor é o que participa das transformações sociais, é o que preza a sua autonomia; é o que passa para o aluno a noção de liberdade e independência. Enxergar o potencial do 
aluno e empurrá-lo para frente e para o alto com firmeza e segurança, sem "dedos nos narizes", chamando para a responsabilidade, ouvindo e trocando experiências, eis o que classifico como imprescindível para o bom desempenho da função. A escola que realmente busca caminhos também não pode ter preguiça: planos, currículos, projetos, tudo isso a qualquer tempo pode e deve ser discutido, alterado e adaptado se a necessidade assim o exigir.

9)Você sente retorno em uma ação sistemática da educação voltada para a cidadania? R:É claro que há trabalhos sérios. Temos muitos exemplos de experiências bemsucedidas com a comunidade participando direta ou indiretamente e a auto-estima do aluno melhorando. Estive analisando que o sucesso dos trabalhos normalmente ocorrem quando a escola atua como agente facilitador do desenvolvimento intelectual conjugando essa função com o trabalho concreto voltado para as necessidades do meio e que isso exige um esforço pessoal de cada profissional engajado nos projetos. Eu não posso pensar no trabalho isolado desta instituição, para falar da realidade da periferia eu tenho que pensar toda a periferia, você pode servir de exemplo ou modelo, mas considerando o universo é só um passo. A nossa realidade, no entanto, permite dizer que estamos ainda muito longe de atingir essa meta de provocar alterações no meio. Temos muitos problemas econômicos e isso talvez seja um obstáculo. As mudanças requerem investimentos e estes requerem recursos financeiros bem direcionados. O resultado é que muitas crianças estão fora da escola, a evasão escolar e a reprovação ainda são significantes, a qualificação do professor também é um caso a ser discutido, não basta ter um grade contemplada por filosofia e sociologia, ao lado de História e Geografia e outras disciplinas básicas, bem como um planejamento, é preciso saber se o professor habilitado que ministra a disciplina sabe como trabalhar a disciplina; a escola precisa de recursos 
materiais além de gizes e apagadores. Tudo isso tem um preço...Mas não devemos ser pessimistas; o trabalho sério é sempre bem-vindo e sempre começa com um primeiro passo.

10) Você acha possível o desenvolvimento integral do cidadão sem consciência cidadã da comunidade? Fora o processo sistemático da educação, existe apoio do Estado para o desenvolvimento de uma consciência cidadã? Quais outras instituições governamentais poderiam dar uma contribuição positiva e, atualmente, quais ajudam e quais atrapalham?

R: Evidentemente que não. O desenvolvimento integral do cidadão é fruto do preparo correto para a cidadania. $\mathrm{O}$ cidadão consciente respeita os direitos dos outros e fazse respeitar. Já sabemos que em última análise é a sociedade que educa e que a escola é o setor formal dessa educação. Sendo assim, a família seria a primeira a participar do processo de formação da cidadania, mas pelas características de nossa população, em sua grande maioria de descendentes de migrantes e graças ao período do regime autoritário a consciência de cidadania e da prática democrática, ficou relegada a um segundo plano, o migrante queria primeiro sobreviver. Em se tratando do apoio do Estado, o conjunto das ações de todos os segmentos seria o ideal: saúde, economia, segurança, justiça, meio-ambiente, educação, aliados a organizações não-governamentais, igreja, associações de bairro, fundações, empresas privadas. Com a colaboração de todos, tudo seria mais fácil. A palavra chave para a periferia neste momento é solidariedade. Hoje, o trabalho visando à consciência cidadã está nos planos de ação dos Estados e municípios de todo o Brasil; teoricamente é uma grande preocupação para todos; as lideranças mal intencionadas, mal assessoradas, mal preparadas ou despreparadas é que são o grande problema - muita burocracia; verbas inexistentes, mal distribuídas ou mal 
administradas. A cidadania, para muitos, é "bandeira política" ou a oportunidade para vantagens escusas. 
Professora Jane Alves Feitosa

Licenciada em Letras pela Faculdade Paulistana, cursando atualmente complementação em Pedagogia e começou a lecionar em 1998, leciona em todas as séries do Ensino Fundamental e Médio, as seguintes disciplinas: Língua Portuguesa e Redação como preparação para o trabalho. Leciona também na escola pública, onde é professora efetiva.

1) Você pode traçar um paralelo entre a escola particular e privada no que tange à educação para a cidadania? Entre o aluno da escola pública e da escola privada?

R: Na escola pública a educação para a cidadania é vista dentro do conceito de objetivo geral, desde projetos propostos pelo próprio Governo, como escola da família, até os oferecidos em oficinas, como o projeto água, nos quais os professores participam de encontros e ou palestras e devem propagar o conteúdo na escola em que lecionam. Existem também projetos propostos pelo próprio corpo docente, nos quais eles são livres para criar e para por em prática. O aluno acaba recebendo uma gama de informações, vindas de diversos lados e se sente envolvido com a questão. Já na escola privada, além de disciplinas específicas a cidadania é trabalhada também de forma interdisciplinar, a questão é vista pelos diversos professores de forma abrangente, sempre pensando em formar um cidadão com sentimento crítico sobre o mundo em que vive, sua realidade, seu contexto.

2) Você sabe que sempre esteve colocado na fala oficial o objetivo de Educação como formação para a cidadania, pergunto: percebeu mudanças na relação Educação e Cidadania após a publicação dos Parâmetros Curriculares Nacionais, no pós 1996? Existe interesse do Estado, com ações positivas, sérias e corretas em efetivamente preparar o cidadão? 
R: Acredito ainda ser muito cedo para avaliações severas, estamos ensaiando os nossos primeiros passos, as escolas estaduais e municipais estão ainda implementando projetos, como CCEU, Escola da Família, Telecurso, EJA, hoje, como uma modalidade incorporada aos sistemas. É claro que os parâmetros curriculares auxiliaram, houve ações positivas, sérias e corretas, escolas particulares procuram dar respostas, colocar os direitos e conceitos para que se exercite a cidadania, mas a caminhada é longa e andamos pouco.

3) Como você vê a ação da escola pública na formação da cidadania e prática da democracia? E como você vê a ação da escola particular?

R: A escola pública se empenha de forma superficial, abandonou-se o conteudismo, o "decoreba", passou a falar em interdisciplinaridade, mercado de trabalho, mas há muitas falhas, desde continuidade do projeto, até o resultado final. Já a escola particular vê de forma mais abrangente e efetiva, pois coloca um projeto com continuidade e buscando um resultado final, o aluno acaba apreendendo a essência básica da vida cidadã e da democracia.

4) Existem alguns colegas que acham que hoje realmente está muito melhor que ontem e neste ritmo amanhã deverá estar melhor do que hoje? Você vê assim?

R: Em alguns aspectos sim. Quando se fala em interdisciplinaridade, cidadania, formação crítica, os números do SARESP, ENEM, UNESCO, mostram que efetivamente são necessárias mudanças em alguns aspectos no que tange ao conteúdo ensinado, a forma como é ensinado, por exemplo, em relação à cidadania, não basta você ter filosofia na grade curricular e um planejamento que exige que seja dado o Sócrates, por exemplo, é importante entender o Sócrates na formação da cidadania, e ai depende de como o professor vai ministrar Sócrates, e isto na maioria das vezes escapa do controle da coordenação e aí estaremos 
falando também em preparação do professor, que é outra questão, alias questão grave na escola pública, mas que existe também em menor proporção na escola particular, da periferia bem entendida. O próprio professor acaba sendo produto do meio e ainda existe a dita amizade com o mantenedor ou diretor, etc que faz com que o incompetente permaneça, achando que está agradando... É preciso repensar a disciplina em sala de aula, sobretudo na escola pública, que é a maior queixa dos professores, que acabam não tendo instrumentos de controle, mas acaba sendo de novo um problema de preparação do professor e ou mesmo de gestão conjuntural da escola, ou seja, uma ação típica de direção. Na escola pública isto é muito difícil, na escola particular isto é mais bem trabalhado.

5) Em uma periferia como esta você vê carência de equipamentos sociais, e percebe alguma ação concreta do Estado para alterar o padrão e a qualidade de vida desta população, ou percebe que tudo caminha bem e que todos realmente estão bem atendidos? Ou acha que alguma coisa está errada e o que deve ser feito para melhorar?

R: Não percebo ação efetiva do Estado, as escolas têm um péssimo nível de ensino, as drogas e a violência tomaram conta da periferia, são constantes em todos os lugares. Não há locais para recreação, pouquíssimas bibliotecas. O que deve ser feito é um grande investimento em qualidade de vida, mas aí adentramos outro campo, pois o problema, obviamente, da qualidade de vida só pode ser resolvido com uma melhor distribuição de renda.

6) Uma vez que cidadania implica em direitos sociais, como você analisa está questão na periferia? Vai bem ou vai mal em quais seguimentos?

R: Vai mal em todos os segmentos, a pessoa em sua maioria não sabem quais são realmente seus direitos e, portanto não os exigem. Melhorou um pouco os 
conhecimentos dos direitos do consumidor, a partir do Código do Consumidor e do Procon, mas ainda é muito pouco, porque a justiça é muito lenta e a impunidade acaba sendo a regra.

7) Você acha possível educar para o exercício da cidadania e da prática democrática com resultados positivos?

R: Sim, o aluno realmente pode se tornar um ser mais crítico, conhecedor de seus direitos, nós estamos tentando isso aqui e diminuímos um pouco está prática do conteudismo, que os pais sempre acabam nos cobrando.

8) O que você faria como sugestão para se atender este objetivo?

R: Por exemplo, na minha disciplina modificar o ensino da gramática em língua portuguesa, pois enquanto haver professores ensinando praticamente só proparoxítona, paroxítona, dissílaba, sujeito, predicado, etc. haverá uma forma de opressão elitista e falhas. A preocupação maior é ensinar a gramática textual, voltada para a prática, para a vida real, para a compreensão da realidade. Cada um em sua área buscar levar o aluno a entender a praticidade do que ensina em seu cotidiano, levá-lo a uma visão crítica do universo em que vive, o que certamente vai levar a uma educação que construa realmente sua cidadania.

9) Você sente retorno em uma ação sistemática da educação voltada para a cidadania?

R: Sim, claro que não espero $100 \%$ de retorno por parte dos alunos, mas em alguns teremos um retorno que poderemos considerar bom, percebemos isto, a evolução ao longo do ano letivo.

10) Você acha possível o desenvolvimento integral do cidadão sem consciência cidadã por parte da comunidade? Fora o processo sistemático da educação, existe apoio do Estado para o desenvolvimento de uma consciência cidadã? Quais outras 
instituições governamentais poderiam dar uma contribuição positiva e atualmente quais ajudam e quais atrapalham?

R: Muito difícil quase Impossível se desenvolver sem consciência cidadã da comunidade. O estado apóia uma consciência cidadã, que não o incomode. Dá algum apoio à escola e não recorre a nenhum outro instrumento, você não vê apoio em nada, nem dos organismos policiais, nem do Ministério Público e muito menos da Justiça e é isto que torna a situação difícil. Nós temos instituições como a FEBEM, que é uma vergonha, por outro lado a omissão do Estado tem propiciado o surgimento de instituições não governamentais, mas não bastam Associações Amigos de Bairro, Greenpeace, etc, a periferia precisa de muito mais, precisa de uma forte presença do Estado, precisa de investimentos que somente o Estado pode fazer e de precisa de mecanismos de controle sobre os poderes do Estado, que a própria sociedade precisa desenvolver com o apoio público, como contribuição para a formação da cidadania e da consciência democrática. 
Identificação.

Professora Sandra Ruccino

Licenciada em Historia pela UNICASTELO, tem 22 anos de magistério, começou sua carreira no Magistério como professora das series iniciais do ensino fundamental (professora primaria) na época do regime militar. Leciona Historia, Geografia, Sociologia e Filosofia na instituição pesquisada desde 1998.

Entre vista:

1) Você pode traçar urn paralelo entre o aluno de ontem e o de hoje?

R: O aluno de ontem não tinha o direito de questionar e hoje em dia alem de questionar ele também faz suas reivindicações, hoje a educação esta voltada para a formação de urn cidadão consciente e critico, pois fazem parte de uma sociedade mais democrática.

2) Como você vê e trabalha seu aluno na formação da cidadania e da prática da democracia?

R: Trabalho na escola particular e na escola publica e meu trabalho esta voltado para conscientizar os alunos de maneira que ele possa contribuir de modo positivo dentro desta nova realidade que hoje vivemos. Na escola publica o programa "A escola da Família", tem dado oportunidade para a comunidade e ate mesmo jovens que não estudam a participar das atividades voltadas para o lazer e também para o aprendizado de algumas profissões como pedreiro, diversos tipos de artesanato, entre outros e acredito que isto tem dado resultado, isto é cidadania participativa. A escola particular possibilita trabalhar mais a questão de formação acadêmica, o histórico, origem e evolução do direito e definição dos direitos, de forma que os alunos tenham uma visão que possa contribuir de forma positiva para o exercício da cidadania. São realidades diferentes, embora tenhamos também alguns alunos com famílias desestruturadas, o normal e que ele tenha estrutura familiar e 
perspectiva de futuro, na escola publica o universo é outro, mas se trabalha a cidadania atendendo outras necessidades. O aluno da rede particular você o prepara para o futuro e o da rede publica precisa de urn atendimento imediato, para questões imediatas e você faz o que e possível fazer, o que acontece é que muitos professores e mesmo diretores (gestores) não estão preparados, não conseguem fazer a sua parte, mas eu entendo que a ação do Estado é positiva.

3) Existem alguns colegas que acham que hoje realmente esta muito melhor que ontem e neste ritmo amanha devera estar melhor do que hoje? Você vê assim?

R: Pior e melhor em relação a que? Do ponto de vista político a democracia possibilita articulação, organização, cobrança, o que em longo prazo pode ter evolução e do ponto de vista social, com o fim da repressão todos os problemas apareceram. Eles já estavam ai, mas havia a truculência do Estado e as pessoas não percebiam, o Estado talvez ainda seja truculento na periferia, mas você pode denunciar e lutar contra esta truculência e com o tempo a sociedade poderá controlar o Estado, as perspectivas são outras. O que o pessoal reclama e do aparente excesso de direitos sem deveres de minorias, reclamam da indisciplina dos alunos, etc. $\mathrm{O}$ mundo é outro, as coisas mudaram, a censura ditatorial com o tempo sendo substituída pela do bom senso, não se pode ficar clamando por censura dos órgãos de comunicação; e isso e enquanto as coisas não se assentam vão parecer que estão bagunçadas. Não podemos falar de pior e nem de melhor, temos que talar de novos tempos, de novos conceitos e nos prepararmos para isto.

4) Você sabe que sempre esteve colocado na fala oficial o objetivo de Educação como formação para a cidadania, pergunto: percebeu mudanças na relação Educação e Cidadania apos a publicação dos Parâmetros Curriculares Nacionais, no pos 1996? Existe interesse do Estado, com ações positivas, sérias e corretas em efetivamente preparar o cidadão?

$\mathrm{R}$ : Eu acho que o governo faz o que acha correto, conforme a leitura que ele faz dos 
problemas da periferia e acredito que ele também em sua representação o admite como tendo alguma deficiência, confunde a pobreza com deficiência e reconhecendo o morador da periferia como urn subcidadao. Por exemplo, a policia não pode ser educada com este morador senão ela acabara sendo vitima da violência deste morador, assim o governo não a entende como violenta e desrespeitosa e sim como enérgica. Portanto, é com este tipo de ótica que o poder publico procura desenvolver as ações para a cidadania e é claro que não vão de encontro às necessidades reais do cidadão pobre. Assim, cabe a nós educadores, conscientizar o cidadão de que ele é igual sim e mostrar aos governantes que pobreza não e deficiência, que o cidadão pobre merece o mesmo respeito; que a energia da policia é violência mesmo. Eu acho que só a cobrança de forma organizada vai fazer o governo ter uma representação adequada de cidadania, com igualdade entre todos. Enquanto isto o governo acha que esta fazendo sua parte e que os projetos e investimentos que faz atende o povo.

5) Você sente retorno em uma educação sistemática da educação voltada para a cidadania?

R: Qualquer ação em educação traz retorno, não se pode esperar e retorno imediato, mas traz sim e vamos admitir que o povo entenda o que são direitos sociais e comece a ir ao ministério publico e entre com ações exigindo atendimento na saúde, o governo tem como suprir estas necessidades? Logo, é interessante para o governo ensinar o aluno que em sendo um direito o cidadão pode exigi-lo através do judiciário? E disponibiliza meios para que isto ocorra? Um dia será assim e o próprio governo sabe disto e ele mesmo deverá prover os meios para que assim seja.

6) Você acha possível o desenvolvimento integral do cidadão sem consciência cidadã da comunidade? Fora o processo sistemático da educação, existe apoio do Estado para o desenvolvimento de uma consciência cidadã? Quais outras instituições governamentais 
poderiam ajudar com uma contribuição positiva e atualmente quais ajudam e quais atrapalham?

R: Sem consciência cidadã da comunidade é impossível. Acho que me alonguei muito nas respostas anteriores e acabei por extensão respondendo a questão do apoio do Estado. Eu poderia falar aqui em defensoria publica, delegacia especializada para atender o cidadão em suas relações cotidianas, em que a policia é necessária para fazer valer o direito do cidadão, como por exemplo, você fazer uma queixa de propaganda enganosa e a polícia ir até o local e apurar o fato, no ato, ou você denunciar uma transgressão no trânsito e a polícia ir apurar e outras pequenas coisas deste tipo, isto iria acabar com a impunidade, começaria com coisas pequenas e chegaria nas maiores, a lei seria respeitada e por extensão os direitos dos cidadãos, etc.

9) O que você faria como sugestão para se atender este objetivo de educação para a cidadania?

R: Neste momento não tenho como responder isto, porque isto implica em desenvolver um projeto que iria abranger a participação de diversas instituições, mas eu digo em princípio que eu unificaria as ações do Estado na periferia em um único órgão.

10) Uma vez que cidadania implica em direitos sociais, como você analisa esta questão na periferia? Vai bem ou vai mal em quais seguimentos?

$\mathrm{R}$ : Acho que por ter falado muito já respondi isto nas questões anteriores, mas vou resumir, ele anda de acordo com o ritmo de compreensão que o cidadão faz de seu próprio direito e de como o Estado acha que deve agir com alguém com insuficiente entendimento do que seja o seu direito. Os direitos sociais um dia serão cobrados, mas hoje só podemos falar da omissão do Estado e do próprio cidadão por falta de educação e conseqüentemente conhecimento dos seus direitos. 
Aluna: Bruna Saraiva de Melo - $3^{\text {a }}$ Série E. Médio.

Aluna do Colégio Augusto Maia desde a $5^{\text {a }}$ Série do Ensino Fundamental.

Idade: 17 anos

Trabalha como professora de Inglês e de Recreação em Escola de Educação Infantil, desde os 14 anos.

1) Qual é o seu conceito de cidadania e de democracia?

R: Que toda pessoa deve cumprir seus deveres para poder exigir seus direitos.

2) E quais são esses direitos do cidadão?

R: Direito à moradia, à educação, à saúde, a você ser livre p'ra escolher qualquer partido político, a forma de governo, liberdade de expressão. Acho que deve ser isso.

3) Você sabe conceituar estes direitos?

R: Direitos sociais, civis e políticos.

4) Você acha que é possível exercer a cidadania na periferia onde parece ser tudo tão difícil?

R: As pessoas nem tem noção de cidadania, de que possuem cidadania, nem conhecem né, não correm atrás, já se fosse de uma classe mais alta já teria noção e poderia exigir do governo, mas como não tem noção, não conhecem e se não conhecem não praticam e como você mora na periferia, você acaba sendo tratado igual aos outros, como uma pessoa sem consciência de nada, como se não fosse uma cidadã.

5) Você acha que a vida na periferia é um pouco mais difícil ou é igual e normal como em qualquer outro lugar?

R: Acho que é mais difícil ainda e que a escola pública, que é maioria na periferia é que acaba não ajudando, fica mais complicado, porque todos acabam passando 
pela escola, mas nem todos saem com conhecimento de cidadania, pelo que vejo dos meus amigos a escola pública acaba não preparando direito, então você tem um que sabe e cinqüenta que não sabe.

6) Já que você falou, essa noção de cidadania, você desenvolveu onde?

R: Aqui na escola mesmo, a gente tem as matérias né, e aí o professor explica pra gente, a gente teve oportunidade de conhecer as leis tudo e conhecer nossos direitos e deveres também, deu uma instrução pelo ensino mesmo, procurou sempre ensinar o que é democracia para a gente saber e perceber que na prática não tem povo coisa nenhuma no poder e que a gente tem que mudar isto.

7) Você, no seu conceito, acha, que existe respaldo, apoio do governo para que as pessoas exerçam a cidadania.

R: O governo fala muito em apoio e eu acho que se tem é muito fraco. Talvez o governo não queira que nós conheçamos nossos direitos p'ra gente não cobrar dele. Entendeu?

8) Você sabe que nos parâmetros curriculares e mesmo na lei de diretrizes e bases, existe a definição de objetivo de que a educação no ensino fundamental deve ser voltada para a cidadania?

R: Eu não sabia.

9) Você acha que existe um esforço de educação para a cidadania?

R: Pelo menos aqui, na escola onde eu estudo, eu acredito que sim, em outras escolas acho que não né.

10) Aqui você acha que tem?

R: Aqui tem matérias como ética, sociologia, filosofia, voltados para a cidadania.

11) Você acha que a escola dá noção de cidadania, mas o governo não dá o retorno que o cidadão precisa para exercer a cidadania? 
$\mathrm{R}$ : Eu acho que sim, porque você acaba sabendo que o direito existe, mas quando as pessoas correm atrás dele, na polícia, na justiça, não o encontram, os órgãos do governo não ajudam.

12) O que você acha disto?

R: Eu acredito que na periferia as condições são mais precárias, em lugar mais rico deve funcionar, eu acho que é uma discriminação econômica.

13)Se fosse possível o que você faria para que pudesse realmente exercer seus direitos, o que seria necessário?

R: Acho que o governo deveria dar mais assistência, para todos os lugares, não só para o centro, para a periferia também e acompanhar mais de perto para ver se as leis estão sendo seguidas, cuidar melhor para que não se soltem tantos criminosos, como esse jornalista que matou a namorada, porque se um pode matar e ficar solto, então todo mundo pode matar e acho que é por isso que tem essa história de mata-mata todo dia na televisão; ver como está o ensino, se ele está mesmo voltado para a cidadania, porque muitas vezes o que está no papel não se cumpre. 


\section{Aluno: Leonardo Lemos}

18 anos

Aluno de escola particular desde a $3^{\circ}$ série. Augusto Maia.

Servente de Pedreiro (trabalha com o pai).

1) Você sabe que a educação deve ser voltada para a cidadania, qual o conceito de cidadania?

$\mathrm{R}$ : De certa forma eu sei na teoria o que seria cidadania que se ensina na escola, mas a atuação da cidadania eu sei e que eu cuido das melhores formas de atuar como cidadão, mas eu sei que as pessoas hoje em dia não têm esse conceito e não agem para estar recebendo isto também.

2) Aqui na escola você recebeu uma educação voltada para a cidadania?

R: Recebi. Lá fora é que você não vê. Não vejo as pessoas atuando com isto ou até mesmo agindo direito.

4) O que você acha de receber uma educação para cidadania e sair lá fora e ter esta dificuldade para exercê-la?

$\mathrm{R}$ : Eu acho que isto tem uma certa influência do Estado, eu acho que se fosse mais rígido, as pessoas não estariam assim, eu vejo como uma coisa muito aberta, meio perdida. Acho que o Estado não dá suporte suficiente para as que as pessoas consigam praticar. Isto é uma ausência de ação do Estado para poder junto com as pessoas, porque se tem exemplo, é mais fácil as pessoas aprenderem, mas do jeito que vem ocorrendo hoje, com corrupção, fica meio difícil.

3) Qual é o seu conceito de cidadania e democracia?

R: Cidadania e democracia eu acho que é aquela pessoa que tem direitos e deveres em prol da sociedade. A gente tem que praticar o bem, querer ajudar o próximo e a si mesmo, sem querer prejudicar as pessoas. E a gente conscientemente não querer 
estes atos que vem ocorrendo ai.

4) Que tipos de atos?

R: Assaltos, roubos, enganação por parte das pessoas e corrupção de políticos e de autoridades em geral.

5) Que atos seriam estes que o cidadão deveria praticar?

R: Ajudar a comunidade, não só por fazer algo por ela, mas sim por ser uma boa pessoa.

6) Você falou em ausência do poder efetivo do Estado, onde você sente isso?

R: Na questão do policiamento, hoje em dia a gente pode ver que a cidade sente muito em relação a isto, parece que a polícia não sabe o que está fazendo e o poder político é que está gerando grandes dificuldades para o Brasil.

7) O que você faria para melhorar o Estado e a formação escolar?

$\mathrm{R}$ : Eu acho que primeiramente não adianta a gente querer modificar de fora para dentro. Eu acho que deveria começar numa educação dentro da escola, começar com as crianças menores. Eu tenho amigos que estudam em escolas públicas e dificilmente tem aulas e quando tem é pouca coisa, então não tem como você forçar, mas fazer com que as pessoas compreendam um pouco sobre isso, não tem aulas e quando tem as pessoas vão só marcar presença, é difícil, vai aprender como?

8) Qual sua perspectiva de vida?

R: Concluir meus estudos trabalhar e me formar e constituir família. 
Aluna Geórgia Sarai -17 anos

$2^{\circ}$ Ensino Médio

1) Qual o seu conceito de cidadania?

R: O conceito de cidadania que eu tenho para mim é bem resumido, é o direito que você tem de exercer seus deveres e direitos, direitos e deveres do cidadão.

2) Você sempre estudou em escola particular?

R: Sim, mas nesta escola em entrei este ano, eu sou de outro Estado, eu vim da Bahia.

3) Uma metrópole do tamanho de São Paulo é diferente de Salvador, como você vê o exercício da cidadania aqui em São Paulo?

R: Eu não vou dizer que o exercício é impossível, mas é difícil, pelo tempo que estou aqui e pelo que tenho visto é que é muito difícil, as coisas aqui são difíceis.

4) Quais são as dificuldades?

R: A política né, é muito grande, nos caso o Estado, o governo, não tem condições de suprir as necessidades, é muito grande, a população...é tudo muito grande...

5) $\mathrm{O}$ que você acha que acaba sendo prejudicado, qual direito acaba não sendo assegurado?

R: Direitos à segurança, ao trabalho, ao lazer, uma boa educação e finalmente os direitos para você saber enfrentar esta situação da metrópole e saber cobrar.

6) A educação que você recebeu não ensinou você a desenvolver a sua cidadania?

R: A escola aqui tem disciplinas que ensina isto, como sociologia, filosofia, ética, que ensinam os direitos mesmo, mas não é só isso, o Estado não ajuda, ele falta, não procura suprir.

7) E na Bahia, você teve uma educação voltada para a cidadania?

R: Muito pouco, só uma coisa geral, não era assim coisas específicas. 
8) O que você acha que seria necessário para que realmente pudesse haver o exercício da cidadania?

$\mathrm{R}$; Eu acho que todas as escolas deveriam aderir este tipo de educação aqui da escola, que procura ensinar os direitos e como usar os direitos seria mais fácil se tudo mundo entendesse isso, seria melhor para todo mundo, e a questão do Estado procurar ver o que falta e procurar suprir. 
Tiago Fernandes

1) Thiago, qual a sua idade?

$\mathrm{R}: 18$ anos

2) Você já está trabalhando? Em que você está trabalhando?

R: To trabalhando, na área de programação.

3) Tiago, você sempre foi aluno de escola particular?

R: A partir da $5^{\mathrm{a}}$ série.

4) Qual é o seu conceito de cidadania e de democracia?

R: Cidadania e democracia são meios que fazem você cumprir com seus direitos e deveres perante a sociedade.

5) A sua formação escolar ajudou você a desenvolver o conceito de cidadania e democracia?

R: A escola tem a base pra fazer você ser um cidadão, ou seja, mostrar o que é cidadania e o que é democracia.

6) Você recebeu essa informação?

R: Recebi, posso até não dominar direito a coisa, mas recebi sim.

7) Ela te deu então noções para que você pudesse exercitar a cidadania?

R: Dentro dessas noções ela também mostra o lado crítico e te mostra que o Estado é ausente e que os poderes acabam não sendo seus não, como deveriam ser.

8) Como você caracterizaria essa ausência do Estado?

R: A ausência do Estado é que existe um poder alheio, que manda por aqui e ele não demonstra para a sociedade que pode enfrentar este poder, vai ver que é um poder oculto, ele impõem, mas, num, num sabe que tipo de cidadão ta querendo realmente, o cidadão também não vai atrás dos seus direitos, não faz o Estado assumir o controle na periferia. 
9) Ou seja, não dá um suporte para o exercício da cidadania?

R: Isso, cidadania é só no papel.

10) E sendo esse cidadão, se você fosse fazer um pleito aqui, o que você pleitearia, o que você iria exigir mais, por exemplo, do Estado, hoje aqui na periferia de uma grande metrópole, que é São Paulo?

R: Hoje na periferia é totalmente comprovada a ausência do Estado, vamos dizer que o Estado é o poder nominal, todo mundo sabe que o Estado é o poder, só que na periferia ocorre poderes alheios também, exemplo de facções. O Estado não está a parte? A polícia que está a parte, mas não faz nada porque o Estado é ausente, não obriga seus funcionários a desempenhar seus papéis.

11) Se o Estado é ausente, onde ele falta com a função, o dever dele?

R: O Estado ele.. Não impõem aquilo que os cidadãos tem... Como necessidade de segurança de ir e vir tranqüilo para o trabalho, para casa, para o lazer; nos setores educação, saúde, e no caso trabalho, existe muito desemprego, que prejudica as famílias.

12) Ser cidadão na periferia será que é diferente de ser cidadão numa região de maior poder econômico?

R: Muito diferente,.. que o Estado pode estar ausente, mas dependendo do lugar onde você esteja de acordo com esse poder econômico você vai ter uma base de apoio bem maior, você vê a polícia na rua e sente que ela está lá para proteger o cidadão e não para atrapalhar. Eu escolhi estudar numa escola particular, entendeu, porque eu moro em periferia desde que eu nasci, e eu sei que a escola particular teria essa base pra eu ter a noção do que é cidadania e não ser vítima do próprio empregado do Estado. 
13) Dentro desse conceito de cidadania, você tem os direitos sociais. Você acha que o Estado atua em função dos direitos sociais do cidadão na periferia?

R: Direito social? O cidadão tem liberdade de expressão, só que essa liberdade de expressão nunca é ouvida. A liberdade de expressão foi criada em torno de uma democracia, só que essa democracia também não é cumprida, os poderes do Estado não agem pensando no que o país precisa.

14) Você acha possível que a educação um dia será tal como está nos Parâmetros curriculares, você acha que pode melhorar a situação da periferia na educação me que acabará sendo realmente dirigida para a cidadania?

R: Só melhorará a educação para o próprio cidadão, se ele souber o seu conceito de cidadania a partir da própria educação, hoje ele aprende o conceito só que ele sai na rua e esse conceito não é feito, porque não se pratica a democracia. É preciso entender a democracia e os poderes do Estado, que são poderes do povo, mas o povo na realidade está fora do poder, que deveria ser dele e que ele dá para outros através do voto. A democracia representativa não está sendo representativa de ninguém, o cara chega ao poder e o poder passa a ser dele, o Juiz presta um concurso e o poder passa a ser dele, está tudo errado...

15) E onde ele deveria cobrar isso, o poder como uma coisa dele?

R: junto ao Estado!

16) Como?

R: Mudando a democracia e praticando os seus direitos democráticos de cidadão e organizando de novo tudo que está aí.

17) E ele está preparado para isso?

R: Não.

18) Então como resolver? 
R:É difícil, mas tem que ter um jeito ou está tudo perdido, a gente tem que encontrar o jeito.

19) Pelo que você sente, vive e conhece por meio dos seus colegas existe uma diferença entre a educação particular em questão de cidadania e a educação publica?

R: Totalmente, uma diferença muito grande porque todo mundo escuta o que é cidadania, mas cada um recebe essa informação e passa para outras pessoas de outra forma, eu não sei se o professor da escola pública está melhor ou pior preparado, mas sei que na escola particular existe espaço para se cobrar dos professores e existe matérias que tratam praticamente só disto.

20) A escola publica trabalha com essa questão?

R: A publica até trabalha, só que o Estado tem uma função bem maior na escola publica, por exemplo, a preocupação é só oferecer a própria escola.

21) Os seus colegas que estudam em escolas publicas tem esse mesmo senso, esse mesmo conceito que você tem?

R: Não, por isso que eu escolhi estudar em escola particular. 
PAIS DE ALUNOS E DEMAIS MEMBROS DA COMUNIDADE

1) César Augusto Maia;

2) Antonio Rosa;

3) Marcelo Campo Belo;

4) Agnaldo de Jesus de Souza;

5) Edmilson Tavares de Lima; e

6) Arivaldo Canteiro. 


\section{7) Senhor César Augusto Maia.}

Pai de aluno e morador de Itaquera há 50 anos.

1) Qual sua idade?

R: Meia quatro (sessenta e quatro)

2) Qual a função que o senhor exerce?

R: Algumas. Manutenção, serralheiro, soldador, transportador escolar.

3) Há quanto tempo o senhor mora na periferia de São Paulo?

R: Mais ou menos cinqüenta (50) anos.

4) Como o senhor definiria ser cidadão na periferia de São Paulo?

R: É ser um qualquer, ser cidadão aqui em São Paulo é ser um qualquer, não tem cidadania, não existe mais cidadania, se você não tem emprego e não tem como sustentar seus filhos, não é um cidadão, só é cidadão na hora de votar. Certo?

5) Qual o seu conceito sobre cidadania e sobre democracia?

R: No meu conceito eu...os dois não existem. : É ser um qualquer, ser cidadão aqui em São Paulo é ser um qualquer, não tem cidadania, não existe mais cidadania, se você não tem emprego e não tem como sustentar seus filhos, não é um cidadão, só é cidadão na hora de votar. Certo?

Como o senhor acha que se pode mudar esta situação de uma democracia apenas nominal? O que seria possível fazer para mudar isto?

R: Nominal, gostei da definição... olha... para mudar isto tem que mudar tudo. Começar de cima, a podridão vem de cima, tem que ser de cima mesmo, começando pelos juízes, pela legislação que já é bem antiga né, Código Penal, tudo isso, tá tudo parado há muito tempo, há mais de cinqüenta anos (50) tá tudo parado. Então...começando tudo outra vez, mudar todo esse povo que tá no poder, tirar todos eles, começar tudo outra vez. Começar um novo processo, 
porque não teve democracia até agora, começar um processo novo, com pessoas novas, reorganizar a sociedade para se ter democracia.

6) O que o senhor poderia dizer sobre a violência na periferia, de forma geral e aquilo que todos comentam a violência policial.

R: A violência já está no ar e piora ainda depois dos indultos que se dão para os presos e eles não retornam mais. Todo preso recapturado, é tudo...a maioria do indulto, eles não voltam mais, são presos soltos pela policia. Então é difícil de se ter uma segurança, não tem segurança, o povo é totalmente inseguro, sujeito ao bandido, só isso.

7) Houve em 2004 uma pesquisa datafolha que demonstrou que mais de $50 \%$ da população tem medo da polícia, da polícia militar, não se pesquisou a policia civil, o que o senhor acha desta pesquisa?

R: Pesquisa certa! Eu mesmo tenho medo dos dois, eu tenho medo dos dois, porque os dois são corruptos, mais a civil é mais corrupta é lógico, mais os dois são corruptos, raras são as exceções.

8) Então a polícia não é solução é problema para a periferia?

R: A Polícia é problema para a periferia, a polícia sempre foi problema para a periferia, sem segurança, totalmente à mercê dos bandidos. Eu fui fazer queixa de que roubaram o meu carro, ficaram perguntando qual o meu nível de escolaridade e se eu tinha seguro, quando em disse que não, nem perguntaram onde foi que eu fui roubado e como eram os bandidos que me assaltaram, eu tentava falar e eles nem tomavam conhecimento, me trataram que nem cachorro depois que eu disse que não tinha seguro.

9) Como pai de aluno, como o senhor vê o reflexo da educação em relação aos seus filhos? 
R: Meus filhos tem que ser colocados numa escola particular porque a da Prefeitura e do Estado os marginais estão no portão. Polícia não tem nenhuma, você não vê polícia, você só vê polícia na padaria, nas escolas você não vê nenhuma, só vê nas padarias, lanchonetes, fazendo segurança, bico...na escola não tem polícia, então é melhor ainda a particular.

10) Na realidade o senhor já está fazendo também uma crítica à escola pública?

R: Exatamente, a escola pública não tem segurança, a polícia só está lá de enfeite, apenas passa com o carro da Ronda Escolar, mas não tem preocupação, ninguém está atuando.

11) Se a democracia é o povo no poder e o senhor disse que aqui não tem democracia e que é necessário para reorganizar, por onde o senhor iniciaria esta reorganização da democracia?

R: A reorganização teria que trocar todo pessoal que está no poder atual e recomeçar é um processo demorado... mas tem que ser assim... ou então é sem condição...cada vez pior.

12) Pelo que o senhor disse o judiciário está sendo colocado como um dos fatores que agrava a situação de violência na periferia?

R: É o principal, é o principal, se você...a lei é só para pobres então não adianta...porque está ai as CPIs que ninguém resolve nada vira tudo em pitiça (pizza), sanguessuga é um exemplo, o dinheiro que apareceu no meio da eleição, fica tudo por elas, ninguém comenta mais, o povo fica no esquecimento, o povo tem memória fraca. Eu queria ser Juiz, ser marajá, ganhar vinte e quatro mil por mês...que legal heim, é o povo que paga...e você ainda ganha por fora e pouco importa se quem sofre é o povo. 


\section{Antônio Rosa}

1) Qual a sua idade, profissão e há quanto tempo o senhor mora na periferia de São Paulo?

R: Eu tenho 49 anos de idade e tenho trinta anos de São Paulo e sempre morei na Zona leste, tenho várias profissões, mas exerço atualmente a função de manutenção geral.

2) Qual é o conceito que o senhor tem de cidadania, democracia e como é ser cidadão na periferia?

R: Ser cidadão na periferia é a gente fazer por onde se dar bem com os outros cidadãos. Agora para mim cidadania e democracia é ótimo, são boas.

3) O senhor tem dificuldade em exercer a cidadania na periferia, o que o senhor acha do Estado, a forma como os poderes do Estado são exercidos?

R: Não, não tenho dificuldades, eu começo por mim, como bom cidadão em relação, criei uma boa cidadania perante as outras pessoas.

4) O seu conceito de cidadania é ser um cidadão perante as outras pessoas, mas em relação ao Estado e aos poderes do Estado como o senhor vê a cidadania?

R: Em relação aos poderes do Estado alguns trabalham bem outros não, alguns chegam com vontade de trabalhar mas já tem aqueles outros que atrapalham e acaba ficando entrando ano saindo ano a mesma coisa do passado não muito bom.

5) O que senhor acha da questão da violência na periferia?

R: Bom a violência, né, a violência tem vários aspectos, a violência do assalto, assassinato, roubo, etc. eu acho que a segurança pública deveria ser mais rigorosa, deveria ter mais condições das pessoas caminhar legal pelas ruas, para ir para o trabalho, para ir para a escola, mais tranqüilo, o poder que cuida deste detalhe é o judiciário não é? 
6) Não, o executivo é quem deve oferecer segurança, a competência do judiciário é julgar, ele deve condenar ou não quem comete os crimes.

R: Veja bem, até para as pessoas se locomover dos seus lares, para ir trabalhar falta condições, a pessoa já sai de casa estressada, por pouca coisa a pessoa já parte para a violência, ninguém mais respeita ninguém, por causa das drogas também né, ai você não sabe o que fazer.

7) Qual seria a sua sugestão para alterar este quadro?

$\mathrm{R}$ : Eu creio que principalmente no caso dos adolescentes deveria oferecer mais cursos gratuitos e oferecer mais oportunidades de emprego, para que ocupem mais a mente deles durante o dia com coisas úteis.

8) Pelo que o senhor está dizendo a solução seria a educação?

R: Com certeza, a educação mais rígida para que o adolescente de hoje, o jovem não fique perdido por ai.

9) Como o senhor vê Educação na periferia?

R: Eu vejo o ensino público como algo muito fraco e acho a escola particular mais forte. Mas acho que a educação é muito importante para melhorar a vida de todos. 
Marcelo Campo Belo

Comerciante (farmacêutico) e pai de aluno.

1) Senhor Marcelo qual a sua idade e há quanto tempo o senhor mora na periferia?

R: Eu tenho 38 anos e moro há 38 anos na periferia.

2) Eu gostaria de saber qual seu conceito de cidadania e democracia?

R: Cidadania é onde todos têm o direito de receber o melhor, de procurar o melhor para si e receber o melhor do Estado e democracia é o seu direito de ir e vir e procurar também o melhor, procurando os seus direitos e direitos iguais para todos.

3) Eu sei que o senhor tem uma atividade comercial na periferia, conseqüentemente o senhor tem uma experiência de convivência com a comunidade periférica, nesta relação do senhor com a comunidade como o senhor vê a questão da violência e como o senhor vê a ação do Estado na periferia?

R: Você não ação efetiva do Estado na periferia em relação à violência, eu como comerciante...você fica nas mãos dos bandidos. Quem gera a violência na verdade na periferia acaba sendo os próprios policiais amedrontando as pessoas, sendo quem protege, estou falando de periferia mesmo, quem protege, na questão física das pessoas, são os próprios bandidos que mandam no local. É assim que eu vejo e é assim que eu vivo na farmácia na Cidade Tiradentes.

3) Em 2004 houve uma pesquisa do datafolha para apurar como a população se sentia em relação à polícia e o foco foi a policia militar, foi em toda a cidade de São Paulo e 54\% da população respondeu que tinha medo da polícia e achou que ela era a causa da violência, o que o senhor acha da pesquisa?

R: Eu acredito nesta pesquisa, pelo que você vê e pelos meus clientes e até por mim, as pessoas tem medo da polícia e muito medo da polícia, não confiam na polícia. 
Saber pelo menos na periferia que existe uma condição de... eu posso entrar neste local se os bandidos deixarem, então você sabe que existe coisa errada e eles mostram o tempo todo que está tudo errado. Então o pessoal não confia na polícia e eu também não confio.

4) E nos demais poderes do Estado, por exemplo, como o senhor vê o judiciário?

R: Não, não confio no judiciário. Eu vejo várias injustiças, vejo presos saindo na hora que quer, vejo rebeliões o tempo todo na televisão e nada sendo feito, vejo um acidente de carro, onde o causador está fora da cadeia. Quando eu preciso, demora, eu mesmo já fiz ações e isto demora e você acaba desistindo porque a justiça demora é morosa e tudo é contra a democracia, tudo é contra a legalidade, tudo é contra a lei, parece que tudo é ao contrário.

5) O senhor acha que o judiciário ou o membro do judiciário que é o juiz não cumpre a Lei?

R: Ele pode cumprir a lei, mas não para todos, pelo que eu vejo. Ele cumpre a lei pelo que eu vejo, para quem tem dinheiro, para quem pode pagar, para o restante ele vai bem moroso, bem devagar, até que as pessoas desistem no meio do caminho e ai se fala que ele tentou cumprir, mas não deu porque as pessoas desistem pela morosidade.

6) A democracia deste jeito então funciona?

R: Não, não funciona, no meu jeito de ver democracia, não. Os direitos tem que ser iguais para todos e não está funcionando, está tendo para alguns, para a minoria.

7) O que o senhor colocaria como sugestão para corrigir esta distorção?

R: Mudar o judiciário, mudar as leis, leis mais rígidas, tirar o poder total do judiciário, tirar o poder total dos mandantes do nosso Estado, porque se continuar assim sempre vai continuar...Tem que mudar as leis, tem que mudar as leis para que os 
juízes não tenham tanta autoridade, tem que mudar as leis para que os advogados possam ser vigiados no que estão fazendo, para que a lei ande, sei lá, tem que mudar muita coisa no sentido judiciário. Enquanto continuar deste jeito só quem tem um bom advogado e só que tem o poder da lei nas mãos (que é o Juiz) e sabendo de como ela é flexível, vai ganhar. Enquanto isto a população vai sempre perder.

8) Neste quadro como o senhor vê a ação da educação em relação à dinâmica de vivência na periferia?

R: A educação é importante, você pode ver pelo que acontece no comércio. A partir do momento que você começa a instruir as pessoas, no próprio comércio, a dar idéia de como elas podem agir, as pessoas mudam, você sente no tratamento, o respeito, o respeito com o próximo...a partir do momento que você passa isto... e isto acontece na educação, numa escola a partir do momento que você passa a demonstrar que as pessoas tem direito e como elas podem utilizar isto, você pode mostrar qual o poder dela. É lógico que as vezes você passa uma visão hipócrita de acreditar ainda no judiciário, mas as pessoas começam a aprender a cobrar mais e ser respeitadas, a educação vem para isto, para dar uma visão ampla das coisas, enquanto você tem uma visão bitolada, não anda.

9) Então a reorganização da sociedade necessariamente passa pela educação e a reorganização da própria democracia só é possível pela educação?

R: Na minha opinião é, só é possível através da educação, só a educação pode mostrar o caminho. 
Agnaldo de Jesus de Souza

Segurança e pai de aluno

1) Eu gostaria de saber qual o nome a idade e a profissão do Senhor?

R: Agnaldo, 39 anos, casado e profissão segurança.

2) Há quanto tempo o senhor mora na periferia?

R: Olha, aqui na região de Itaquera eu já to há 28 anos, sou nascido e criado em São Paulo.

3) Qual o conceito ou a noção que o senhor tem de cidadania e de democracia?

R: É hoje, hoje com a situação que o país ta vivendo a gente sei lá, em algum aspecto eu acho que cidadania está deixando a desejar, em todos aspectos, o desemprego é grande, a fome o desemprego, a desumanidade, se as coisas fossem ..sei lá...do jeito que eu penso que seja o certo uma pessoa não podia morrer de fome e outra pessoa morrer de congestão, uma pessoa tem dez casas alugada e outro mora debaixo de um viaduto, quer dizer que eu acho que hoje aqui não tem perspectiva de melhora nenhuma, acho que é daqui para pior mesmo porque o próprio ser humano está acabando com tudo.

4) O senhor tem alguma sugestão para mudar este quadro?

R: Olha com sinceridade, não vejo mudanças não, do jeito que chegou acho que ninguém consegue consertar mais não, acho que só Deus mesmo para poder dar algum resultado para esse povo.

5) Então na realidade, para o senhor a democracia não funciona?

R: Com certeza, acho que não, porque os direitos são de poucos, a maioria sofre com isso, não tem funcionado não.

6) O que o senhor acha da instituição escolar e da educação na periferia?

R: É outro ponto, a educação é para poucos hoje em dia, porque tanto o Estado como 
a Prefeitura não dá segurança, o pai manda a criança para a escola pública com o coração apertado e o ensinamento já não é de primeira, a educação é para poucos, porque os próprios professores da rede pública, é por assim dizer não estão dando de tudo de si porque não tem retorno nenhum dos alunos, dos pais e os alunos não tem o material básico para freqüentar a escola, então quer dizer que os pais não encaminham os filhos e os professores também não estão motivados a dar o ensinamento adequado e quer dizer que é daí para pior mesmo e a educação hoje é para poucos.

7) Como o senhor vê a violência na periferia?

R: Agora apertou mesmo, porque nós tamos vendido, a corrupção impera mesmo e a...nós tamos vendido para a marginalidade, hoje em dia a violência tá imperando mesmo, é só corrupção, o dinheiro está falando mais alto.

8) Está corrupção é de quem, dos políticos, do Estado, dos policiais, do executivo, do legislativo, do judiciário é da polícia, onde o senhor vê o foco da corrupção?

R: Nesse caso ai eu acho que...polícia ta corrompida com certeza e é o poder legislativo e o judiciário, cada um tá mordendo a sua fatia, mas a pior parte mesmo é a polícia que ta vendida para a marginalidade. 
Edmilson Tavares de Lima

Técnico de informática e pai de aluno

1) Qual a sua idade e profissão?

R: Tenho 43 anos e sou Técnico em Informática.

2) Há quanto tempo o senhor mora na periferia?

R: Há quarenta e três anos.

3) Então o senhor sabe bem o que é viver na periferia?

R: Sim, claro, conheço o dia a dia da periferia.

4) Qual é o seu conceito de cidadania e democracia?

R: Cidadania e democracia, uma depende da outra, estão interligadas, tem democracia, tem cidadania, a democracia é o princípio da liberdade, o direito de ir e vir, fazer ou não fazer.

5) Como é exercer a cidadania na periferia?

R: É difícil, a discriminação é grande. O modo de vestir, o modo de socializar, relações de todo o tipo, morar na periferia, só de falar que você mora na periferia você já tem um grau de credibilidade menor, é uma batalha constante para você mostrar que é um cidadão e tem que ser respeitado.

6) O processo democrático na periferia é semelhante ao processo democrático do cidadão dos jardins?

R: Não, não é, gostaríamos que fosse, mas não é, lá o exercício é pleno, aqui você tem que conquistá-lo ponto a ponto, todo dia.

7) Então o senhor diria que não somos tratados como cidadão?

R: É difícil explicar isto, porque é o que se sente, alguns aqui até se sobressaem, mas é isto, somos sub-cidadãos.

8) Como o senhor vê a ação do Estado na periferia? 
R: Bom, é, algumas entidades do Estado em alguns pontos do Estado tentam até fazer a inclusão dos cidadãos da periferia, como se faz em outras regiões, mas o Estado está negligenciando, os recursos são subsidiados, são recursos falhos, não são bem colocados e isto deixa o Estado capenga com relação a isto.

9) Como o senhor vê a violência e a segurança na periferia?

R: Violência, sobrevivência, o mais forte realmente ainda sobrevive, a violência continua uma coisa que não é bem vista pela sociedade, ou seja a periferia não tem todos os recursos que teria a segurança na zona sul ou de regiões centrais da cidade então deixa muito a desejar, aqui ainda manda o mais forte.

10) Existe uma pesquisa feita pelo datafolha feita em 2004 sobre a polícia, na qual 54\% da população de toda a cidade tinha medo da polícia militar, mas a pesquisa não abrangia a polícia civil, o que o senhor acha desta pesquisa?

R: Bom, com relação à polícia civil eu acredito que ela está também dentro desta margem, porque não é visível por não usar uma farda e é difícil de identificar, mas há uma insegurança e total falta de confiança nas polícias.

11) Então a população não confia nas polícias?

R: Não, e ela até tenta confiar, mas quando percebe que a vida dela vai ser colocada em risco porque não se sabe que caráter tem o policial...A população tem que desconfiar, o dia a dia mostra. Tenha um encontro com a polícia e você vai sentir a diferença entre ser um cidadão da zona sul e um da zona leste, ou seja, você vai ver o tratamento.

12) Então na prática a democracia e a cidadania não funcionam?

$\mathrm{R}$ : Eu posso dizer que sim, que não funciona, tem até o esboço de funcionar, mas não funciona.

13) Qual seria o papel da educação para interferir na realidade da periferia? 
R: Sem educação vai ser difícil mudar a mentalidade e fazer com que o cidadão da periferia mostre o seu poder de decisão e de concepção das coisas. 


\section{Identificação.}

Arivaldo Canteiro.

Bacharel em Direito pela Universidade Brás Cubas, advogado militante e também licenciado em História pela Unicastelo. Lecionou na rede pública no final da década de 70 e início da década de 80, afastou-se do magistério por ter ingressado na Polícia Civil, por aproximadamente vinte anos, retornou em 2002.

1) Eu gostaria de saber sobre a história em que o mantenedor do Colégio Augusto Maia, quase foi preso por desacato á autoridade por não chamar o Delegado de doutor e se não tivesse chamado um colega que mostrou ao Delegado que não era doutor e se não fosse professor, teria certamente sido agredido e preso. Isto era um procedimento comum?

R: Foi na década de oitenta do século passado, ele foi queixar-se de que sua escola tinha sido invadida e quase acabou preso, o procedimento era comum e eu tenho dúvidas de que tenha mudado muito.

2) Isto foi na época da ditadura, hoje seria diferente?

R: É difícil responder. Primeiro temos que considerar que o autoritarismo faz parte de nosso processo histórico. Quando a polícia mostra saudosismo do período ditatorial, ela está dizendo que as práticas do período eram corretas e está sendo coerente com o autoritarismo típico de nossa sociedade. Pegue um policial antigo, ele não se conforma até hoje com o governo Montoro e com o respeito aos direitos humanos. A violência era para impor a Lei? Não, para estar acima dela, para ser como Deus, dono de todo o poder para o bem ou para o mal.

3) Felizmente isto mudou?

R: Eu diria que isto não vai mudar nunca, a policia acha que o poder é dela e não do Estado, ela pode achar que pode usar da violência, que para ela não é violência é 
método de trabalho.

4) Trabalho? Em benefício de quem?

$\mathrm{R}$ : Eu disse que ela acha que é um método de trabalho e o benefício, não é para a sociedade é para ela mesma, a corrupção é baseada inteiramente na violência, no direito à violência que a polícia tem.

5) E o controle que deve ser feito pela própria autoridade administrativa do Estado, do Ministério Público e o Judiciário?

R: O cidadão hoje e também as instituições é fruto, ou melhor, nasceu de uma geração pós-golpe, onde o grande lema era "proibido proibir". Portanto a noção de hierarquia e disciplina ficou distante. Durante o golpe militar a manipulação do povo, o desrespeito ao universo legal gerou este leviatã social de nossos dias atuais. Todo se transformou em superficial. Hoje o corrupto e pouco importa de qual poder ou instituição sabe que não será punido, assim cada autoridade ou membro de um poder, sente-se como um barão medieval junto aos servos da gleba e assim nada se respeita. Tem até advogado que acha que é autoridade e sempre que pode procura intimidar o povo.

8) Você sabe que sempre esteve colocado na fala oficial o objetivo de Educação como formação da cidadania, percebeu mudanças na relação Educação e Cidadania após a publicação dos parâmetros curriculares nacionais, no pós 1996? Existe interesse do Estado, com ações positivas, sérias e corretas em efetivamente preparar o cidadão? R: Não. O discurso é um e a prática é outra, há falhas estruturais de paradigmas e não se vislumbra um arquétipo.

9) Em uma periferia como está você vê carência de equipamentos sociais, e percebe alguma ação concreta do Estado para alterar o padrão e a qualidade de vida desta população, ou percebe que tudo caminha bem e que todos realmente estão bem 
atendidos? Ou acha que alguma coisa está errada e como deve ser feito para melhorar?

R: Volto a citar a manipulação da opinião pública pelos dois poderes, Legislativo e Executivo, é necessária a seriedade e o trabalho.

10) Uma vez que cidadania implica em direitos sociais, como você analisa está questão na periferia? Vai bem ou vai mal em quais seguimentos?

R: Direitos são conquistados e preservados não existe forma de dar-se o direito gratuitamente de mãos beijadas. Vai mal em todos segmentos.

11) Você acha possível educar para o exercício da cidadania com resultados positivos?

R: Da forma político-social atual essa crença é um engodo, uma falácia.

12) O que você faria como sugestão para se atender este objetivo?

R: Reforma política-administrativa com uma legislação condigna, só então uma reforma educacional adequada, seria um país com direitos, deveres, obrigações, e volto a insistir na conquista que é o resultado do querer, de sentir necessidade. $\mathrm{O}$ Poder Legislativo que vive em constante estado feérico e o Poder Judiciário emperrado e marcado como na Ilha da Fantasia, pelo costume de chefete que cada patrício nosso possui, quando assume um cargo, não trabalha para o coletivo, mas como autoridade sente-se dono da verdade absoluta, senhor da formalidade e tanto pior para a sociedade.

12) Como assim, senhor da formalidade?

$\mathrm{R}$ : Eu vou dar um exemplo prático, que ocorreu no último concurso para Professores do Ensino Básico II do Estado (PEB II). Professores licenciados em Matemática com Registro do MEC em Física, Professores licenciados em Filosofia, com Registro MEC em História, Professores Licenciados em Ciências Sociais, com Registro MEC em Geografia, com amparo legal na Lei 4021/61 e 5692/71 e atos 
administrativos como Portarias Ministeriais, não tiveram seus direitos de fazer o concurso e tomar posse respeitados. Tinham mais que direitos adquiridos, tinham direitos consumados. $\mathrm{O}$ ato ou resolução que excluía o direito destes profissionais lecionarem foi baixado pelo Secretário, as disposições do concurso foram realizadas pela Diretoria de Recursos Humanos, baseados em atos ou Resolução do Senhor Secretário da Educação e, portanto o Edital do Concurso excluía os professores, aplicando a retroatividade da Lei (absolutamente inconstitucional, a lei não pode retroagir para prejudicar o ato jurídico perfeito e o direito adquirido). Pela legislação de hoje, estes professores não estariam habilitados, mas estavam pela legislação antiga. Havia Resoluções do Conselho Nacional de Educação, desde 2003, reconhecendo o direito destes profissionais e apesar disto a Secretaria de Educação do Estado não reconheceu este direito. Muitos advogados impetraram ações em favor de seus clientes, contra a autoridade coatora imediata, que não lhes deu posse, contra o diretor da escola e tiveram seus direitos respeitados, alguns impetraram contra o Senhor Secretário da Educação. Conheço um caso que a defesa da Secretaria da Educação disse que o Senhor Secretário não era parte e que o ato de coação não era dele. O Promotor Público manifestou-se na ação dizendo que o requerente tinha direito e que cabia a ação contra o Senhor Secretário e deu embasamento jurídico ao que dizia, à luz do Direito Administrativo. O Juiz indeferiu o pedido do professor dizendo que o Senhor Secretário não era parte. O Professor recorreu e novamente teve seu pedido negado em segunda instância, porque o colegiado, aqui quem julga é um colegiado, disse que o professor tinha que ter entrado com a ação contra o Diretor da Escola e não contra o Secretario da Educação, que na prática exarou atos tornando obrigatória a prática dos Diretores de Escola de não dar posse aos professores. O Senhor Secretário é parte sim, mas 
veja o absurdo, por uma questão ritual da justiça, os senhores juízes não julgaram o direito, não entraram no mérito, o cidadão é vítima de uma violência que se prática atropelando a Constituição da República e seu direito não é reconhecido por uma questão meramente ritual. E a vida do cidadão? Isto parece não ter importância para os poderosos e arrogantes membros do judiciário. Porque julgar o direito? É mais fácil reconhecer a ilegitimidade passiva, pois a Lei em seu ritual prevê esta figura. A forma é mais importante do que o direito e a vida? Pergunto, isto não é uma Ilha da Fantasia, em que mundo estão os senhores magistrados? É possível a democracia? Magistrado que expede ordem de busca e apreensão de criança de 3 $\operatorname{anos}^{56}$, em que mundo está? E a sociedade tolera, até quando? Apenas para concluir a questão, circula nos meios jurídicos que os senhores magistrados não tem se dado ao luxo de ler os processos, parece que os processos são lidos, analisados e despachados pelos técnicos judiciários, pela assessoria dos senhores juízes, que eles apenas assinam os despachos. Pergunto, para que magistrados? Não seria melhor conselhos comunitários? O controle do judiciário é necessário e urgente, tenho a impressão que haveria mais justiça. Conseqüentemente é preciso reformar tudo.

\footnotetext{
${ }^{56}$ Fato amplamente noticiado pela imprensa, na qual Magistrado na cidade de Serrana, região de Ribeirão Preto, expediu ordem de busca e apreensão de criança de 5 anos, por ter atirado pedra (quando tinha 3 anos) que acertou um carro que passava pelo local. A policia cumpriu o mandato, a criança e seu pai foram conduzidos por força policial à presença do Juiz. Um funcionário do Fórum de Serrana, que prefere não ter o nome divulgado, diz que não existe ilegalidade no ato. "O juiz fez uma intimação para o garoto e o responsável irem a uma audiência e eles não foram localizados no endereço. Por isto foi expedido um mandado para que o menor e o responsável fossem levados à presença dele. Isto é de praxe. Agora que o pai $\mathrm{e}$ o menor estiveram aqui e foram advertidos o caso está encerrado", afirma.

O pai do menino e o garoto compareceram na presença do juiz e, durante a audiência, Edson Calbelo diz que mostrou a sua indignação. "Eu fiquei revoltado porque eles não prendem bandido e mandam prender uma criança? O juiz me disse que tudo era um mal entendido e que não tinha mandado prender o meu filho. Eu falei para ele que o camburão foi lá em casa buscar o menino e que os policiais queriam prendê-lo. Não fizerem isto porque minha irmã não deixou",

Noticia disponível no site http://www.juspodivm.com.br/noticias/noticias_1213.html
} 